\title{
IMPACTAR TOOL: VALUING AIR QUALITY HEALTH IMPACTS OF URBAN BUS FLEET CHANGES IN BRAZIL
}

LUANA PRISCILA BETTI, MARINA CAREGNATO GARCIA, EDUARDO SIQUEIRA, AND HENRIQUE EVERS

\section{SUMMARY}

Air pollution is recognized as one of the greatest challenges of our time. Besides being an important contributor to climate change, several epidemiological studies indicate the association between air pollution and mortality (fatal diseases) and morbidity (nonfatal diseases). These impacts have implicit (unobservable) costs, such as hospitalization expenditures and productivity losses. The assessment and valuation of air pollution impacts is essential to make observable the implicit costs (or savings) of certain choices of economic agents (population, companies, and governments) that can increase or reduce air pollution levels. In Brazil, the transport sector accounts for the largest share of outdoor air pollution emissions, impacting the number of hospitalizations, deaths, and public and private expenditures, among other impacts.

Within the Brazilian transport sector, public urban bus fleets, dominated by diesel-powered technologies, contribute significantly to high levels of air pollution, especially particulate matter (PM). Transitioning urban bus fleets from less efficient in terms of pollutant emissions to cleaner technologies, however, can present higher investment costs because the up-front purchase price of more developed technologies is often higher compared to less efficient ones. This can discourage the improvement of a city's bus fleet. In order to promote a more accurate benefit-cost analysis of fleet renewal projects, it is crucial to measure the direct and indirect costs of premature mortalities, morbidities, workforce loss, and the associated monetary loss due to fatal and nonfatal diseases associated with variations on air pollution levels.

\section{CONTENTS}

Summary.

1. Introduction. 2

2. Methodology .3

3. ImpactAr Tool Structure... 14

4. Data Sources............................................................ 17

5. Limitations and Uncertainties ..............................................18

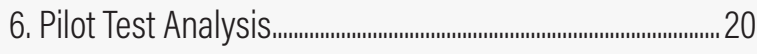

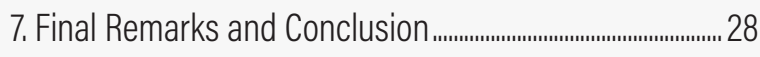

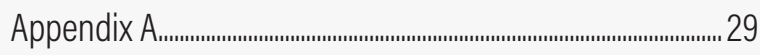

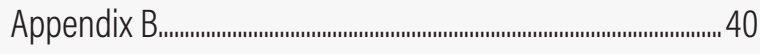

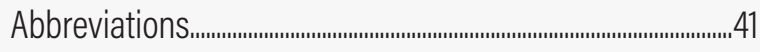

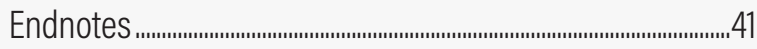

References.............................................................................. 43

WRI Technical Notes document the research or analytical methodology underpinning research publications, interactive applications, and other tools.

\footnotetext{
Suggested Citation: Betti, L. B., M. C. Garcia, E. Siqueira, and H. Evers. 2020. "ImpactAr Tool: Valuing Air Quality Health Impacts of Urban Bus Fleet Changes in Brazil." Technical Note. Porto Alegre, Brazil: WRI Brasil. Available online at: https://doi.org/10.46830/writn.21.00044
} 
This technical note presents the Valuation Tool for Health Impacts of Air Pollution (ImpactAr), a tool that aims to assess the impacts of urban air pollution on health and economy. It evaluates these health impacts and the associated monetary costs of changes in emissions levels linked to modifications in urban bus fleets in four Brazilian cities: São Paulo, Rio de Janeiro, Belo Horizonte, and Niterói. Focused on public managers-but also available for politicians, private sector operators, academics and researchers-it works as a support tool for the decision-making process, demonstrating the potential costs and returns of air pollution externality connected with investments in different transport technologies. This tool is the first step in measuring the implicit costs and benefits of changes in urban transport fleets in terms of different effects on $\mathrm{PM}_{10}$ and $\mathrm{PM}_{2.5}$ emissions and concentration levels and their impacts on fatal and nonfatal diseases. The ImpactAr tool was developed with the financial support of the Children's Investment Fund Foundation (CIFF).

\section{INTRODUCTION}

Atmospheric air pollution is the contamination of the external or internal environment by any chemical, physical, or biological agent that modifies the natural characteristics of the atmosphere (air quality). Outdoor air pollution originates from natural and anthropogenic sources. ${ }^{1}$ The most prominent polluting anthropogenic sources include fuel combustion for transport, power generation, heating, and industry (WHO 2018).

Among the main pollutants, particulate matter (PM) is commonly used as an indicator for air pollution because it affects more people than any other pollutant (WHO 2018). PM is a mixture of solid and liquid particles of organic and inorganic substances suspended in the air, including sulfate, nitrates, ammonia, sodium chloride, black carbon, mineral dust, and water. PM vary in size, composition, and origin. Whereas particles with a diameter of 10 micrometers or less $\left(\leq \mathrm{PM}_{10}\right)$ can penetrate and lodge deep inside the lungs, the even more health-damaging particles are those with a diameter of 2.5 micrometers or less $\left(\leq \mathrm{PM}_{2.5}\right)$ (WHO 2018). According to epidemiologists, air pollution represents a risk factor; this means it is not the direct cause of individual deaths (Roy and Braathen 2017), diseases, or injuries, but it significantly increases the likelihood of an individual dying or developing disease (WHO 2016).
In most of Brazil's urban areas, which compose about 84 percent of the national population (IBGE 2010), vehicles are the main source of pollutants emitted into the atmosphere (Miranda et al. 2012). Within the country's transport sector, the major contributor to PM emissions are heavy vehicles moved by diesel-mainly trucks and buses (MMA 2014). ${ }^{2}$

According to national studies, ${ }^{3}$ in terms of health impacts, outdoor air pollution in the main metropolitan regions and state capitals of the country is linked to about 20,500 annual deaths caused by cardiovascular and respiratory diseases (Miraglia and Gouveia 2014) and is responsible for 5.2 percent of hospital admissions for respiratory causes among children and 8.3 percent among elderly, totaling 4,581 respiratory admissions per year (Marcilio and Gouveia 2007). Other studies strongly suggest an association between the country's air pollution and fatal and nonfatal cases of cancer, restrictions on fetal development, and changes in the human male-to-female ratio, among others (Hettfleisch et al. 2017; Miraglia et al. 2013; Yanagi, Assunção, and Barrozo 2012). From a financial point of view, air pollution in the country leads to about 130,000 cases of work absences and a cost of US\$6,472,686 in terms of hospitalization expenditures and absences at work every year (Rodrigues-Silva et al. 2012). All of these impacts heavily affect the population's quality of life and pressure the local public budgets.

Given this scenario, urban bus fleets in most Brazilian cities continue to be outdated and less efficient in terms of PM emissions when compared to cleaner technologies available throughout the world. Low-emissions buses account for only 0.003 percent of the national urban bus fleet (NTU 2020). This can be partially explained by the fact that fleet transitions to cleaner technologies, such as electric buses, may present high investment costs because the initial purchase price of these technologies is often higher than less efficient ones (Sclar et al. 2019). Additionally, the policies, regulations, and incentives to improve a fleet are determined at the federal government level, but the health costs of air pollution particularly impact municipal budgets, reducing the incentives to a faster fleet upgrading. 
How can managers overcome these obstacles and provide municipalities with cleaner bus technologies in terms of air pollution emissions, resulting in less fatal and nonfatal diseases, lower associated costs, and increased quality of life for all Brazilians? The first step is to include the measurement of emissions variations and their implicit health costs into investment evaluation-which are not often considered-allowing managers to perform a more accurate benefit-cost analysis of projects aimed at achieving cleaner urban bus fleets.

With this goal, WRI Brasil has developed the Valuation Tool for Health Impacts of Air Pollution (ImpactAr). The interactive spreadsheet tool using Microsoft Excel measures the health impacts and the associated monetary costs of changes in emissions levels linked to modifications in urban bus fleet technologies in the cities of São Paulo, Rio de Janeiro, Belo Horizonte, and Niterói. The measurement and analysis of the impacts of such pollutants are made for a 1-year period (shortrun analysis) and a 30-year period (long-run analysis), aiming to inform users of the short-run and the longrun cumulative effects of air pollution.

The ImpactAr tool covers the impacts of $\mathrm{PM}_{2.5}$, one of the most harmful pollutants to human health, as well as $\mathrm{PM}_{10}$. The tool also provides, among other financial and economic results, the measurement of hospitalization costs in both the public and private health care systems. These monetary outcomes, interpreted as savings or costs, are compared to municipal macroeconomic variables, such as the annual municipal gross domestic product (GDPm) and annual public health budget, providing a reference of cost magnitude for users. ${ }^{4}$

Ultimately, ImpactAr serves as a support tool for decision-makers, indicating the implicit costs and returns of public investments related to air pollution in four Brazilian cities. It provides relevant information about air pollution health impacts and their consequences for the economy, which are useful information to complement the project's benefit-cost analysis and other complementary studies.

This technical note is divided into seven sections: (i) an introduction; (ii) the methodology, with clarifications on the model embedded in the ImpactAr tool; (iii) the ImpactAr tool structure; (iv) the data sources used to build the tool; (v) the limitations and uncertainties; (vi) the pilot test analysis; and (vii) concluding remarks.

\section{METHODOLOGY}

In this section, we explain the key concepts used in this technical note and describe the framework for analyzing the ImpactAr tool, the methodological choices, and the data applied in the development of the tool. ${ }^{5}$

\subsection{Key Concepts}

Bottom-up approach: In the case of air pollution assessment, a methodology that measures air pollution emissions and atmospheric concentrations by analyzing the specific sources of emissions. It is the opposite of the top-down approach, according to which the concentration levels of pollutants are first analyzed, and the sources of the emissions are estimated later on.

\section{Concentration-response coefficients (C-Rs):}

Coefficients that indicate the magnitude of response of morbidity and mortality cases related to a variation in air pollution concentration levels (Marcilio and Gouveia 2007). They are derived from epidemiological studies.

Economic costs: Economic costs measure changes in people's welfare as a consequence of air pollution. They are not related to tangible services and products (such as the cost of medical appointments), but they are based on individual perceptions and valuations, which cannot be considered financial measures. Such costs represent the assessments on the amount of value that, for individuals, is lost due to air pollution. This can be the cost of suffering caused by diseases linked to air pollution.

\section{Emissions and concentration levels of}

pollutants: Emissions are a measure of mass (tons) of pollutants emitted by one or more sources. In the ImpactAr tool, they represent the mass of $\mathrm{PM}_{2.5}$ and $\mathrm{PM}_{10}$ produced by the urban bus fleets in each city. Concentration levels express the volume of pollutants in a specific area (microgram per cubic meter, $\mu \mathrm{g} / \mathrm{m}^{3}$ ). It can differ according to temperature, humidity, wind, and other factors. Consequently, although cities can present the same emissions levels, concentration levels can vary greatly according to local conditions. 
Emissions factor: According to the U.S.

Environmental Protection Agency (EPA), "An emissions factors is a representative value that attempt to relate the quantity of a pollutant released to the atmosphere with an activity associated with the release of that pollutant" (industry, motorized vehicle, etc.) (EPA, n.d.). In the case of the ImpactAr tool, it consists of a mass of pollutant emitted by buses when consuming fuel to travel for a determined distance (measuring unit: grams of pollutant per liter of diesel, g/L).

Epidemiology: The field of study that deals with the causes and distribution of diseases and other related phenomena. Examples of epidemiological studies include issues such as the relation between smoking and lung cancer, obesity and stroke, and the causes of psychiatric disorders, among others.

Externality: This term refers to the impacts coming from the activities of one entity that change the welfare of another entity (Rosen and Gayer 2008), without the latter's consent. Externalities can be positive (e.g., vaccinations) or negative (e.g., passive smoking). For this technical note, air pollution and all of its impacts on health and economy are considered a negative externality coming from the transport sector-more specifically, coming from the public urban bus fleet.

Financial costs: The state-of-the-art literature on the monetization of air pollution impacts presents two typologies of costs: financial costs and economic costs. Financial costs are related to monetized, market-based costs. In relation to air pollution, these can be the costs of hospitalization and medical expenses caused by diseases attributable to pollutants.

Health endpoint: The type of fatal and nonfatal diseases caused by air pollution. In the case of the ImpactAr tool, health endpoints include fatal and nonfatal cardiovascular and respiratory diseases according to Chapters I and J, respectively, of the 1oth revision of the International Statistical Classification of Diseases and Related Health Problems (ICD-10).

PM fixed conversion measure (FCM): This is the estimated factor used to convert a variation of PM emissions levels into variations of PM concentration levels for each city. FCMs were obtained through two numerical experiments with the Brazilian Developments on the Regional Atmospheric Modeling System (BRAMS 5.2), ${ }^{6}$ which identified the existence of a fixed pattern in the conversion between emissions variations and concentrations variations for each city (for further discussion, please see Section 2.3, Methodology Description; and Section 5, Limitations and Uncertainties, of this technical note).

Value of statistical life (VSL): The monetization of the welfare/economic cost caused by mortality. It represents the aggregate of the individual willingness to pay (WTP) for a marginal reduction in the risk of dying from air pollution. It should be noted that this is a judgment or an evaluation of the measure of one's life; it measures the amount that individuals would be willing to pay, considering not only impacts on their income but also on their well-being, to marginally reduce their risk of dying due to air pollution.

\subsection{Framework for Analysis}

The impact of air pollution on health and economy is not direct. Before affecting a population's health and creating related costs, pollutants go through a chain of environmental, epidemiological, financial, and economic stages (Figure 1). A motorized vehicle, through its fuel combustion, brakes, tires, and road surface wear emits pollutants, among them PM. PM emissions react with atmospheric conditions (meteorological conditions, physical obstacles, etc.), resulting in a concentration level of PM in a determined region. A set of the

\section{Figure 1 | The Pollutant Chain of Impacts}

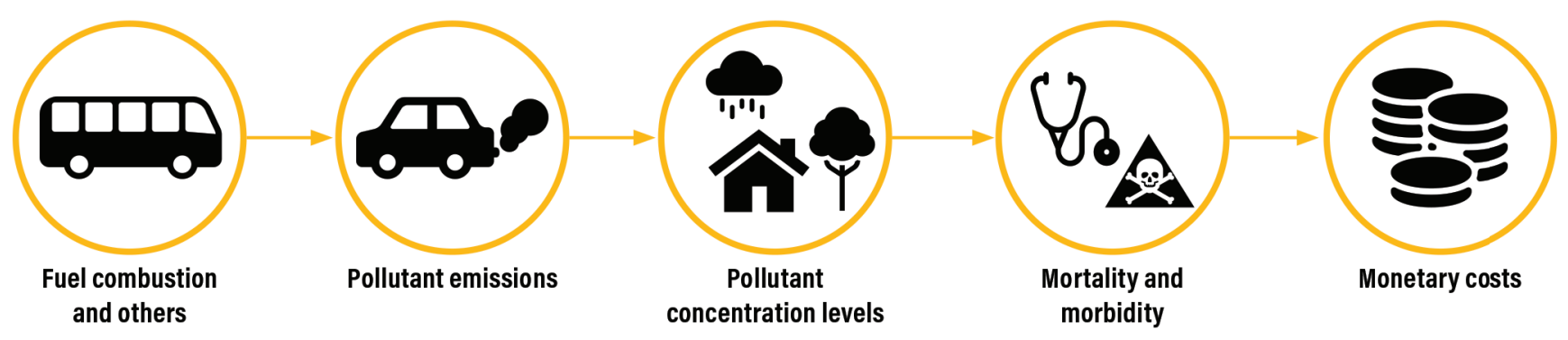

Source: WRI authors. 
population is exposed to this concentration of pollutants in the determined region and so, by increasing the likelihood of individuals suffering illnesses and deaths, cases of morbidity and mortality linked to PM are verified among the population. Finally, the premature deaths and illnesses result in monetary costs.

Measuring the health and related financial and economic impacts of air pollution requires the reproduction of this chain process. The ImpactAr tool systematizes the stages presented in Figure 1 based on the impact pathway approach (IPA) formulated by the ExternE Project.7 This approach consists of a bottom-up approach that proposes the measurement of environmental benefits and costs caused by changes in air pollution levels through a pathway from source emissions to monetary expressions of benefits and costs (ExternE, n.d.). The calculation involves two sets of components:

Data points: Data estimates that inform the results of the impacts in each stage of the IPA. For example, total annual variation in $\mathrm{PM}_{10}$ concentration levels and total annual number of avoided deaths due to cardiovascular diseases. They are represented by the boxes in Figure 2.

Linking functions: Algebraic functions that connect and convert the different stages of the IPA, allowing the assessment between distinctive types of data. They are represented by the yellow arrows in Figure 2.

In the ImpactAr tool, the set of data points and linking functions that are encompassed in the pathway are organized in a sequence of three stages, which starts with the technical solution for the urban bus fleet's renewal (for instance, the number of buses replaced for each technology):

1. Environmental Stage: This provides the annual variations in emissions and concentration levels of $\mathrm{PM}_{2.5}$ and $\mathrm{PM}_{10}$ as a result of the differences between the current fleet (scenario o) and the projected fleet (scenario 1) features.

2. Epidemiological Stage: By assessing the number of people and general epidemiological cases of cardiovascular and respiratory diseases in one city, this stage isolates the impacts of the annual concentration variations of $\mathrm{PM}_{2.5}$ and $\mathrm{PM}_{10}$ levels on the number of hospitalizations and deaths caused by cardiovascular and respiratory diseases.

\section{Financial and Economic Stage: This} stage monetizes nonfatal and fatal respiratory and cardiovascular diseases isolated in the epidemiological stage through the cost of illness (COI) methodology, which measures the financial costs of nonfatal cases, and through the VSL, which measures the economic costs of fatal cases.

Figure 2 illustrates the steps of the methodology embedded in the tool. We can list five data pointsrepresented by the boxes in Figure 2-and four linking functions applied to each data point to obtain new outcome units-represented by the yellow arrows.

Figure 2 | Methodology Steps Used in the ImpactAr Tool

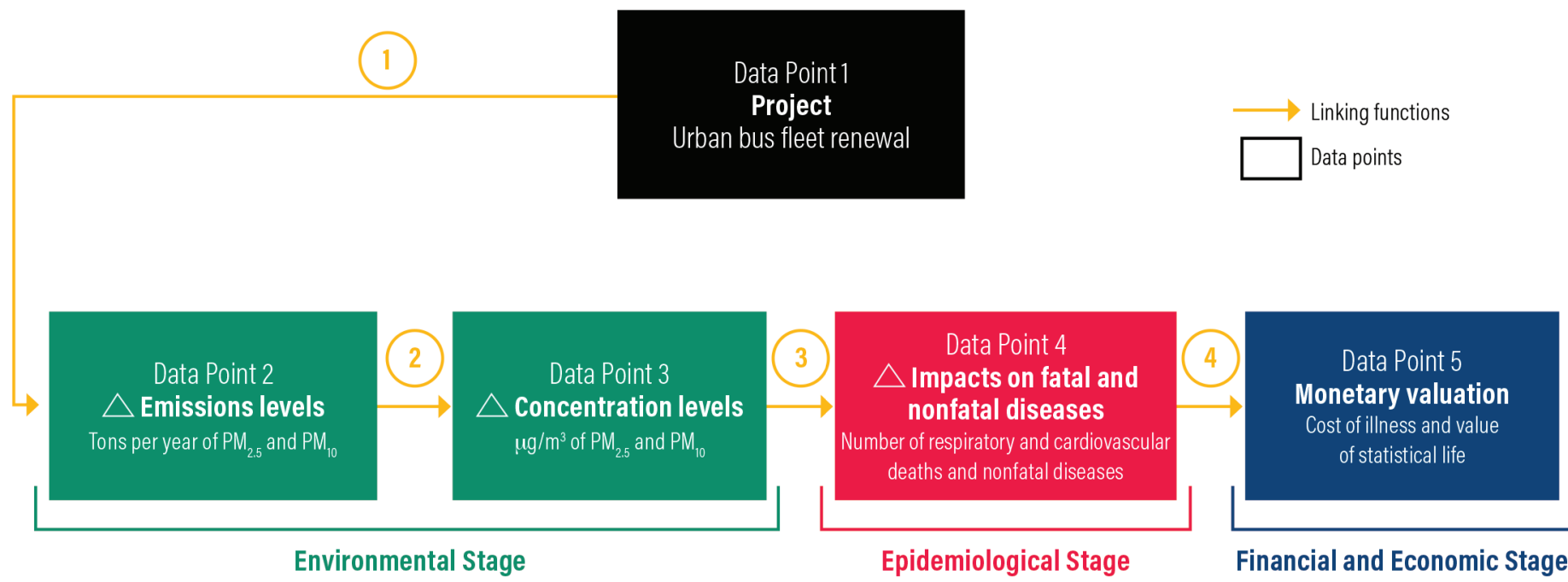




\subsection{Methodology Description}

The methodologies and data applied to build the ImpactAr tool were based on the most recent Brazilian empirical literature on the measurement of air pollution impacts on health and economy in the country. Before the development of the tool, a threestage literature review was carried out by the World Resources Institute (WRI) staff, starting from research on the main academic search platforms, followed by research of publications from leading researchers and institutions, and closing with a workshop with the main Brazilian specialists and institutions for validation of the literature review. This process resulted in 67 studies from which the impacts to be analyzed and methodologies applied were chosen. ${ }^{8}$

The ImpactAr tool comprises environmental, epidemiological, and financial methodologies and data presented in the Brazilian empirical literature, arranged according to the IPA chain process. Among others, it includes the analysis of deaths and illnesses caused by cardiovascular and respiratory diseases in the Epidemiological Stage, and it uses the COI and VSL methodologies in the Financial and Economic Stage.

The ImpactAr tool focuses on the pollutants $\mathrm{PM}_{10}$ and $\mathrm{PM}_{2.5}$ for the following reasons:

- PM imposes the most serious threat to human health compared to other pollutants (WHO 2018).

- Brazilian epidemiological literature, using a consolidated measurement methodology, identifies $\mathrm{PM}$ as responsible for a high number of health and economic impacts.

- $\mathrm{PM}_{10}$ and $\mathrm{PM}_{2.5}$ present different sources of emissions from the road transport activities ${ }^{9}$ (Hooftman et al. 2016) and distinct health incidence on the development of respiratory and cardiovascular cases $^{10}$ (Abe and Miraglia 2016; Silva et al. 2017).

- The transport sector is a major contributor of outdoor air pollution and the largest emitter of PM in Brazil (MMA 2014).

This version of the tool only fits four Brazilian cities: São Paulo, Rio de Janeiro, Belo Horizonte, and Niterói. The first three cities were chosen because they are the most important cities with which WRI Brasil has plans for implementing electric buses in their fleets. Also, they represent three of the largest vehicle fleets in the country, representing 8 percent, 3 percent, and 2 percent of the national share, respectively. ${ }^{11}$ Although Niterói has a relatively less expressive fleet in relation to the other cities-about 0.3 percent of the national fleet-the city was added due to its previous partnership with WRI Brasil in the field of electric bus impact measurement.

Unfortunately, as we expect to include more cities in the tool in the future, it will not be possible to include all Brazilian municipalities due to the size of the input data and the time required to do so. In this sense, we recommend potential users and people interested in assessing air pollution impacts due to bus fleet change projects in their cities use this technical note and the tool itself as a blueprint or a guide to build their own tool. We strongly encourage people to contact the authors in such cases, so we can help with any possible doubts and questions that may not be covered by this technical note.

A more detailed look at data points, linking functions (both presented in Figure 2), and the methodology selected to measure air pollution changes and impacts is provided below.

\subsubsection{Project}

Data point 1, technical solution: A public project aiming to renew a city's current public bus fleet. Data required is entered twice: first for the baseline or current fleet (scenario o), and then for the projected fleet (scenario 1). The ImpactAr tool requires the following input data: (i) the number of buses per technology, ${ }^{12}$ (ii) the bus technology, and (iii) the average annual travel distance per bus in kilometers $(\mathrm{km})$. Optional input data include emissions factors $(\mathrm{g} / \mathrm{L}$ ) and average fuel efficiency per technology in liters or kilowatt-hours per $100 \mathrm{~km}$ (L or $\mathrm{kWh} / 100 \mathrm{~km}$ ). If the user does not possess such information, the model will provide data by default. ${ }^{13}$

\subsubsection{Environmental Stage}

\section{Linking function 1 , from technical solution to variation on annual emissions levels: Both scenario} o fleet and scenario 1 fleet annual emissions levels (tons per year) are measured according to the formula

$$
\text { Annual PM emissions }=\mathrm{N} \times d \times C C \times e_{x}(1)
$$

where $N$ is the number of buses per technology, $\mathrm{d}$ is the average annual traveled distance per bus $(\mathrm{km}), C C$ is the annual fuel efficiency per technology (L or $\mathrm{kWh} / 100 \mathrm{~km}$ ) and $e_{x}$ is the emissions factor of PM per technology $(\mathrm{g} / \mathrm{L})$.

This formula is applied to each technology reported. It only provides annual PM emissions, without distinctions between the PM diameters, due to the methodology used to measure the PM FCMs (for further 
information, please see Linking function 2 below). In this sense, a ratio, obtained from the Handbook Emission Factors for Road Transport, model version 3.3 , is adopted to assess PM emissions of less than $10 \mu \mathrm{g}$ $\left(\mathrm{PM}_{10}\right)$ and $\mathrm{PM}$ emissions smaller than $2.5 \mu \mathrm{g}\left(\mathrm{PM}_{2.5}\right){ }^{14}$ The ratio applied is $\mathrm{PM}_{2.5} / \mathrm{PM}_{10}=0.7$. This ratio was equally applied for all four cities as, during numerical experiments to determine concentration levels, we used a regional round covering the four cities. ${ }^{15}$

It is worth noting that $\mathrm{PM}_{2.5}$ and $\mathrm{PM}_{10}$ emissions and concentration variations, as well as impacts, cannot be summed because $\mathrm{PM}_{10}$ particulates include $\mathrm{PM}_{2.5}$ particulates. In this sense, all the results are showed separately, once for $\mathrm{PM}_{10}$ and once for $\mathrm{PM}_{2.5}$.

\section{Data point 2, variation on annual emissions}

levels: This is the difference between annual $\mathrm{PM}_{2.5}$ and $\mathrm{PM}_{10}$ emissions of the current/scenario o fleet and annual $\mathrm{PM}_{2.5}$ and $\mathrm{PM}_{10}$ emissions of the projected/ scenario 1 fleet. This represents the total annual emissions variations that the technical solution would bring, if implemented. These can be represented as

$$
\begin{gathered}
\Delta \mathrm{E}_{\mathrm{PM}_{2.5}}=\text { annual } \mathrm{PM}_{2.5} \text { emissions of scenario } 1 \text { - annual } \mathrm{PM}_{2.5} \\
\text { emissions of scenario } 0 \text { (2) }
\end{gathered}
$$

$$
\begin{gathered}
\Delta \mathrm{E}_{\mathrm{PM}_{10}}=\text { annual } \mathrm{PM}_{10} \text { emissions of scenario } 1-\text { annual } \mathrm{PM}_{10} \\
\text { emissions of scenario } 0 \text { (3) }
\end{gathered}
$$

where $\Delta E_{P M_{2.5}}$ represents the total annual variation on $\mathrm{PM}_{2.5}$ emissions levels due to the technical solution, and $\Delta E_{P M_{10}}$ represents the total annual variation on $\mathrm{PM}_{10}$ emissions levels due to the technical solution.

\section{Linking function 2, from annual variations on emissions levels to annual variations on} concentration levels: Concentration levels can vary greatly according to temperature, humidity, and wind, among other factors. Consequently, concentration levels vary significantly in different geographic regions. To obtain the annual variations in concentration levels for each city, the WRI team carried out numerical experiments with the BRAMS 5.2, using the Coupled Chemistry Aerosol-Tracer Transport model (CCATT), analyzing the dispersion of the pollutants from the emissions data available from public transport scenarios. This modeling system (CCATT-BRAMS) performs predictions of weather and atmospheric composition in real-time and simultaneously (meteorology integrated with dispersion/chemistry).

The CCAT-BRAMS model was applied to evaluate the variations in the annual concentration levels. The simulations were configured to evaluate the regional dispersion of pollutants $\mathrm{PM}_{2.5}$ and $\mathrm{PM}_{10}$, associated only with the activity of the bus fleet. For this, meteorological initial and boundary conditions were used from the global model combining data from the Center for Weather Forecast and Climatic Studies (Centro de Previsão do Tempo e Estudos Climáticos, CPTEC), National Institute for Space Research (Instituto Nacional de Pesquisas Espaciais, INPE), and Global Forecast System.

Two alternative simulations were used to obtain such results. The first, developed in 2018 and named Linking function 2.1, was broader and encompassed four Brazilian cities: São Paulo, Rio de Janeiro, Belo Horizonte, and Niterói. Later, in 2020, a second version was developed to obtain more robust results for two cities in which WRI Brasil has continuously deepened its work on electromobility: Belo Horizonte and São Paulo. Due to project scope limitations and constraints (including time and budget), it was possible to update the Linking function only for these two cities.

Thus, this tool uses the PM FCMs of Niterói and Rio de Janeiro, obtained by Linking function 2.1, and FCMs of Belo Horizonte and São Paulo, by Linking function 2.2 (a PM FCM for each city). The technical parameters used in the two simulations are described below.

\section{LINKING FUNCTION 2.1:}

This broader simulation was performed including in the same spatial resolution the cities of Rio de Janeiro and Niterói. For that, a control experiment (baseline) and three scenarios modified by different technology configurations were simulated for the urban bus fleets among cities.

The emissions scenarios were simulated in grid points with $25 \mathrm{~km}$ of spatial resolution and 80 meters $(\mathrm{m})$ of thickness in the first vertical layer over the urban area of the cities, using a methodology proposed by Alonso et al. (2010). The weather conditions that calibrated the model were obtained from observed data in June 2018 in the Southeast region of Brazil.

From such simulations, a linear pattern in the conversion between the emissions variations and concentrations was identified, providing a conversion factor for each city. ${ }^{16}$ The PM FCM for Rio de Janeiro is 0.00195 and for Niterói, 0.0001407. Current fleet (scenario 0) annual variations on emissions of $\mathrm{PM}_{10}$ and $\mathrm{PM}_{2.5}$ and projected fleet (scenario 1) annual variations on emissions of $\mathrm{PM}_{10}$ and $\mathrm{PM}_{2.5}$ are multiplied by this factor. Hence,

$$
\begin{gathered}
\Delta \mathrm{E}_{\mathrm{PM}_{2.5}} \times \mathrm{FCM}=\Delta \mathrm{C}_{\mathrm{PM}_{2.5}}(4) \\
\Delta \mathrm{E}_{\mathrm{PM}_{10}} \times \mathrm{FCM}=\Delta \mathrm{C}_{\mathrm{PM}_{10}}(5)
\end{gathered}
$$


where $\Delta E_{P M_{2.5}}$ represents the total annual variation on $\mathrm{PM}_{2.5}$ emissions levels due to the technical solution, $\Delta E_{P M_{10}}$ represents the total annual variation on $\mathrm{PM}_{10}$ emissions levels due to the technical solution, FCM is the PM FCM for each city, $\Delta C_{P_{2.5}}$ represents the total annual variation on $\mathrm{PM}_{2.5}$ concentration levels due to the technical solution, and $\Delta C_{P M_{1 O}}$ represents the total annual variation on $\mathrm{PM}_{10}$ concentration levels due to the technical solution.

\section{LINKING FUNCTION 2.2:}

This approach was developed to obtain more accurate results and reduce the aggregate errors of the environmental stage inherent to Linking function 2.1. The same basis was maintained (Alonso et al. 2010) incorporating a few adjustments to the model's technical parameters, described below.

This more refined simulation was performed considering three urban transport emissions scenarios for the cities of São Paulo and Belo Horizonte. For weather conditions, the model simulated conditions of August 2019 with observed data from the city level and no longer from the regional level. The month of August is an ideal weather period, as the meteorological conditions present an adequate behavior for the purpose of this simulation, with average annual temperatures and humidity levels.

Regarding the technical parameters of the simulation, three grids of the spatial resolution were considered: 25, 5 , and 2 kilometers $(\mathrm{km})$. The same 80 meters $(\mathrm{m})$ of thickness was maintained in the first vertical layer.
The spatial distribution of emissions was performed using information data in a General Transit Feed Specification (GTFS) format, available by the transport agencies of São Paulo and Belo Horizonte. GTFS is a data specification that divides information into a static component that contains schedule, fare, and geographic transit information; and a real-time component that contains arrival predictions, vehicle positions, and service advisories (Fortin et al. 2016). GTFS was used to identify in which regions of the city there are more bus stops, and hence, are more impacted by PM emissions due to public transport-assuming the number of bus stops has a direct linear relationship with bus arrival and departure frequencies. The data were compiled using the Geographic Information System (GIS) software ArcGIS. After that, the data format was converted and exported at a resolution of $1 \mathrm{~km}$. With that, it was possible to extract relative weights of bus stops in each pixel and the spatial coordinates in text format and distribute the PM emissions. Despite being a more realistic distribution, not all cities in the Global South already have these GTFS data in accessible formats.

As in Linking function 2.1, it maintained the same linear patterns verified (Equations 4 and 5), but new conversion factors were obtained. The PM FCM is 0,0011 for São Paulo and 0,0015 for Belo Horizonte.

\section{COMPARISON BETWEEN SIMULATIONS}

The simulations performed using the CCAT- BRAMS model show some methodological differences. Table 1 compares the main differences between Linking functions 2.1 and 2.2.

Table 1 | Technical parameters of the simulations

\begin{tabular}{l|ll}
\hline PARAMETERS & LINKING FUNCTION 2.1 & LINKING FUNCTION $\mathbf{2 . 2}$ \\
\hline Period & June 2018 & August 2019 \\
Spatial resolution & $\begin{array}{l}\text { Regional-level: } 25 \mathrm{~km} \text { covering the } \\
\text { entire southeastern region of Brazil }\end{array}$ & $\begin{array}{l}\text { City-level: Different grids with } 2 \mathrm{~km} \\
\text { of spatial resolution }\end{array}$ \\
Atmospheric boundary condition & T343L42 by CPTEC/INPE & Global Forecasting System \\
Validation with observed meteorological data & Not performed & $\begin{array}{l}\text { Performed for temperature } \\
\text { and wind intensity }\end{array}$ \\
Distribution of PM emissions & $\begin{array}{l}\text { Distributed homogeneously in the } \\
\text { urban area of the city }\end{array}$ & $\begin{array}{l}\text { Distributed by weights associated with } \\
\text { the number of bus stops at each pixel }\end{array}$ \\
Cities evaluated & $\begin{array}{l}\text { Rio de Janeiro, São Paulo, Belo } \\
\text { Horizonte, and Niterói }\end{array}$ & São Paulo and Belo Horizonte
\end{tabular}


The simulation that generated the PM FCMs for Linking function 2.1 includes some limitations that were later improved. The simulation was conducted considering a widely spatial resolution at the regional level of $25 \mathrm{~km}$, using a methodology proposed by Alonso et al. (2010), native in PREP-CHEM-SRC. During the performance of this first simulation, although the model had adequate statistical adjustments, no quantitative validation was performed to assess the sensitivity of the model using observed meteorological data, due to limitations such as budget and time.

For the new simulation (Linking function 2.2), the main limitations of the first simulation have been improved. A higher resolution was used: 5 and $2 \mathrm{~km}$. This new approach led to the development of a more accurate methodology for the spatial distribution of emissions given that PM concentrations are measured by their density. Regarding the simulation period, observed meteorological data from the two cities were evaluated separately. With that, it was possible to identify a period that was suitable for the simulations considering the meteorological characteristics of each of the cities, unlike Linking function 2.1, in which the period was selected to suit the climatic characteristics of the entire Southeast region of Brazil. The data predicted by the model present adequate forecasts and satisfactory statistical adjustments with the observed data.

Spatially, it is assumed that the PM concentration in Linking function 2.2 shows improvements and better reliability, since emissions were distributed in PREPCHEM, using GTFS data with greater precision. This assumption is also based on the hypothesis that regions near bus stops-and with more bus stops deployedhave a higher concentration of particulate matter from fleets of urban buses.

Regarding atmospheric boundary conditions, in Linking function 2.1, for a $25 \mathrm{~km}$ domain, a downscaling was chosen with the outputs of the Global model provided by CPTEC/INPE, with approximately $60 \mathrm{~km}$ of spatial resolution. For Linking function 2.2, in which it was decided to work with city level (2 km), Global Forecast Model was chosen, with $25 \mathrm{~km}$ of spatial resolution, to provide the atmospheric boundary conditions. This ensures an acceptable nesting ratio between the boundary conditions and the domains. Table 2 shows the PM FCM obtained in the two simulations.

The variation observed in the results is mainly due to two factors: the distribution of PM emissions and the period evaluated. The distribution methodology significantly changes the results of the model and, consequently, the PM FCMs. The weather conditions (related to the period) can increase or decrease the variation. A period with drier weather conditions (such as the range of June up to August) results in higher concentrations, and a wetter period results in lower concentrations due to the dispersion of pollutants.

Data point 2, annual variation on concentration levels: This is the difference between annual concentrations of $\mathrm{PM}_{2.5}$ and $\mathrm{PM}_{10}$ for the current/ baseline fleet and the projected/scenario 1 fleet. This represents the total annual variation in concentration levels that the technical solution would bring, if implemented (represented as $\Delta C_{P M_{2.5}}$ and $\Delta C_{P M_{1 O}}$ in Equations 4 and 5).

\subsubsection{Epidemiological Stage}

\section{Linking function 3 , from annual variations in concentration levels to annual variations in the number of fatal and nonfatal diseases: Linking} function 3 consists of the conversion of the total annual variation in concentration levels of $\mathrm{PM}_{10}$ and $\mathrm{PM}_{2.5}$ into annual variations in the number of hospitalizations (nonfatal cases) and deaths (fatal cases) attributable to air pollution. ${ }^{17}$

Given the specificities of the state-of-the-art Brazilian epidemiological studies that measure air pollution health impacts, ${ }^{18}$ exponential functions were applied to measure health impacts in the ImpactAr tool. Such types of functions are widely used to measure air pollution impacts because they are able to account

Table 2 | Particulate matter fixed conversion measures obtained

\begin{tabular}{|l|c|c|c|}
\hline PARAMETERS & LINKING FUNCTION 2.1 & LINKING FUNCTION 2.2 & VARIATION \\
\hline São Paulo & 0.0014 & 0.0011 & $-23 \%$ \\
\hline Belo Horizonte & 0.0008 & 0.0015 & $+92 \%$ \\
\hline
\end{tabular}


for nonlinear relations among variations in pollutant concentrations and their health impacts, seasonality trends, and lags between the increase in pollution and the occurrence of the health event, among others (Conceição et al. 2001). The following epidemiological equation is used (André, Vormittag, and Saldiva 2017; Rothman and Greenland 1998)

$$
A E=\left[\operatorname{EXP}^{\left(\beta^{*} \Delta C P M x\right)}-1\right] \times T E(6)
$$

where $A E$ is the annual attributed events of fatal and nonfatal diseases due to the annual variation in concentration levels of $\mathrm{PM}_{10}$ and $\mathrm{PM}_{2.5}, \beta$ represents the $\mathrm{C}-\mathrm{R}, \Delta C_{P M x}$ represents the total annual variation in $\mathrm{PM}_{2.5}$ or $\mathrm{PM}_{10}$ concentration levels due to the technical solution implemented, and $T E$ is the total annual events of fatal and nonfatal diseases from all causes, covered by the public and private health systems. ${ }^{19}$ In this work, we consider respiratory and cardiovascular diseases.
To capture the relation between the mean increase (or decrease) in pollutant concentration and the corresponding mean increase (or decrease) in the number of health events, epidemiologists make use of C-Rs ( $\beta$ ). In the Brazilian literature on air pollution impact assessment, several ecological timeseries studies provide such coefficients for different populations, pollutants, health impacts, and age ranges. The C-Rs ( $\beta$ ) retrieved to build the ImpactAr tool come from the Brazilian empirical literature, specifically from seven articles, which are listed in Table 3. All the attributable events measured in the tool follow exactly the criteria of age range, health endpoint, and pollutant of each C-R, defined by the authors of the epidemiological studies.

Table 3 | Concentration-Response Coefficient (ß) Details and Sources

\begin{tabular}{|c|c|c|c|c|c|c|}
\hline B & AGE RANGE & AREA & $\begin{array}{l}\text { HEALTH } \\
\text { ENDPOINT }\end{array}$ & POLLUTANT & C-R & SOURCE \\
\hline$B_{1}$ & Children $(<5)$ & Mortality & $\begin{array}{l}\text { Respiratory } \\
\text { diseases }\end{array}$ & $\mathrm{PM}_{10}$ & 0.0011821980 & $\begin{array}{l}\text { Marcilio and } \\
\text { Gouveia } 2007\end{array}$ \\
\hline$B_{2}$ & Children $(<5)$ & Morbidity & $\begin{array}{l}\text { Respiratory } \\
\text { diseases }\end{array}$ & $\mathrm{PM}_{10}$ & 0.0010138430 & $\begin{array}{l}\text { Gouveia et. al. } \\
2017\end{array}$ \\
\hline$B_{3}$ & Elderly $(\geq 60)$ & Mortality & $\begin{array}{l}\text { Respiratory } \\
\text { diseases }\end{array}$ & $\mathrm{PM}_{10}$ & 0.0013212330 & Costa et al. 2017 \\
\hline$B_{4}$ & Elderly $(\geq 60)$ & Mortality & $\begin{array}{l}\text { Cardiovascular } \\
\text { diseases }\end{array}$ & $\mathrm{PM}_{10}$ & 0.000010000 & Costa et al. 2017 \\
\hline$B_{5}$ & Elderly ( $\geq 65)$ & Morbidity & $\begin{array}{l}\text { Respiratory } \\
\text { diseases }\end{array}$ & $\mathrm{PM}_{10}$ & 0.001960024 & $\begin{array}{l}\text { Marcilio and } \\
\text { Gouveia } 2007\end{array}$ \\
\hline$B_{6}$ & Elderly (>39) & Morbidity & $\begin{array}{l}\text { Cardiovascular } \\
\text { diseases }\end{array}$ & $\mathrm{PM}_{10}$ & 0.000999983 & Gouveia et al. 2017 \\
\hline$B_{7}$ & All ages & Mortality & $\begin{array}{l}\text { Respiratory } \\
\text { diseases }\end{array}$ & $\mathrm{PM}_{2.5}$ & 0.0010148330 & $\begin{array}{l}\text { Fajersztajn et al. } \\
2017\end{array}$ \\
\hline$B_{8}$ & Children $(<12)$ & Morbidity & $\begin{array}{l}\text { Respiratory } \\
\text { diseases }\end{array}$ & $\mathrm{PM}_{2.5}$ & 0.008925820 & $\begin{array}{l}\text { Nascimento et al. } \\
2016\end{array}$ \\
\hline$B_{9}$ & Elderly ( $\geq 45)$ & Mortality & $\begin{array}{l}\text { Cardiovascular } \\
\text { diseases }\end{array}$ & $\mathrm{PM}_{2.5}$ & 0.0010544210 & $\begin{array}{l}\text { Rodrigues et al. } \\
2017\end{array}$ \\
\hline$B_{10}$ & Elderly (>64) & Morbidity & $\begin{array}{l}\text { Respiratory } \\
\text { diseases }\end{array}$ & $\mathrm{PM}_{2.5}$ & 0.0042101180 & Ignotti et al. 2010 \\
\hline$B_{11}$ & Elderly ( $\geq 45$ ) & Morbidity & $\begin{array}{l}\text { Cardiovascular } \\
\text { diseases }\end{array}$ & $\mathrm{PM}_{2.5}$ & 0.002254400 & $\begin{array}{l}\text { Rodrigues et al. } \\
2017\end{array}$ \\
\hline
\end{tabular}


At first, it may seem counterintuitive to assume that impacts on specific age ranges are representative of the population's health impacts as a whole. Nevertheless, due to the nonlinear nature of the relation between pollutant variations and health impact variations, children and the elderly are the segments of the population that experience much higher-than-average personal health impacts caused by air pollution. By assessing the impacts of this risk group, we are able to provide a more sensitive basis for the detection of any increase in disease (National Research Council 1988).

\section{Data point 4, annual variations on the number of fatal and nonfatal diseases: This represents} the health impacts linked to the technical solution chosen. It provides the changes in the number of hospitalizations and deaths due to respiratory and cardiovascular diseases as a consequence of the annual variation in $\mathrm{PM}_{2.5}$ and $\mathrm{PM}_{10}$ concentrations. Annual variations in the number of fatal and nonfatal cases are provided for 1 year and 30 years.

\section{Box 1 | The Calculus of Total Events (TE): The Number of Fatal and Nonfatal Diseases from All Causes}

Exposure refers to a "pollutant concentration at a particular place and time, and the presence of a person at that place and time." a It can vary according to (i) the magnitude of the concentration level, (ii) the duration of the exposure to the pollutant, and (iii) the frequency of exposure to the pollutant. ${ }^{b}$ This entails that, within a city, exposure levels, and therefore health impacts, differ greatly according to the person's mobility trends and living area. The ImpactAr tool does not measure different levels of exposure among the population in each city due to the lack of data regarding georeferenced information on PM concentration levels in different areas of the analyzed cities and specific features of the population's mobility in those areas. Instead, our model uses the total number of fatal and nonfatal cardiovascular and respiratory diseases from all causes in each city as a baseline. To obtain such numbers for a 30 -year analysis, a projection of population, morbidity rate, and mortality rate, considering the concentration-response coefficient criteria of age range and health endpoints, was measured.

The population projections were calculated on the basis of population forecast estimates from local government studies combined with polynomial interpolation in the years for which data were missing. Mortality and morbidity rates were projected from data retrieved from the Department of Information Technology of the National Public Health System (Departamento de Informática do Sistema Único de Saúde, DATASUS). For fatal disease forecasts, we used cross-sectional DATASUS data on the number of deaths, and for nonfatal diseases we used crosssectional DATASUS data on hospitalizations-both from 2000 to 2017. To maintain the reasonableness of the behavior of fatal and nonfatal cases until 2050 (30-year analysis), we set the 2050 value as the best result in these health indicators (the minimum value reached) in the data provided by DATASUS (2000-17). Our main assumption is that, over the years, the overall health of the population will improve, reaching the best result already reached-and therefore the lowest number-of fatal and nonfatal cardiovascular and respiratory diseases.

The projections were made through direct linear extrapolation, according to the following model, ${ }^{\mathrm{c}}$

$$
\ln \left(m_{x, t}\right)=a_{x}+b_{x} t+E_{x, t}
$$

where $m_{x, t}$ is the mortality/morbidity rate of interest, for age $x$, in year $t ; a_{x}$ means the mortality/morbidity constant for age; $b_{x}$ denotes the age-specific multiplied by time $t_{;} E_{x, t}$ is the residual error. It is fundamentally a log-linear model, with the mortality/ morbidity rate as the dependent variable and the year, as well as a constant, as an explanatory variable.

In possession of the population forecasts, we applied the projected mortality and morbidity rates of respiratory and cardiovascular diseases from all causes to obtain the absolute number of occurrences. The number of deaths provided by DATASUS covered both occurrences in the public health system as well as in the private health system. For hospitalizations, however, data provided only covered hospitalizations in the public health system. Therefore, in order to find hospitalizations in the private health system, we applied the method of André et al. (2012) as follows,

$$
\mathrm{N}_{\mathrm{ps}}=\mathrm{N}_{\text {public }}\left(\frac{1}{(1-\mathrm{PI})}\right)-1
$$

where $N_{p s}$ is the number of hospital admissions in the private system, $N_{\text {public }}$ is the number of hospital admissions in the public system, and $P I$ is the proportion of the population with access to private health insurance.

Note: There are several methods for projecting mortality/morbidity. Direct linear extrapolation is not meant to be accurate but rather to point to trends. This method is traditionally used in this kind of study (Stoeldraijer et al. 2013). Methods that include additional information or an extra dimension to the data (e.g., cohort) "will automatically lead to a more subjective model.... Models which capture age, period, and cohort effects in mortality will provide a better model fit than age-period models, given that a cohort effect exists in the mortality data... However, there is no guarantee that models with a better fit will produce better forecasts" (Stoeldraijer et al. 2013, 344-45).

Sources: a. National Research Council 1988, 208; b. National Research Council 1988; c. Booth and Tickle 2008; Stoeldraijer et al. 2013. 


\subsubsection{Financial and Economic Stage}

Linking function 4 , from annual variations on the number of fatal and nonfatal diseases to monetary valuation: The monetization of the changes in the numbers of fatal and nonfatal diseases applied in the tool was divided between morbidity costs and mortality costs. For the former, we have opted to monetize the cost of nonfatal diseases attributable to air pollution through the financial approach, as the Brazilian literature used the wellgrounded COI methodology. ${ }^{20}$ For the latter, we chose to use a measure of economic cost that is not often verified in the Brazilian literature-namely, the VSL. Yet however controversial the VSL may be, it aims to measure nonmarket costs related to suffering and loss of well-being, broadening the spectrum of costs covered by the ImpactAr tool.

a. Morbidity costs: According to the COI methodology, the financial impacts of hospitalizations consist of the sum of two types of costs:

Direct cost of disease: This represents the total costs of hospitalizations. It is measured using the average cost of hospitalizations in 2018 provided by the Department of Information Technology of the National Public Health System (Departamento de Informática do Sistema Único de Saúde, DATASUS) for each age range and health endpoint of the C-Rs and the annual attributed events of nonfatal diseases due to the variation on concentration levels. As DATASUS only provides the average cost of hospitalizations in the public health system, we assumed that the average cost of hospitalizations in the private system is three times higher in relation to public ones, as proposed by André et al. (2012). The total direct cost according to each age range and health endpoint is given by

$$
\mathrm{TDC}=\mathrm{AC} \times \mathrm{AD}(7)
$$

where $T D C$ is the total annual direct cost of nonfatal diseases, $A C$ is the average cost of each hospitalization for each age and health endpoint, and $A D$ is the annual attributed nonfatal diseases due to the variation on concentration levels.
Indirect cost of disease: This represents the cost of work absences due to hospitalizations. It is measured for each age range and health endpoint of the C-Rs, and it uses the average stay of hospital admissions in 2018 provided by DATASUS (we assumed that the average stay of hospitalizations in the private system is the same as in the public system); individual daily per capita earnings of all sources in 2015 (2018R $\$$ ) per city, which were measured by dividing by 30 the average monthly earning of all sources in 2015 provided by Brazilian Institute of Statistics and Geography (Instituto Brasileiro de Geografia e Estatística, IBGE); and the number of the annual attributable events of nonfatal diseases due to the annual variation on concentration levels. This can be summarized by the formula

$$
\mathrm{TIC}=\mathrm{AS} \times \mathrm{DI} \times \mathrm{AD}(8)
$$

where TIC represents the total annual indirect cost of disease, $A S$ is the average stay of hospital admissions for each age range and health endpoint of C-Rs, $D I$ is the individual daily income per capita of all sources per city, and $A D$ is the annual attributed nonfatal diseases due to the variation on concentration levels.

Besides the indirect cost of morbidity, the ImpactAr tool also provides the number of workdays lost due to hospitalizations. Although we analyze the impacts in non-working-age ranges, we assume that someone active, both in the formal and informal job market, will be absent from work to take care of the ill, as proposed by Ortiz-Durán and Rojas-Roa (2013).

Finally, the total financial cost of morbidity impacts, or the COI, calculated by the tool is given by the equation

$$
\mathrm{COI}=\mathrm{TDC}+\mathrm{TIC}(9)
$$

where $T D C$ is the total annual direct cost of nonfatal diseases and TIC represents the total annual indirect cost of disease. 
b. Mortality costs: Mortality costs were measured by multiplying the number of deaths by the VSL for Brazil in 2018, as presented in Equation 10. They are measured for each age range and health endpoint of the C-Rs,

$$
M C=N D \times V S L(10)
$$

where $\mathrm{MC}$ is the total cost of mortality, ND is the annual number of deaths, and VSL is the value of statistical life for Brazil.

Brazil does not present an extensive literature ${ }^{21}$ that measures the VSL for air pollution through revealed preference or state preference methods. ${ }^{22}$ We have opted to adopt the unit value transfer method to obtain the VSL value, according to which we transfer data from previous studies of stated preference or revealed preference from one context to another, with adjustment for specific variables. The methodology applied has been widely used by the Organization for Economic Co-operation and Development (OECD) (OECD 2012, 2014; Roy 2016; Roy and Braathen 2017; WHO/Europe and OECD 2015). Specifically, for the ImpactAr tool, we adopted the methodology proposed by an OECD study (Roy and Braathen 2017) that targeted the countries of Brazil, Russia, Indonesia, India, China, and South Africa (BRIICS). The value transferred was the 2005 VSL for OECD countries, US\$3 million (2005\$) (OECD 2012). According to the formula we applied, we adjusted the value for the difference in per capita income, income per capita growth from 2005 and 2018, and inflation from 2005 and 2018 (Roy and Braathen 2017):

$\mathrm{VSL}_{\text {BRASIL,2018 }}=V S L_{0 E C D, 2005} \times\left(\frac{\mathrm{Y}_{\text {BRASLL,2005 }}}{\mathrm{Y}_{\text {OECD,2005 }}}\right)^{\mathrm{b}} \times(1+\% \Delta \mathrm{P}+\% \Delta \mathrm{Y})^{\mathrm{b}}(11)$

where $V S L_{B R A S I L, 2018}$ is the value of statistical life for Brazil in 2018; $V S L_{O E C D, 2005}$ is the base value for OECD countries in 2005; $Y_{B R A S L, 2005}$ is the GDP per capita in terms of purchasing power parity at 2018 prices for Brazil in 2005; $Y_{O E C D, 2005}$ is the per capita GDP in terms of purchasing power parity at 2018 prices for OECD countries in 2005; b is the income elasticity of VSL (considered to be 1 , as proposed by Roy and Braathen $[2017,17]) ; \% \Delta P$ represents the price inflation in Brazil between 2005 and 2018, as estimated by the consumer price rate; and $\% \Delta Y$ is the real income growth between 2005 and 2018 for the country. All the economic indicators were retrieved from the OECD online database.
Data point 5, monetary valuation: This represents the monetization of the variations in health impacts found in the Epidemiological Stage. For costs related to changes in morbidity impacts-namely, variations in the number of hospitalizations-we used the COI methodology, which can be interpreted as the financial savings/ costs of health treatment and income avoided/ generated due to the total decrease/increase on $\mathrm{PM}_{2.5}$ and $\mathrm{PM}_{10}$ annual concentration levels. For costs associated with mortality, in their turn, the VSL was used. In simple terms, the VSL is an estimate of how much people are willing to pay to reduce their risk of death, taking into account issues such as suffering and discomfort. Therefore, this cost represents more than the financial impacts of mortality, aiming to evaluate the impact on welfare losses due to a fatality.

Monetary values are measured in Brazilian reals $(\mathrm{R} \$)$ at 2018 prices and a discount rate of 6.75 percent per year was used for the 30-year analysis (February 2018, Brazilian basic interest rate, called the Special System for Settlement and Custody Sistema Especial de Liquidação e de Custódia (SELIC) rate). The concept behind the use of the discount rate for projections is intended to deal with future inflation, making future costs comparable to current 2018 Brazilian prices (2018R\$). 


\section{IMPACTAR TOOL STRUCTURE}

The presented methodology was used to build an interactive spreadsheet tool using Microsoft Excel 2013. The tool presents a cover, with a brief model description and menu, and a user guide, with details on each spreadsheet's functions (Figures 3 and 4).

Figure 3 | Interface of the ImpactAr Tool Cover

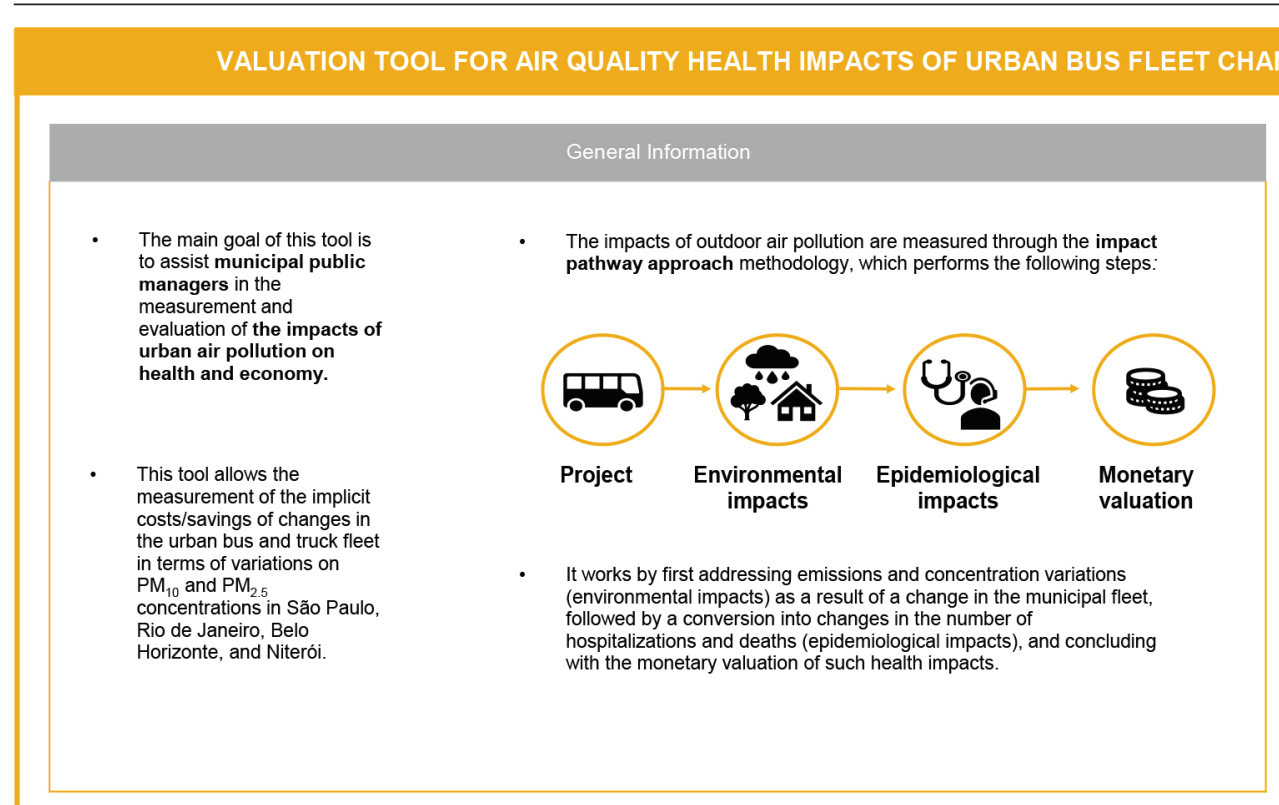

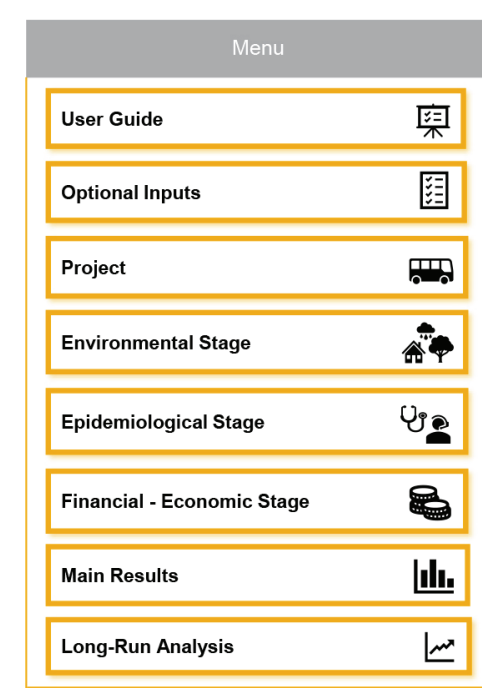

WRI BRASIL

Source: ImpactAr tool. 
Figure 4 | Interface of the ImpactAr Tool User Guide

This tool contains the following spreadsheets:

- In this spreadsheet, the user can either choose to change the following data or to use the model values by default: (i) emissions factor per technology $(\mathrm{g} / \mathrm{L})$ and (ii) average fuel consumption per technology $(\mathrm{L}$ or $\mathrm{kWh} / 100 \mathrm{~km})$.

\section{PROJECT}

- It contains the input information regarding the public project aimed at the renewal of the current urban bus fleet

- Data required includes (i) the city where the project will be implemented, (ii) number of buses, (iii) type of technology (e.g., Euro V), and (iv) the annual traveled distance $(\mathrm{km})$.

- All information above is filled in twice: once for the current fleet and once for the projected fleet.

- If you do not possess the information required for the current and/or projected fleet, you can add the annual particulate matter (PM) emissions or concentration changes you wish.

\section{EnVIRONMEnTal. STAGE}

- It provides $\mathrm{PM}_{2.5}$ and $\mathrm{PM}_{10}$ emissions and concentration levels of the current fleet and of the projected fleet.

- Emissions data is given in tons/year and concentration data is given in $\mu \mathrm{g} / \mathrm{m}^{3}$.

\section{UP 3.epidemiological stage}

- Variations in the numbers of epidemiological cases are provided as a consequence of the changes in the concentration levels of $\mathrm{PM}_{2.5}$ and $\mathrm{PM}_{10}$.

- Epidemiological data consists of cases of fatal diseases and cases of nonfatal diseases

- The analysis of epidemiological impacts covers a period of 30 years

- All epidemiological data provided refers to the impact in 1 year (short-run analysis) and the cumulative impact of 30 years (long-run analysis) due to the change in the urban bus fleet.

\section{FINANCIAL AND ECONOMIC STAGE}

- Morbidity costs (nonfatal diseases) and mortality costs (fatal diseases) are provided as a consequence of variations in the number of epidemiological cases due to changes in the concentration levels of $\mathrm{PM}_{2.5}$ and $\mathrm{PM}_{10}$.

- Morbidity costs can be divided into direct costs, which represent hospitalization expenditures, and indirect costs, which represent the costs due to absences at work.

- Whereas morbidity costs represent financial costs, that is, costs incurred by the municipality or by the population, mortality costs are of economic nature, aimed at measuring the less tangible matters, such as suffering and loss of leisure.

- All financial and economic data provided refers to the impact in 1 year (short-run analysis) and the cumulative impact of 30 years (long-run analysis) due to the change in the urban bus fleet.

\section{IIIIIIIIN RESULTS}

- It provides the main results - environmental, epidemiological, and economic-financial-that the changes in the concentration levels of $\mathrm{PM}_{2.5}$ and $\mathrm{PM}_{10}$ would produce.

- It also offers a comparative analysis between economic and financial results provided by the model and economic indicators from the municipality, such as the municipal GDP, municipal annual health expenditure, and average cost of hospitalizations in the municipality. This analysis covers 1 year (short-run analysis) and 30 years (long-run analysis).

\section{6_LONG-RUN ANALYSIS}

- It provides graphs with the evolution of morbidity and mortality cases and their respective costs over the period of 30 years (long-run analysis), with data numbers provided every 5 years. 
After these two first sections, the tool presents another seven spreadsheets. The first corresponds to an optional input section, the second to a required input section, and the following five spreadsheets consist of sections for reports and results. Each one contains specific types of data; Table 4 provides a summary.

As specified, the sixth and seventh spreadsheets (Main Results and Long-Run Analysis) are not part of the stages presented in Figure 2, but they provide a summary of main results and economic comparisons.
The interfaces of all the other spreadsheets mentioned in Table 2 are presented in Appendix A.

Besides the 9 spreadsheets presented above (Cover, User Guide, Optional Inputs, Project, Environmental Stage, Epidemiological Stage, Financial and Economic Stage, Main Results, and Long-Run Analysis), the tool has 10 additional support spreadsheets that cannot be visualized or modified by the user. These sections contain all default data used as well as the calculations and databases of health, financial, and economic impacts measured by the tool.

Table 4 | ImpactAr: Tool Contents and Structure

\begin{tabular}{|c|c|c|}
\hline ORDERING & $\begin{array}{l}\text { SHEET } \\
\text { REFERENCE NAME }\end{array}$ & MAIN CONTENTS \\
\hline Sheet 1 & Optional Inputs & $\begin{array}{l}\text { This is an optional input sheet that enables users to change the PM emissions factor and average fuel } \\
\text { efficiency per technology of buses. The values available in the model by default are provided in the only } \\
\text { table of the spreadsheet, in the white cells. Note that users should only fill the optional value in the green } \\
\text { cells of the table if they have the data required. Otherwise, the user should keep the green cells with N/A } \\
\text { value, as the model will provide data by default. }\end{array}$ \\
\hline Sheet 2 & Project & $\begin{array}{l}\text { The user enters the data for the fleet's renewal project, including data on the city's current bus fleet or } \\
\text { any baseline fleet (scenario 0) and data on the city's projected bus fleet (scenario 1). If the user does not } \\
\text { possess fleet data to enter, she/he can input any value of annual emissions or concentration levels of } \\
\mathrm{PM}_{2.5} \text { or } \mathrm{PM}_{10} \text { in the "Environmental Input Data" subsection and the tool will measure the epidemiological, } \\
\text { financial, and economic impacts in the following spreadsheets. In this case, the values entered will } \\
\text { represent annual variations on air pollution levels linked to the transport sector. This means that the tool } \\
\text { will assume that air pollution levels for scenario } 1 \text { represent the values inputted by the user, and the air } \\
\text { pollution levels for scenario } 0 \text { will be equal to zero. }\end{array}$ \\
\hline Sheet 3 & $\begin{array}{l}\text { Environmental } \\
\text { Stage }\end{array}$ & $\begin{array}{l}\text { It provides the annual emissions and concentration levels of } \mathrm{PM}_{2.5} \text { and } \mathrm{PM}_{10} \text { both for the current and the } \\
\text { projected fleet. If the user provides data directly through the in the Environmental Input Data subsection } \\
\text { of the "Project Stage," he or she can go directly to the next spreadsheet, "Epidemiological Stage." }\end{array}$ \\
\hline Sheet 4 & $\begin{array}{l}\text { Epidemiological } \\
\text { Stage }\end{array}$ & $\begin{array}{l}\text { It provides the numbers of epidemiological cases (hospitalizations and deaths) attributable to the difference } \\
\text { between the annual concentration levels of } \mathrm{PM}_{2.5} \text { and } \mathrm{PM}_{10} \text { linked to the current fleet (scenario } 0 \text { ) and the } \\
\text { annual concentration levels of } \mathrm{PM}_{2.5} \text { and } \mathrm{PM}_{10} \text { linked to the projected fleet (scenario 1). It also offers the } \\
\text { number of work absences due to hospitalizations. Values are provided for } 1 \text { year (short-run analysis) and } 30 \\
\text { years (long-run analysis). If the user provides data directly through the Environmental Input Data subsection } \\
\text { of the Project Stage, the number of fatal and nonfatal diseases provided by ImpactAr represents an } \\
\text { estimation of health endpoints due to the annual variation on emissions and concentration levels inputted. }\end{array}$ \\
\hline Sheet 5 & $\begin{array}{l}\text { Financial and } \\
\text { Economic Stage }\end{array}$ & $\begin{array}{l}\text { Morbidity costs (nonfatal diseases) and mortality costs (fatal diseases) are provided as a consequence of } \\
\text { the changes in the annual concentration levels of } \mathrm{PM}_{2.5} \text { and } \mathrm{PM}_{10} \text { caused by the fleet's renewal. Values are } \\
\text { provided for } 1 \text { year (short-run analysis) and } 30 \text { years (long-run analysis). If the user provides data directly } \\
\text { through the Environmental Input Data subsection of the Project Stage, the financial and economic costs } \\
\text { of fatal and nonfatal diseases represent an estimation of the costs associated with the epidemiological } \\
\text { cases due to the annual variation in emissions and concentration levels inputted. }\end{array}$ \\
\hline
\end{tabular}

It provides the main results-environmental, epidemiological, and financial-economic-that the changes in $\mathrm{PM}_{10}$ and $\mathrm{PM}_{2.5}$ annual concentration levels originated by the fleet's renewal or by the direct air quality inputs of the user (in the Environmental Input Data subsection of the Project Stage) would produce. It also

Sheet $6 \quad$ Main Results offers a comparative analysis between economic and financial results and economic indicators of the municipality, such as the municipal GDP, municipal annual health expenditure, municipal annual hospital expenditure, and average cost of hospitalizations in the municipality. Values are provided for 1 year (shortrun analysis) and 30 years (long-run analysis).

Sheet $7 \quad$ Long-Run It provides graphics with the evolution of morbidity and mortality cases and their respective costs over Analysis the period of 30 years, with data numbers provided every 5 years. 


\section{DATA SOURCES}

All external data sources used to build the ImpactAr tool are summarized in Table 5, with specifications on their locations.

\section{Table 5 | Data Source Specifications}

DATA

Emissions factor per

technology ( $\mathrm{g} / \mathrm{L})$

Average fuel efficiency per technology (L or kWh/100 km)
SOURCES

SPREADSHEET

DEFAULT_DATA_ENVIRONMENTAL

São Paulo Transportation (São Paulo Transporte)

Operation experience-reported to the World Resources Institute-

from a large Brazilian city. The name of the city will not be provided as

to avoid relevant information disclosure.

For average electric consumption, we added the average of the

DEFAULT_DATA_ENVIRONMENTAL operation data of nine Padron electric buses of a pilot carried out in Santiago, Chile.

Broad National Consumer Price Index (Índice Nacional de Preços ao Consumidor Amplo, IPCA)

Particulate matter fixed conversion measures (FCM) for emissions concentration

Municipal gross domestic product-2015 (2018R\$)

Annual municipal health expenditure in 2018 (RS)

\section{Average cost of hospitalizations from all causes in 2018 (RS)}

\section{Average hospital expenditure} in 2018 from all causes per city (RS)

\section{Resident population per city and age ranges (table)}

Private health insurance coverage per city in August 2018 (\%) (table)

Average stay of
hospitalizations in 2018 (table)

Value of statistical life for Brazil in 2018 (R\$)

Discount rate
Brazilian Institute of Statistics and Geography (Instituto Brasileiro de Geografia e Estatística; IBGE) ${ }^{c}$

DEFAULT_DATA_ENVIRONMENTAL Obtained through simulations in the Coupled Chemistry AerosolTracer Transport model to the Brazilian Developments on the Regional DEFAULT_DATA_ENVIRONMENTAL Atmospheric Modeling System (CCATT-BRAMS) model.

$\mathrm{BBGE}^{\mathrm{d}}$

DEFAULT_DATA_ENVIRONMENTAL

São Paulo: 2018 data from the Municipal City Hall (Prefeitura do

Município de São Paulo) ${ }^{e}$

Rio de Janeiro: 2018 data from the Municipal City Hall (Prefeitura da

Cidade do Rio de Janeiro $)^{\dagger}$

Belo Horizonte: 2018 data from Municipal City Hall (Prefeitura

DEFAULT_DATA_ENVIRONMENTAL

Municipal de Belo Horizonte) ${ }^{9}$

Niterói: 2018 data from the Municipal City Hall (Prefeitura Municipal de Niterói)

Department of Information Technology of the National Public Health System (Departamento de Informática do Sistema Único de Saúde; DATASUS)

DEFAULT_DATA_ENVIRONMENTAL DATASUS

DEFAULT_DATA_ENVIRONMENTAL

DATASUS (2011-12: IBGE population estimates submitted to the Federal Audit Court (Tribunal de Contas da União, TCU), stratified by age and sex by MS/SGEP/DATASUS) ${ }^{\mathrm{h}}$

DEFAULT_DATA_EPIDEMIOLOGICAL

National Agency of Supplementary Health (Agência Nacional de Saúde Suplementar, ANS)

DEFAULT_DATA_EPIDEMIOLOGICAL DATASUS

DEFAULT_DATA_FIN_AND_ECO

Value obtained by transferring the value of statistical life to OECD countries in 2005, as proposed by Roy and Braathen (2017)

DEFAULT_DATA_FIN_AND_ECO

Brazilian basic interest rate in February 2018 (SELIC rate) per the Brazilian Central Bank (Banco Central do Brasil) ${ }^{i}$ 
Average individual monthly income of all sources per city in 2015 (2018R\$)

\section{Average cost of PUBLIC hospitalization in 2018 (RS)}

Average cost of PRIVATE hospitalization in 2018 (RS)

\section{Population forecasts} for São Paulo

Population forecasts for Belo Horizonte

\section{Population forecasts} for Rio de Janeiro Population forecasts for Niterói
IBGE Automatic Recovery System (Sistema IBGE de Recuperação Automática, SIDRA)j

DATASUS

DEFAULT_DATA_FIN_AND_ECO

The average cost of hospitalizations in the private system was considered to be three times higher in relation to public ones, as proposed by André et. al (2012)

Foundation for the State System of Statistical Data Analysis (Fundação Sistema Estadual de Análise de Dados Estatísticos, SEADE)

DEFAULT_DATA_POPPROJ João Pinheiro Foundation (Fundação João Pinheiro) population studies

DEFAULT_DATA_POPPROJ Pereira Passos Institute (Instituto Pereira Passos)

DEFAULT_DATA_POPPROJ

Municipal Secretary of Urbanism and Mobility (Secretário Municipal de Urbanismo e Mobilidade)
DEFAULT_DATA_POPPROJ

Notes: $\mathrm{g} / \mathrm{L}=$ grams of pollutant per liter of diesel; $\mathrm{L}$ or kWh/100 km = liters or kilowatt-hours per 100 kilometers; SELIC = Sistema Especial de Liquidação e de Custódia.

Sources: a. MMA 2011; b. SPTrans 2012; c. IBGE, n.d.b; d. IBGE 2017; e. Prefeitura do Município de São Paulo 2018a; f. Prefeitura da Cidade do Rio de Janeiro 2018; g. Prefeitura Municipal de Belo Horizonte 2018; h. IBGE, n.d.a; i. BCB 2018; j. IBGE 2015; k. Fundação SEADE 2017; I. SMU 2015.

\section{LIMITATIONS AND UNCERTAINTIES}

Although the ImpactAr tool offers a robust model to measure air pollution impacts, limitations and uncertainties are inexorable, but identifying them will help users better interpret the results. We have segregated the main limitations according to the stages presented in Section 2, Methodology, additionally including an overall limitations analysis.

Environmental Stage limitations: The main issue that may raise controversy in this stage is related to the methodology applied to convert PM emissions into PM concentration levels. This conversion is based on a fixed conversion factor for each city, which may mislead the user to believe that the different variables that influence concentration levels were not considered. The PM FCMs, however, incorporate aspects inherent to the atmospheric simulation for the period and region analyzed in the BRAMS 5.2 modeling system, such as wind influence, atmospheric boundary layer behavior, soil-atmosphere interaction, and mesoscale and synoptic scale phenomena. In this study, due to scope limitations, the period considered for atmospheric modeling is one month of the year for each Linking function (June and August), which is representative in meteorological conditions.
For the first simulation (Linking function 2.1), the emissions scenarios for each city were interpolated on a gridded domain ( $25 \mathrm{~km}$ ) over an urban area of the cities, using a methodology proposed by Alonso et al. (2010), native in PREP-CHEM-SRC. The emissions preprocessing tool (Freitas et al. 2011) is a comprehensive tool for preparing emissions fields of trace gases and aerosols for use in atmospheric chemistry transport models. For the second simulation (Linking function 2.2), to mitigate the limitations of the domain and spatial distribution, $2 \mathrm{~km}$ of spatial resolution and the GTFS data were combined for each city. For both simulations, the $80 \mathrm{~m}$ of thickness in the first vertical layer was chosen due to the computational resource associated with the timetable for the delivery of the tool.

Another limitation is the use of two different simulations (Linking functions 2.1 and 2.2) to obtain the FCMs of the four cities. The different methodological paths taken do not allow direct comparisons among the four cities. 
Although FCMs carry limitations-such as meteorological boundary conditions of one month, coarse-grid resolution, and some model limitations like atmospheric parameterization-they are a useful option for ImpactAr tool users because this methodology does not require expertise in atmospheric modeling. Furthermore, the FCMs are sensitive only to bus fleet emissions scenarios, and the inclusion of additional meteorological boundary conditions like Representative Concentration Pathway (RCP) scenarios, ${ }^{23}$ for example, would bring more uncertainty to the simulations of PM concentration.

\section{Epidemiological Stage limitations: All dose-} response coefficients retrieved measure the short-term effect of PM on health (usually on the same day of the exposure, up to seven days past). The epidemiological evidence indicates that the long-term effects of air pollution also negatively affect people's health (Beelen et al. 2014; Pope 2007). The Brazilian literature, however, does not present an extensive list of such studies. In order to consider a long-term analysis, the ImpactAr tool sums the impacts of air pollution measured by short-run dose-response coefficients for the 30-year analysis. Furthermore, we have retrieved the coefficients from specific studies. In the future, we intend to carry out averaging estimates by metanalytic approaches to obtain the dose-response coefficients from a larger number of studies.

Among the epidemiological field, we analyze only a small yet significant portion of consequences caused by air pollution. Studies already suggest the impacts of air pollution on birth gender (Lichtenfels et al. 2007) and fetal development (Hettfleisch et al. 2017). Another limitation is related to the fact that the ImpactAr tool does not consider different sets of exposure among the population in each city. Air pollution does not affect the population evenly, and there is evidence that suggests that low-income groups tend to experience higher exposures to pollutants due to less favorable environmental living conditions compared to more affluent population groups or areas (Fairburn et al. 2019; Martins et al. 2004; Rivas, Kumar, and HagenZanger 2017) and, therefore, higher impacts on health.

Financial and Economic Stage limitations: As previously mentioned, we have obtained the VSL for Brazil, which measures mortality costs, through the unit transfer methodology. Unfortunately, the unit transfer methodology only acknowledges income and inflation differences between OECD countries (original value transferred) and Brazil. Other differences, which significantly affect the VSL value, include life expectancy and income elasticity, among others. ${ }^{24}$
Furthermore, the tool acknowledges future inflation for the long-run analysis (30 years) through a discount rate, but income growth is not included in the analysis, as we believed the different methodologies used to calculate it could raise strong controversy. This has the potential to underestimate the financial and economic results, as the income is kept at 2018 levels.

Overall limitations: Our tool only fits four Brazilian cities: São Paulo, Rio de Janeiro, Belo Horizonte, and Niterói. Due to the methodology used and the size of the input data required to add more cities, such as new PM FCMs and the number of deaths and hospitalizations recommended. Also, the adoption of ImpactAr for non-Brazilian cities is particularly discouraged because almost all epidemiological parameters embedded in it were retrieved from Brazilian studies. ${ }^{25}$

At last, we acknowledge the need for caution when using ImpactAr tool results. It is important to note that we use a chain process of calculus to measure $\mathrm{PM}_{10}$ and $\mathrm{PM}_{2.5}$ impacts, meaning that we can assert that the final results carry the aggregate errors of each stage's calculation-namely, environmental, epidemiological, and financial and economic. Unfortunately, we are unable to evaluate whether these uncertainties would potentially increase or diminish the results provided by the tool. Hence, the quantitative outputs provided by the ImpactAr tool must be interpreted as estimates that indicate the existence of the impacts, costs, and their respective magnitude in the analyzed cities; they are not an expression of the exact values of epidemiological cases and costs related to the fleet's renewal in terms of $\mathrm{PM}_{2.5}$ and $\mathrm{PM}_{10}$ variations.

Bearing the previous limitations and uncertainties in mind, however, the ImpactAr tool comprises a robust model for measuring air pollution impacts, developed using the state-of-the-art methodologies and most credible databases currently applied among the academic field. The consequences of changes in air pollution levels on health and economy are continuously addressed by empirical studies, and, in this sense, the ImpactAr tool provides an important insight to address such matters in the context of these Brazilian cities. 


\section{PILOT TEST ANALYSIS}

The aim of this section is to provide the readers with a better understanding of the tool's outputs by performing a simulation of an urban bus fleet renewal project for the city of São Paulo. This city is the largest city in Brazil in terms of population and economic activity. With $\mathbf{1 2 . 2}$ million inhabitants, São Paulo accounts for 5.8 percent of Brazil's population, and it is responsible for 11 percent of the national GDP. ${ }^{26}$ It also has the biggest vehicle fleet of the country, reaching 8 percent of total national fleet ${ }^{27}$ with around 9 million vehicles (Detran SP 2019). In this scenario, air pollution is an evident externality in the city, and transport is its main cause.

In January 2018, the municipality implemented a long-term target to reduce the greenhouse gas (GHG) emissions and air pollutants generated by its collective transport fleet in 20 years. ${ }^{28}$ The law settled specific targets of reduction for different air pollutants and GHGs, for instance, $\mathrm{PM}$, carbon dioxide $\left(\mathrm{CO}_{2}\right)$, and nitrogen oxides (NOx). Particularly for PM, the law stipulates a minimum decrease of 95 percent in 20 years from the validity of the law (2038) compared to the 2016 levels (Prefeitura do Município de São Paulo 2018b, subsection IV of article 50).

\section{Table 6 | Scenario 0 (Current Fleet) Inputs: Location in the ImpactAr tool-Project Stage Spreadsheet}

\begin{tabular}{l|l|r|r|}
\hline \multicolumn{3}{|l|}{ CURRENT FLEET } \\
\hline $\begin{array}{l}\text { TYPE OF } \\
\text { BUS }\end{array}$ & TECHNOLOGY & $\begin{array}{l}\text { NUMBER } \\
\text { OF BUSES }\end{array}$ & $\begin{array}{l}\text { ANNUAL } \\
\text { TRAVELE } \\
\text { DISTANCE (KM) }\end{array}$ \\
\hline Bus 1 & Euro III & 7,739 & 63,102 \\
\hline Bus 2 & Euro V & 6,756 & 63,102 \\
\hline Bus 3 & Trolleybus & 201 & 63,102 \\
\hline Bus 4 & Euro VI & 0 & 0 \\
\hline Bus 5 & Euro VI & 0 & 0 \\
\hline
\end{tabular}

Source: WRI authors,
The simulation in the ImpactAr tool is based on the described target for PM reductions in São Paulo. As the target is based on the percentage of emissions reduction, rather than on a profile change in the fleet technology, WRI Brasil determined ad hoc the number of buses of each technology that achieves the 95 percent of reduction in PM emissions, maintaining the total number of buses. The constructed scenario focused on a large increase in the electric fleet, a modest rise in the trolleybus fleet, ${ }^{29}$ and a large reduction in the most pollutant type of technology, Euro III and Euro V. The current fleet (scenario o) and the projected fleet (scenario 1) data inputs for the test are described in Tables 6 and 7.

It is worth noting that the simulation used the values of the emissions factor and the average fuel efficiency provided in the tool by default.

Table 7 | Scenario 1 (Projected Fleet) Inputs: Location in the ImpactAr Tool-Project Stage Spreadsheet

\begin{tabular}{|c|c|c|c|}
\hline \multicolumn{4}{|c|}{ PROJECTED FLEET } \\
\hline $\begin{array}{l}\text { TYPE OF } \\
\text { BUS }\end{array}$ & TECHNOLOGY & $\begin{array}{l}\text { NUMBER } \\
\text { OF BUSES }\end{array}$ & $\begin{array}{l}\text { ANNUAL } \\
\text { TRAVELED } \\
\text { DISTANCE (KM) }\end{array}$ \\
\hline Bus 1 & Euro III & 330 & 63,102 \\
\hline Bus 2 & Euro V & 566 & 63,102 \\
\hline Bus 3 & Trolleybus & 250 & 63,102 \\
\hline Bus 4 & Electric & 13,550 & 63,102 \\
\hline Bus 5 & Euro VI & 0 & 0 \\
\hline
\end{tabular}

Source: WRI authors. 


\subsection{Test Results}

Considering only the impacts of $\mathrm{PM}_{2.5}$, the pollutant with the largest impacts on human health, the implementation of the 95 percent of PM reduction target in São Paulo has the potential to avoid approximately 95 cases of illness and 4 deaths in the first year, reaching around 3,171 cases of illnesses and 141 deaths in 30 years..$^{30}$ In terms of working days lost due to hospitalizations, in one year, about 647 work absences would be avoided, whereas in 30 years this number rises to 22,601 work absences avoided. These impacts collectively represent a potential savings of about $\mathrm{R} \$ 5$ million regarding the morbidity costs and $\mathrm{R} \$ 300$ million regarding the mortality costs, both in the long run.
These and other estimates are presented in Table 8 and are analyzed in more detail in the following subsections.

\subsubsection{Environmental Results}

Table 9 and Figures 5 and 6 show the reduction in emissions and concentration levels in one year due to the technical solution implemented. Units are measured in tons for emissions levels and $\mu \mathrm{g} / \mathrm{m}^{3}$ for concentration levels. The proposed fleet's renewal would result in a drop in emissions of about 140 tons of $\mathrm{PM}_{10}$ and 98 tons of $\mathrm{PM}_{2.5}$ compared to the levels of 2016, which represents approximately a 95 percent reduction as proposed in municipal law $16.802 / 2018$. Changes in concentration levels would reduce around $0.1535 \mu \mathrm{g} / \mathrm{m}^{3}$ and $0.1075 \mu \mathrm{g} / \mathrm{m}^{3}$, for $\mathrm{PM}_{10}$ and $\mathrm{PM}_{2.5}$, respectively.

Table 8 | Main Results of the Second Simulation: Location in the ImpactAr Tool - Main Results Spreadsheet

\begin{tabular}{|c|c|c|c|c|c|}
\hline \multirow{2}{*}{ STAGE } & \multirow{2}{*}{ SUBSTAGE } & \multicolumn{2}{|c|}{$\mathrm{PM}_{2.5}$} & \multicolumn{2}{|c|}{$\mathrm{PM}_{10}$} \\
\hline & & 1 YEAR & 30 YEARS & 1 YEAR & 30 YEARS \\
\hline \multirow{2}{*}{ ENVIRONMENTAL } & Emissions (tons/year) & \multicolumn{2}{|c|}{-97.7} & \multicolumn{2}{|c|}{-139.6} \\
\hline & Concentration $\left(\mu \mathrm{g} / \mathrm{m}^{3}\right)$ & \multicolumn{2}{|c|}{-0.1075} & \multicolumn{2}{|c|}{-0.1535} \\
\hline \multirow{3}{*}{ EPIDEMIOLOGICAL } & $\begin{array}{l}\text { Morbidity cases } \\
\text { Number of disease } \\
\text { cases }\end{array}$ & -95 & $-3,171$ & -40 & $-1,443$ \\
\hline & $\begin{array}{l}\text { Mortality cases } \\
\text { Number of fatalities }\end{array}$ & -4 & -141 & -2 & -89 \\
\hline & $\begin{array}{l}\text { Working days lost due } \\
\text { to hospitalization stays }\end{array}$ & -647 & $-22,601$ & -315 & $-11,544$ \\
\hline \multirow{2}{*}{$\begin{array}{l}\text { FINANCIAL AND } \\
\text { ECONOMIC }\end{array}$} & $\begin{array}{l}\text { Morbidity costs } \\
\text { Cost of illness }(R \$)\end{array}$ & $-296,528,95$ & $-5,394,473.45$ & $-157,494.47$ & $-2,901,726.76$ \\
\hline & $\begin{array}{l}\text { Mortality costs } \\
\text { Value of statistical life }(\mathrm{R} \$)\end{array}$ & $-16,741,814,29$ & $-300,947,149.42$ & $-8,764,888.26$ & $-175,814,062.86$ \\
\hline
\end{tabular}

Source: WRI authors.

Table 9 | Main Environmental Results: Location in the ImpactAr Tool-Environmental Stage Spreadsheet

\begin{tabular}{|c|c|c|c|c|c|}
\hline & POLLUTANT & $\begin{array}{l}\text { CURRENT FLEET } \\
\text { (SCENARIO 0) }\end{array}$ & $\begin{array}{l}\text { PROJECTED FLEET } \\
\text { (SCENARIO 1) }\end{array}$ & VARIATION & VARIATION (\%) \\
\hline \multirow{2}{*}{$\begin{array}{l}\text { EMISSIONS } \\
\text { (TONS/YEAR) }\end{array}$} & $\mathrm{PM}_{2.5}$ & 102.84 & 5.1 & -97.69 & -95 \\
\hline & $\mathrm{PM}_{10}$ & 146.91 & 7.4 & -139.55 & -95 \\
\hline \multirow{2}{*}{$\begin{array}{l}\text { CONCENTRATION } \\
\left(\mu \mathrm{G} / \mathrm{M}^{3}\right)\end{array}$} & $\mathrm{PM}_{2.5}$ & 0.1131 & 0.0057 & -0.1075 & -95 \\
\hline & $\mathrm{PM}_{10}$ & 0.1616 & 0.0081 & -0.1535 & -95 \\
\hline
\end{tabular}

Source: WRI authors. 
Figure 5 | Emissions Reductions: Location in the ImpactAr Tool-Environmental Stage Spreadsheet

Annual emissions variations (tons/year)

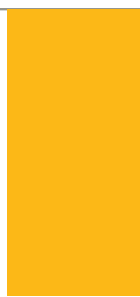

$-97.69$

Source: ImpactAr tool.

\subsubsection{Epidemiological Results}

Table 10 and Figures 7, 8, 9, and 10 present the numbers of morbidity and mortality cases avoided according to the long-run and short-run analyses of the ImpactAr tool, measured for each pollutant and type of disease. The reductions in $\mathrm{PM}_{10}$ and $\mathrm{PM}_{2.5}$ emissions are reflected in the number of mortality and morbidity cases related to air pollution. For total cumulative effects provided
Figure 6 | Concentration Reduction: Location in the ImpactAr Tool-Environmental Stage Spreadsheet

\section{Annual concentration variation $\left(\mu \mathrm{g} / \mathrm{m}^{3}\right)$}

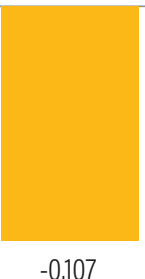

$\mathrm{PM}_{2.5} \quad \mathrm{PM}_{10}$

Source: ImpactAr tool.

by the long-run analysis (30 years), reductions in $\mathrm{PM}_{2.5}$ concentration levels would avoid approximately 3,171 hospitalizations, whereas reductions in $\mathrm{PM}_{10}$ concentration levels would avoid about 1,443. As for mortality outcomes, 141 cases would be avoided due to the drops in PM2 ${ }_{5}$ levels and 89 cases due to the drops in $\mathrm{PM}_{10}$ levels, both for the 30-year analysis.

Table 10 | Main Epidemiological Results: Location in the ImpactAr Tool-Epidemiological Stage Spreadsheet

\begin{tabular}{|c|c|c|c|c|c|}
\hline \multicolumn{6}{|c|}{ VARIATION OF FATAL AND NONFATAL CASES } \\
\hline $\begin{array}{l}\text { TYPE OF HEALTH } \\
\text { IMPACT }\end{array}$ & POLLUTANT & $\begin{array}{l}\text { CURRENT FLEET } \\
\text { (SCENARIO 0) }\end{array}$ & $\begin{array}{l}\text { PROJECTED FLEET } \\
\text { (SCENARIO 1) }\end{array}$ & VARIATION & VARIATION (\%) \\
\hline \multirow{4}{*}{ MORBIDITY } & \multirow{2}{*}{$\mathrm{PM}_{2.5}$} & 1 & -35 & -60 & -95 \\
\hline & & 30 & $-1,296$ & $-1,875$ & $-3,171$ \\
\hline & \multirow{2}{*}{$\mathrm{PM}_{10}$} & 1 & -23 & -17 & -40 \\
\hline & & 30 & -821 & -622 & $-1,443$ \\
\hline \multirow{4}{*}{ MORTALITY } & \multirow{2}{*}{$\mathrm{PM}_{2.5}$} & 1 & -3 & -1 & -4 \\
\hline & & 30 & -108 & -33 & -141 \\
\hline & \multirow{2}{*}{$\mathrm{PM}_{10}$} & 1 & 0 & -2 & -2 \\
\hline & & 30 & -1 & -87 & -88 \\
\hline
\end{tabular}

Source: WRI authors. 
Figure 7 | Avoided Morbidity in One Year: Location in the ImpactAr Tool-Epidemiological Stage Spreadsheet

\section{Variation on morbidity cases - 1 year}
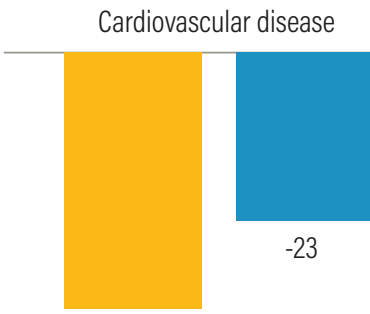

$-23$

$-35$

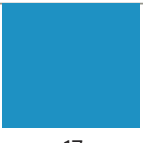

$-17$
Respiratory disease

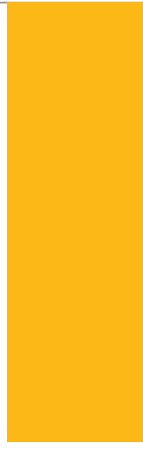

$-60$

$\mathrm{PM}_{2.5} \quad \mathrm{PM}_{10}$

Source: ImpactAr tool.

Figure 9 | Avoided Mortality Cases in One Year: Location in the ImpactAr Tool-Epidemiological Stage Spreadsheet

\section{Variation on mortality cases - 1 year}

Cardiovascular disease

Respiratory disease

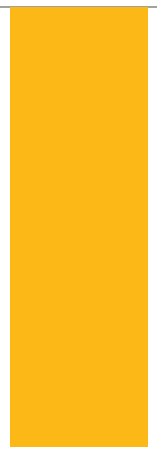

0
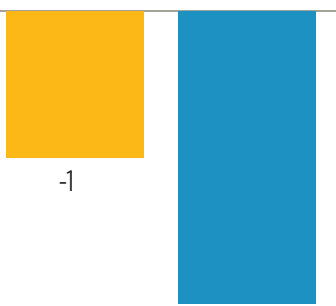

$-2$

$\mathrm{PM}_{2.5} \quad \mathrm{PM}_{10}$

Source: ImpactAr tool.

The numbers of avoided fatalities were significantly lower than those for avoided hospitalizations. This result was already expected because C-Rs had already shown that the impact of changes in concentration levels was much higher for nonfatal diseases than for fatal diseases. For both mortality and morbidity, $\mathrm{PM}_{2.5}$ impacts were significantly larger when compared to $\mathrm{PM}_{10}$ figures.

Figure 8 | Avoided Morbidity in 30 years: Location in the ImpactAr Tool-Epidemiological Stage Spreadsheet

\section{Variation on morbidity cases - 30 years}

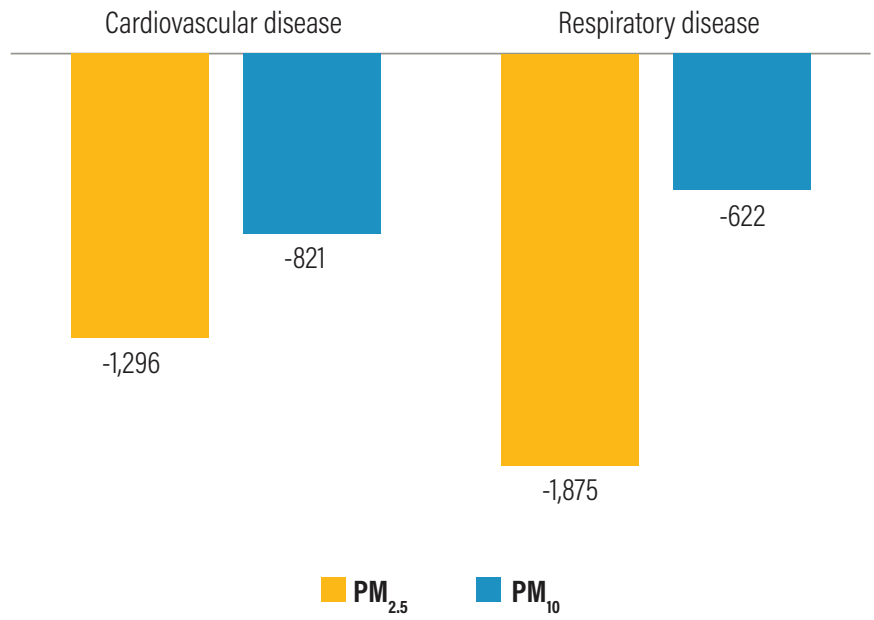

Source: ImpactAr tool.

Figure 10 | Avoided Mortality Cases in 30 Years: Location in the ImpactAr ToolEpidemiological Stage Spreadsheet

\section{Variation on mortality cases - 30 years}

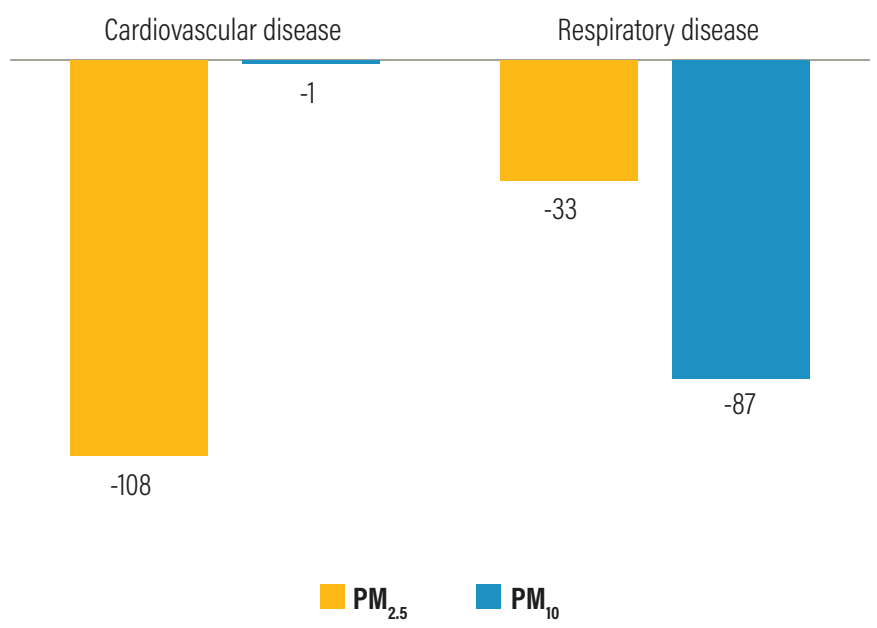

Source: ImpactAr tool. 


\subsubsection{Financial and Economic Results}

Tables 11 and 12 show the costs avoided related to the variation in the numbers of mortality and morbidity cases linked to the fleet's renewal. It is worth noting that mortality costs are of economic nature, whereas morbidity costs are of financial nature. This happens due to the different methodology of measuring each health impact type: mortality costs are calculated through the VSL, and morbidity costs are measured through the COI methodology.
Figures 11 and 12 summarize savings in terms of hospitalization costs and income losses as a result of the decrease in the number of nonfatal diseases. Again, analysis cover the impacts of $\mathrm{PM}_{10}$ and $\mathrm{PM}_{2.5}$, short-run and long-run analyses for each health endpoint. As expected, cardiovascular diseases presented the larger share of the costs avoided. The cumulative effects of avoided costs in 30 years totaled $\mathrm{R} \$ 5,394,473$ for $\mathrm{PM}_{2.5}$ and $\mathrm{R} \$ 2,901,726$. for $\mathrm{PM}_{10}$. According to the short-run analysis (1 year), $\mathrm{PM}_{2.5}$ reductions would avoid costs of around $\mathrm{R} \$ 296,528$, and $\mathrm{PM}_{10}$ reductions would avoid costs of around $\mathrm{R} \$ 157,494$.

Table 11 | Total Cost of Morbidity: Location in the ImpactAr Tool-Financial and Economic Stage Spreadsheet

\begin{tabular}{|l|l|l|l|l|c|}
\hline \multicolumn{7}{|c|}{ VARIATION ON TOTAL MORBIDITY COSTS } \\
\hline & POLLUTANT & $\begin{array}{l}\text { PERIOD } \\
\text { (YEARS) }\end{array}$ & $\begin{array}{l}\text { CARDIOVASCULAR } \\
\text { DISEASES (RS) }\end{array}$ & $\begin{array}{l}\text { RESPIRATORY } \\
\text { DISEASES (RS) }\end{array}$ & TOTAL (RS) \\
\hline & & 1 & $-178,277$ & $-118,251$ \\
\hline MORBIDITY & $\mathrm{PM}_{2.5}$ & & $-296,528$ & $-2,056,771$ \\
\hline
\end{tabular}

Source: WRI authors.

Table 12 | Total Cost of Mortality: Location in the ImpactAr Tool-Financial and Economic Stage Spreadsheet

\begin{tabular}{|c|c|c|c|c|c|}
\hline \multicolumn{6}{|c|}{ VARIATION ON TOTAL MORTALITY COSTS } \\
\hline \multirow{5}{*}{ MORTALITY } & POLLUTANT & $\begin{array}{l}\text { PERIOD } \\
\text { (YEARS) }\end{array}$ & $\begin{array}{l}\text { CARDIOVASCULAR } \\
\text { DISEASES (RS) }\end{array}$ & $\begin{array}{l}\text { RESPIRATORY } \\
\text { DISEASES (RS) }\end{array}$ & TOTAL (RS) \\
\hline & \multirow{2}{*}{$\mathrm{PM}_{2.5}$} & 1 & $-12,521,006$ & $-4,220,807$ & $-16,741,814$ \\
\hline & & 30 & $-228,191,287$ & $-72,755,862$ & $-300,947,149$ \\
\hline & \multirow[b]{2}{*}{$\mathrm{PM}_{10}$} & 1 & $-152,874$ & $-8,612,014$ & $-8,764,888$ \\
\hline & & 30 & $-2,944,259$ & $-172,869,803$ & $-175,814,062$ \\
\hline
\end{tabular}

Source: WRI authors. 
Figure 11 Avoided Morbidity Costs in One Year: Location in the ImpactAr Tool-Financial and Economic Stage Spreadsheet

Variation on total morbidity costs - 1 year (RS)

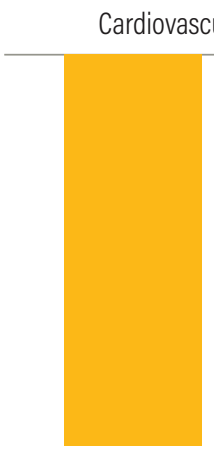

Respiratory disease

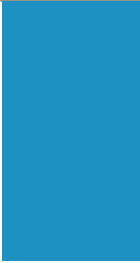

$-118,251$

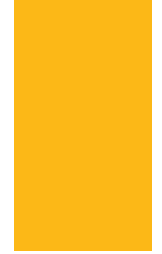

$-114,573$

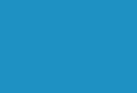

$-42,921$

$-178,278$

$\mathrm{PM}_{2.5} \quad \mathrm{PM}_{10}$

Source: ImpactAr tool.

The mortality economic costs avoided represented the largest figures in the Financial and Economic Stage of the results provided by the ImpactAr tool. This can be explained by the intended variables covered by the methodology. The idea is to provide a measure, in terms of Brazilian reals, of the welfare losses avoided due to variations in air pollution levels. The values, however, do not have an accountant nature and therefore cannot be addressed as financial costs.

Figure 13 | Avoided Mortality Costs in One Year: Location in the ImpactAr Tool-Financial and Economic Spreadsheet

Variation on mortality costs - 1 year (RS)

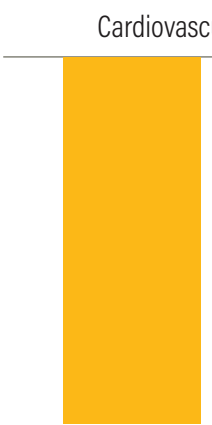

Respiratory disease
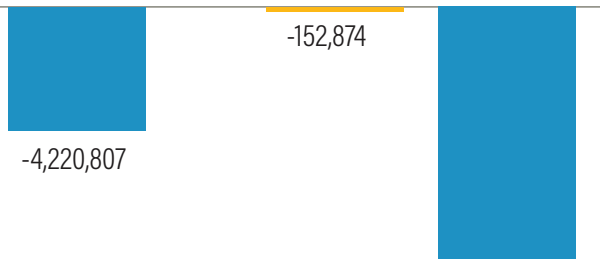

$-8,612,014$

$-12,521,007$
Figure 12 | Avoided Morbidity Costs in 30 Years: Location in the ImpactAr Tool-Financial and Economic Stage Spreadsheet

Variation on total morbidity costs - 30 years (RS)

Cardiovascular disease

Respiratory disease

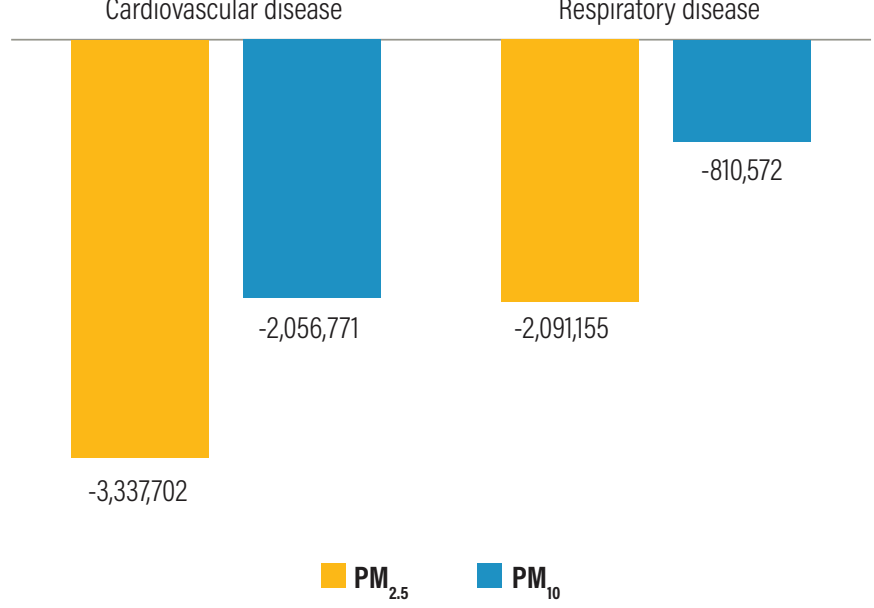

Source: ImpactAr tool.

Figures 13 and 14 illustrate the mortality costs avoided as a result of the technical solution adopted for São Paulo's urban bus fleet. The total avoided economic/welfare losses related to mortality reached $\mathrm{R} \$ 300,947,149$ for $\mathrm{PM}_{2.5}$ reductions and $\mathrm{R} \$ 175,814,062$ for $\mathrm{PM}_{10}$ reductions in 30 years.

Figure 14 | Avoided Mortality Costs in 30 Years: Location in the ImpactAr Tool-Financial and Economic Spreadsheet

\section{Variation on mortality costs - 30 years (RS)}

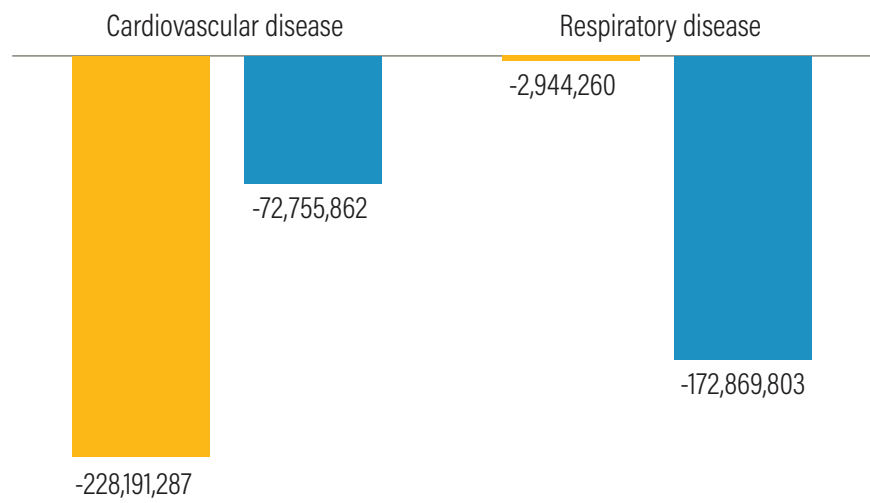

$\mathrm{PM}_{2.5} \quad \mathrm{PM}_{10}$

Source: ImpactAr tool. 


\subsubsection{Comparative Analysis}

Considering the costs that would be avoided due to the reduction of $\mathrm{PM}_{2.5}$ and $\mathrm{PM}_{10}$ emissions, the ImpactAr tool provided a comparative analysis with selected economic indicators for the municipality of São Paulo. It analyzed how much the monetary outcomes, as a consequence of the proposed change in the bus fleet, would represent in terms of the municipal GDP, municipal health, and hospitalization expenditures in 2018, and how many public hospitalizations could be provided to the population, according to the financial savings. This information is presented in Table 13.

In one year, the total avoided COI (direct and indirect costs summed) is almost zero compared to the annual GDP and total health expenditure of São Paulo. However, the savings due to nonfatal diseases could provide São Paulo's population with an additional 107 hospitalizations surplus, in the case of $\mathrm{PM}_{2.5}$ reductions, and 57 in the case of $\mathrm{PM}_{10}$ reductions, considering the average unit price of public and private hospitalizations in 2018 from all causes in São Paulo. Mortality costs, in turn, would represent around 0.012 percent and 0.006 percent of the municipal GDP, for $\mathrm{PM}_{2.5}$ and $\mathrm{PM}_{10}$ in one year, respectively.

If we consider the cumulative impact of avoided costs for 30 years and compare it with the same annual indicators, the 30-year avoided cost of mortality could reach about 0.23 percent and 0.13 percent of São Paulo's GDP, for $\mathrm{PM}_{2.5}$ and $\mathrm{PM}_{10}$, respectively.

Summing up the COI for 30 years, the values remain low, being about 0.004 percent for $\mathrm{PM}_{2.5}$ and 0.002 percent for $\mathrm{PM}_{10}$ of municipal GDP. As for the relation of morbidity avoided costs and the municipal health and hospitalization expenditures of $2018, \mathrm{PM}_{2.5}$ associated costs represented, respectively, 0.05 percent and 0.64 percent, and $\mathrm{PM}_{10}$ associated costs around 0.03 percent and 0.34 percent. In terms of additional hospitalizations due to morbidity savings, the numbers reach 1,943 for $\mathrm{PM}_{2.5}$ and 1,045 hospitalizations that could be provided to the population.

Table 13 | Comparative Analysis: Main Results Spreadsheet

\begin{tabular}{|c|c|c|c|c|c|c|c|c|c|c|c|}
\hline \multirow[t]{2}{*}{ PERIOD } & \multirow[t]{2}{*}{ SUBSTAGE } & \multicolumn{2}{|c|}{$\begin{array}{l}\text { TOTAL COSTS } \\
\text { VARIATION (RS) }\end{array}$} & \multicolumn{2}{|c|}{$\begin{array}{l}\text { TOTAL COSTS } \\
\text { VARIATION/GDPm } \\
(\%)\end{array}$} & \multicolumn{2}{|c|}{$\begin{array}{l}\text { TOTAL COSTS } \\
\text { VARIATION / } \\
\text { ANNUAL HEALTH } \\
\text { EXPENDITURE (\%) }\end{array}$} & \multicolumn{2}{|c|}{$\begin{array}{l}\text { TOTAL COSTS } \\
\text { VARIATION / } \\
\text { ANNUAL HOSPITAL } \\
\text { EXPENDITURE (\%) }\end{array}$} & \multicolumn{2}{|c|}{$\begin{array}{l}\text { NUMBER OF } \\
\text { HOSPITALIZATIONS } \\
\text { DUE TO SAVING/ } \\
\text { COSTS OF THE FLEET } \\
\text { CHANGES }(\%) \\
\end{array}$} \\
\hline & & $\mathrm{PM}_{2.5}$ & $P M_{10}$ & $\mathrm{PM}_{2.5}$ & $P M_{10}$ & $\mathrm{PM}_{2.5}$ & $P M_{10}$ & $\mathrm{PM}_{2.5}$ & $\mathrm{PM}_{10}$ & $\mathrm{PM}_{2.5}$ & $P M_{10}$ \\
\hline \multirow{2}{*}{1 YEAR } & Morbidity & $-296,528.95$ & $-157,494.47$ & 0.00022947 & 0.0001219 & 0.00300284 & 0.00159489 & 0.03547773 & 0.01884317 & 107 & 57 \\
\hline & Mortality & $-16,741,814.29$ & $-8,764,888.26$ & 0.01295592 & 0.0067828 & $*$ & * & * & * & * & * \\
\hline \multirow{2}{*}{30 YEARS } & Morbidity & $-5,394,473.45$ & $-2,901,726.76$ & 0.0041746 & 0.0022455 & 0.05462784 & 0.02938471 & 0.64541308 & 0.34717242 & 1,943 & 1,045 \\
\hline & Mortality & $-300,947,149.42$ & $-175,814,062,86$ & 0.23289267 & 0.1360565 & $*$ & $*$ & $*$ & $*$ & * & * \\
\hline
\end{tabular}

Notes: GDPm = municipal gross domestic product.

*For the costs associated with mortality, the value of statistical life (VSL) methodology was used. VSL is an estimate of how much people are willing to pay to reduce the risk of death, taking into account issues such as suffering and discomfort. Therefore, this cost represents more than the financial impacts of mortality and cannot be compared with financial variables such as health expenditures.

Source: WRI authors. 


\subsubsection{Comparative Analysis using Linking function 2.1 and Linking function 2.2}

The results presented above were developed based on the PM FCM obtained through the Linking function 2.2. In this section, for illustrative and comparative purposes, it is also shown the results obtained through Linking function 2.1 (Table 14). The same data inputs, previously described, were considered for the current fleet and the projected fleet.

For the city of São Paulo, the simulation performed using the methodology described in Linking function 2.2 resulted in a $23 \%$ reduction in the PM FCM. It is possible to verify that, after the substage of concentration estimation, the indicators observed show the same percentage reduction as the PM FCM, since there is a linear relationship between this variable and the results. This pattern is verified for $\mathrm{PM}_{10}$.
With this, it is possible to conclude that when using the Linking function 2.2, there is a reduction in the absolute number of cases of morbidity and mortality and, consequently, in costs. It is important to note that this reduction in the absolute number is valid for the cities analyzed and considering the technical parameters described in the simulation, but not for all cases. Also, since they are econometric models that have aggregated errors in each step, which are not measured (see section 5. Limitations and uncertainties), it can be considered that the results of two different linking functions are relatively close. As mentioned in the Methodology section, the variation observed in the results can be due to differences in the distribution of PM emissions and due to the period evaluated for each simulation.

Table 14 | Comparative Analysis: Main Results for $\mathrm{PM}_{2.5}$ estimated using Linking functions 2.1 and 2.2

\begin{tabular}{|c|c|c|c|c|c|c|c|}
\hline \multirow{2}{*}{ STAGE } & \multirow{2}{*}{ SUBSTAGE } & \multicolumn{2}{|c|}{$\mathrm{PM}_{2.5}$} & \multicolumn{2}{|c|}{$\mathrm{PM}_{10}$} & \multicolumn{2}{|c|}{$\Delta$ (absolute value) } \\
\hline & & 1 YEAR & 30 YEARS & 1 YEAR & 30 YEARS & 1 YEAR & 30 YEARS \\
\hline \multirow{2}{*}{ ENVIRONMENTAL } & Emissions (tons/year) & \multicolumn{2}{|c|}{-97.7} & \multicolumn{2}{|c|}{-97.7} & \multicolumn{2}{|c|}{0} \\
\hline & Concentration $\left(\mu \mathrm{g} / \mathrm{m}^{3}\right)$ & \multicolumn{2}{|c|}{-0.1397} & \multicolumn{2}{|c|}{-0.1075} & \multicolumn{2}{|c|}{0.0322} \\
\hline \multirow{3}{*}{ EPIDEMIOLOGICAL } & $\begin{array}{l}\text { Morbidity cases } \\
\text { Number of disease cases }\end{array}$ & -124 & $4,122.00$ & -95 & $-3,171.00$ & 29 & 952 \\
\hline & $\begin{array}{l}\text { Mortality cases } \\
\text { Number of fatalities }\end{array}$ & -5 & -184 & -4 & -141 & 1 & 42 \\
\hline & $\begin{array}{l}\text { Working days lost due to } \\
\text { hospitalization stays }\end{array}$ & -841 & $-29,383.00$ & -647 & $-22,601.00$ & 194 & 6,782 \\
\hline \multirow{2}{*}{$\begin{array}{l}\text { FINANCIAL AND } \\
\text { ECONOMIC }\end{array}$} & $\begin{array}{l}\text { Morbidity costs } \\
\text { Cost of illness (R\$) }\end{array}$ & $-385,513.51$ & $-7,013,262.75$ & $-296,528.95$ & $-5,394,473,45$ & 88,985 & $1,618,789$ \\
\hline & $\begin{array}{l}\text { Mortality costs } \\
\text { Value of statistical life }(\mathrm{R} \$)\end{array}$ & $21,764,725$ & $-391,237,883$ & $-16,741,814$ & $-300,947,149$ & $5,022,911$ & $90,290,734$ \\
\hline
\end{tabular}

Source: WRI authors, 


\section{FINAL REMARKS AND CONCLUSION}

Air pollution currently imposes one of the most serious threats to a variety of dimensions of human life.

Fighting against air pollution requires the engagement of decision-makers from different sectors and the use of epidemiological, economic, and financial evidence provides a common ground for it (WHO/Europe and OECD 2015). As mentioned before, however, estimating the unobservable costs of air pollution impacts is not a trivial task, as it requires the use of several methodologies that are capable of both isolating the effects of pollutants on health and estimating the costs associated with these diseases.

Through the systematic organization of several existing methodologies applied in national empirical studies, the ImpactAr tool conveys the different stages of the chain process that pollutants go through in one tool. By allying scientific integrity and practicality, the tool is an attempt to provide Brazilian public municipal decisionmakers, as well as politicians, private sector operators, academics, researchers. and the public in general, with (i) a robust tool that models air pollution impacts, (ii) easy access to the advanced methodologies, (iii) maximum ease of use and understanding of the results, and (iv) transparency about the methodology and data used in the process.

By using the ImpactAr tool, estimates on the existence and magnitude of the impacts on health and its related costs of PM caused by changes in the bus fleet can be measured for the cities of São Paulo, Rio de Janeiro, Belo Horizonte, and Niterói. The tool is a first step toward making observable the implicit costs of air pollution in Brazilian cities, after which a deeper research on a caseby-case basis should be carried out. The tool's results can broaden the benefit-cost analysis of transport projects made by their proponents by adding the potential non observable costs of air pollution.
It is important to bear in mind that, although the impacts related to human health are considered the most significant consequences of air pollution, the literature on the matter has strongly suggested that air pollution affects other areas of human life, such as urban vegetation (Amato-Lourenço et al. 2016), real estate values (Carriazo Osorio 2001), and cultural heritage (Watt et al. 2009). Furthermore, air pollution, and, more specifically, the short-lived climate forcers (SLCFs), ${ }^{31}$ are also important contributors to climate change and key challenges because their reduction would have the potential to slow the climate change in the near term (UNEP 2011). Due to limited data and the incipient Brazilian empirical studies on these subjects, we opted not to include such areas, as we would significantly raise the uncertainty of the model, though it is important not to forget that, by broadening the areas of impact, the costs/benefits of a fleet's renewal would certainly increase.

Despite focusing on four Brazilian cities, the aim of the tool is not to be confined to them. In this sense, both ImpactAr and its technical note should be used as a blueprint for other cities to learn and develop their own version of the ImpactAr tool. In the future, more Brazilian cities are expected to be included, depending on the availability of open data. The authors encourage users to provide feedback and recommendations so they can advance both the applicability as well as the accuracy of their results. 


\section{APPENDIX A. IMPACTAR TOOL USER GUIDE AND SPREADSHEET INTERFACES}

This section presents a short user guide (along with the interfaces of specific spreadsheets in the ImpactAr too ${ }^{32}$ ) to help users enter the required and/or optional data and to navigate the main outcomes of the tool. It is worth remembering that ImpactAr was built to maintain maximum ease of use and understanding of the results for users. By following the instructions below, users will be able to fully operate the tool.

\section{A.1 Inserting Optional Data}

After the first two spreadsheets-"Cover" and "User Guide" (presented in Section 3, ImpactAr Tool Structure)-the tool presents the "Optional Inputs" (OPT_INPUTS) spreadsheet (Figure A1). This optional input sheet contains a table that enables users to change the PM emissions factors $(\mathrm{g} / \mathrm{L})$ and average fuel effiency $(\mathrm{L}$ or $\mathrm{kWh} / 100 \mathrm{~km})$ per the technology of the buses. The values available in the model by default are provided in the white cells of the table. The optional value can be filled in the green cells of the table only if the user possesses such data; otherwise, green cells must be kept with N/A value, as the model will provide data by default.

Figure A1 | Interface of the Optional Input Spreadsheet-0PT_INPUTS

\section{OPTIONAL INPUTS}

Instructions: This is an optional input sheet that enables users to change the emissions factor and average fuel consumption per the technology of the buses. The values available in the model by default are provided in the gray cells. Note that you should only fill the optional value in the orange cells if you have the data required. If you do not possess such information, keep the orange with N/A value, as the model will provide data by default.

\begin{tabular}{|c|c|c|c|c|}
\hline Type of Technology & $\begin{array}{c}\text { PM Emissions Factor by } \\
\text { Default (g/L) }\end{array}$ & $\begin{array}{c}\text { Average Fuel Consumption } \\
\text { by Default ( } \mathrm{L} \text { or } \mathrm{kWh} / 100 \\
\mathrm{~km})\end{array}$ & $\begin{array}{l}\text { Optional PM Emissions } \\
\text { Factor Input Data (g/L) }\end{array}$ & $\begin{array}{c}\text { Optional Average Fuel } \\
\text { Consumption Input Data ( } \mathrm{L} \text { or } \\
\mathrm{kWh} / 100 \mathrm{~km})\end{array}$ \\
\hline Euro V & 0.07 & 59.30 & $\mathrm{~N} / \mathrm{A}$ & N/A \\
\hline Euro III & 0.30 & 57.00 & $N / A$ & N/A \\
\hline Electric & 0.00 & 1.30 & $\mathrm{~N} / \mathrm{A}$ & N/A \\
\hline Hybrid & 0.04 & 41.50 & $N / A$ & N/A \\
\hline Trolleybus & 0.00 & 2.29 & $\mathrm{~N} / \mathrm{A}$ & N/A \\
\hline Biodiesel B20 & 0.06 & 57.00 & N/A & N/A \\
\hline Euro VI & 0.03 & 59.30 & $N / A$ & N/A \\
\hline
\end{tabular}

Source: ImpactAr tool.

\section{A.2 Inserting Required Data}

After the 0ptional Inputs spreadsheet is the "Project" (1_PROJECT) spreadsheet. This is the only required input section. To start the simulation, the user should follow the steps provided in this spreadsheet.

Step 1: Choose your city. The user must first select the city of interest: São Paulo, Rio de Janeiro, Belo Horizonte, or Niteroi-by filtering the cell. Please note that entering the correct city is paramount to getting the correct results because the databases used to calculate the impacts for each city vary significantly and, therefore, the outcomes as well.

\section{Step 2: Do you have information regarding your current and} projected fleet of buses and/or trucks? Before users are required to input information about the current and projected bus fleets, there is a cell asking whether they possess such data. If users possess the data, they are instructed to remain in the same spreadsheet and complete the following two tables with the data (see Step 3 below). If users do not possess the required information, they are instructed to press a cell, which leads them directly to the additional step in the same spreadsheet (see Additional Step).
Step 3: Fill in the data regarding your current and your projected fleet. Fleet data must be entered in the input worksheet (Project spreadsheet) twice: once for the city's current bus fleet and once for the city's projected (future) bus fleet. Data required include the

- number of buses (current and projected fleet);

- type of technology (current and projected fleet); and

- average annual travel distance (km) per bus (current and projected fleet).

Additional Step: Fill in environmental data. Note you should only fill these cells if you haven't filled the data required in Step 3, otherwise, keep the annual value of the table "Input Data" as " 0 ." This step is only required for users who have not filled in the data about the urban bus fleet (both current and projected). Here, any value of annual emissions or concentration levels of $\mathrm{PM}_{2.5}$ or $\mathrm{PM}_{10}$ can be inputted, and the tool will measure the epidemiological, financial, and economic impacts in the following spreadsheets. In this case, the values entered will represent annual variations on air pollution levels linked to the transport sector. This means that the tool will assume that air pollution levels for scenario 1 represent the values inputted by the user, and the air pollution levels for scenario 0 will be equal to zero. 
It should be noted that if users enter the data in the Additional Step section, the inputs inserted for the measurement of the impacts of fleet renewal will not be considered. In this sense, users should always keep the annual value of the Input Data table in the Additional Step as " 0 " if they want to measure the impacts of fleet renewal.
In order to present the interface of the Project Stage, we have broken the spreadsheet into Figure A2, which presents the section of the spreadsheet with Steps 1, 2, and 3; and Figure A3, which presents the section of the spreadsheet with the Additional Step.

Figure A2 | Interface of the Project Stage Spreadsheet: Steps 1, 2, and 3-1_PROJECT

Instructions: This is a required input sheet. Please pay attention to each step. Gray cells are to be filtered, orange cells are to be filled, and green cells are optional inputs

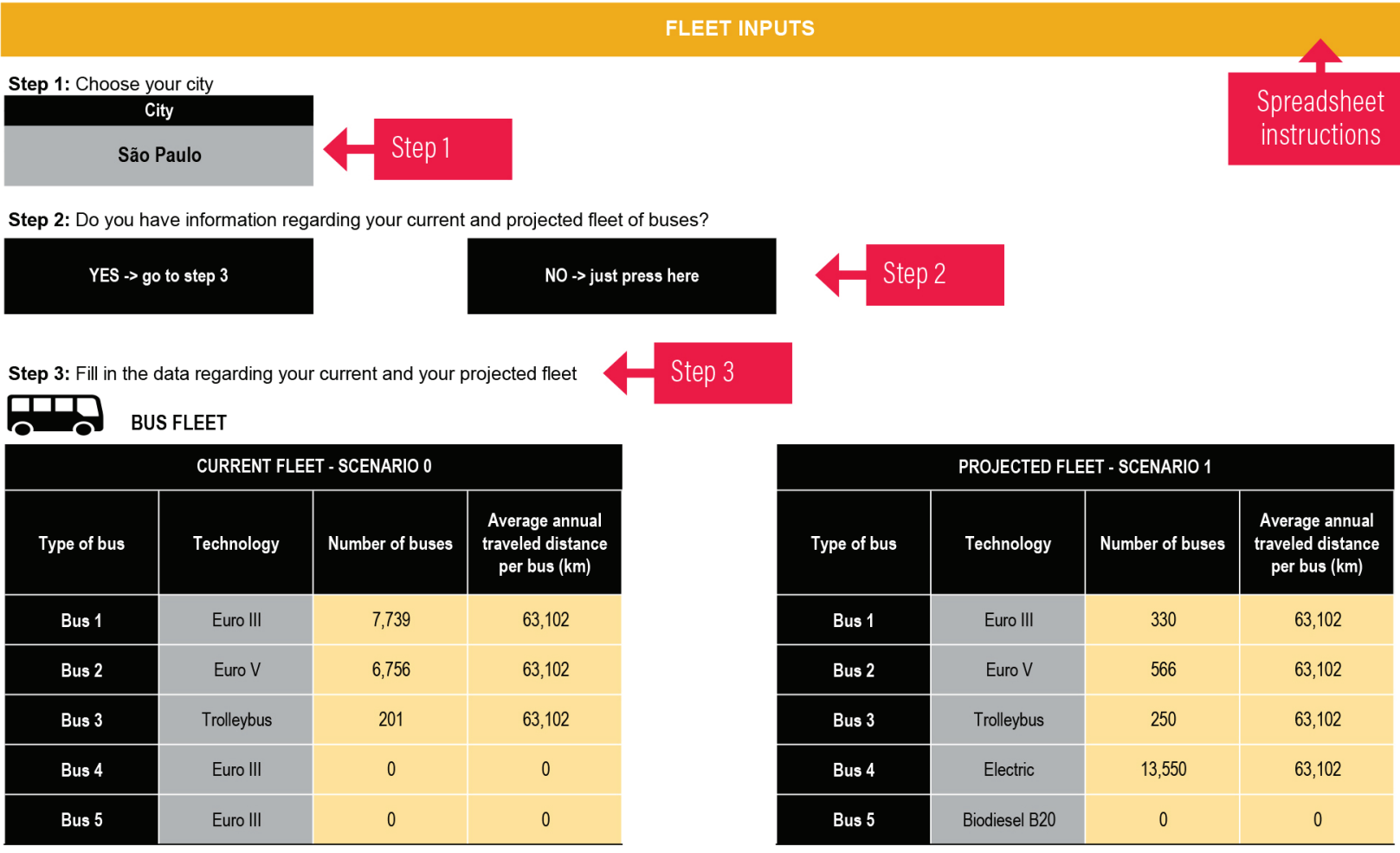

Source: ImpactAr tool.

Figure A3 | Interface of Project Stage Spreadsheet: Additional Step-1_PR0JECT

Additional Step: Note, you should only fill these cells if you haven't filled the data required in Step 3, otherwise, keep the annual value of the table "Input Data" as " 0 ".

If you do not possess fleet data to enter, you can input any value of annual emissions or concentration levels of $\mathrm{PM}_{2.5}$ or $\mathrm{PM}_{10}$ in this subsection, and the tool will measure the epidemiological, financial, and economic impacts in the following spreadsheets. In this case, the values entered will represent annual variations on air pollution levels. This means that the tool will assume that air pollution levels for scenario 1 represent the values inputted by the user, and the air pollution levels for scenario 0 will be equal to zero.
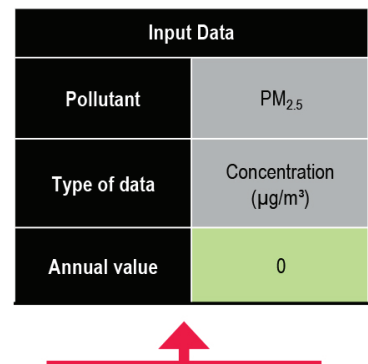

Table to input

environmental data

Source: ImpactAr tool.

\begin{tabular}{|c|c|c|}
\hline \multicolumn{3}{|c|}{ Main Results from Input Data - Annual Values } \\
\hline & $\begin{array}{c}\text { Particulate matter } \\
\mathbf{2 . 5}\left(\mathrm{PM}_{25}\right)\end{array}$ & $\begin{array}{c}\text { Particulate matter } \\
\mathbf{1 0}\left(\mathrm{PM}_{10}\right)\end{array}$ \\
\hline $\begin{array}{c}\text { Emissions } \\
\text { (tons/year) }\end{array}$ & $\mathrm{N} / \mathrm{A}$ & $\mathrm{N} / \mathrm{A}$ \\
\hline $\begin{array}{c}\text { Concentration } \\
\left(\boldsymbol{\mu g} / \mathrm{m}^{3}\right)\end{array}$ & $\mathrm{N} / \mathrm{A}$ \\
\hline & \multicolumn{2}{|c}{$\mathrm{N} / \mathrm{A}$} \\
\hline & \multicolumn{2}{|c|}{$\begin{array}{c}\text { Environmental results } \\
\text { of the inputted data }\end{array}$} \\
\end{tabular}




\section{A.3 Analyzing the Results}

After filling in either the information required for the fleet renewal or the environmental data, no new data will be required and the user can navigate the results of the simulation's in the following five spreadsheets. Each spreadsheet or section contains a summary analysis of the main results per stage (environmental, epidemiological, and financialeconomic) and a detailed section with specific outcomes. Different tables and different graphs that can be filtered are provided in each section and all analyses cover 1-year impacts (short-run analysis) and 30-year impacts (long-run analysis) of the variation of $\mathrm{PM}_{10}$ and $\mathrm{PM}_{2.5}$ levels. If the level of $\mathrm{PM}_{2.5}$ and $\mathrm{PM}_{10}$ emissions or concentration decrease (increase) as a result of the differences between the current and the projected fleet, all results will be given as negative (positive), meaning a reduction (growth) in emissions and concentration levels, epidemiological cases, and financial and economic costs. All the results will be given as negative if the user provided input information in the Additional Step section of the Project spreadsheet, as the tool will assume that air pollution levels for scenario 1 represent the values inputted by the user, and the air pollution levels for scenario 0 will be equal to zero. Below you can find details on each spreadsheet's results section.
Analysis of the environmental results spreadsheet (2 ENVIRONMENTAL_STAGE). In the first part of this section, the user can analyze the main environmental results in terms of variations in concentration and emissions levels of $\mathrm{PM}_{2.5}$ and $\mathrm{PM}_{10}$. This data is presented in a table and two graphs that can be filtered. The spreadsheet also provides a second part with detailed results, showing total emissions and concentration levels by type of technology for both the current and projected fleets. This second part provides six tables and four graphs that can be filtered.

In order to present the interface of the Environmental Stage, we have broken the spreadsheet into Figure A4, which presents the section with the main environmental results, and Figure A5, which presents the section with the detailed environmental results.

\section{ENVIRONMENTAL STAGE}

Instructions: This section analyzes the environmental results in terms of variation on the concentration and emissions levels of $\mathrm{PM}_{25}$ and $\mathrm{PM}_{10}$. This data is presented in tables and graphs that can be filtered. If you have provided input information in the "Additional Step" section of the previous sheet, go directly to the Epidemiological Stage sheet (next spreadsheet). If the levels of $\mathrm{PM}_{2.5}$ and $\mathrm{PM}_{10}$ emissions or concentration decrease (increase) as a result of the differences between the current and the projected fleet, all results will be given as negative (positive), meaning a reduction (growth) in emissions and concentration levels, epidemiological cases, and financial and economic costs.

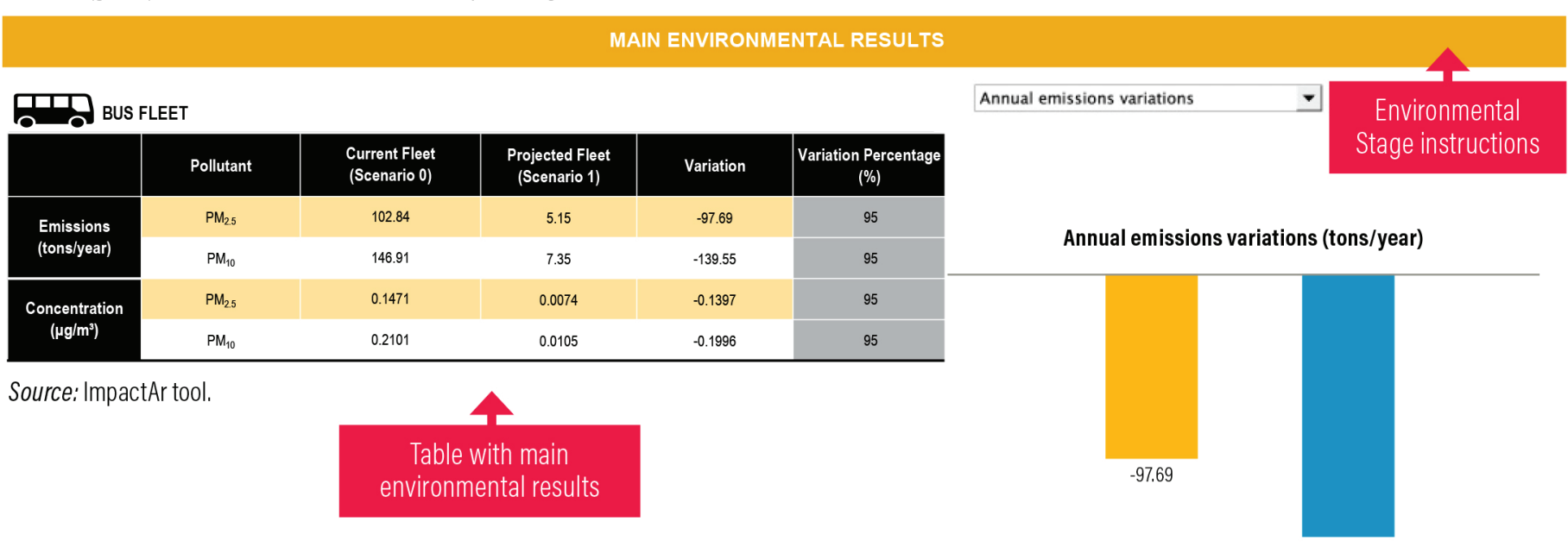




\begin{tabular}{|c|c|c|}
\hline \multicolumn{3}{|c|}{ CURRENT FLEET/SCENARIO 0 EMISSIONS } \\
\hline Type of bus & $\begin{array}{c}\text { Annual emissions of } \\
\text { particulate matter 2.5 } \\
\text { (tons/year) }\end{array}$ & $\begin{array}{c}\text { Annual emissions of } \\
\text { particulate matter 10 } \\
\text { (tons/year) }\end{array}$ \\
\hline Bus 1 & 84.29 & 120.42 \\
\hline Bus 2 & 18.55 & 26.49 \\
\hline Bus 3 & 0.00 & 0.00 \\
\hline Bus 4 & N/A & N/A \\
\hline Bus 5 & N/A & N/A \\
\hline Total & 102.84 & 146.91 \\
\hline
\end{tabular}

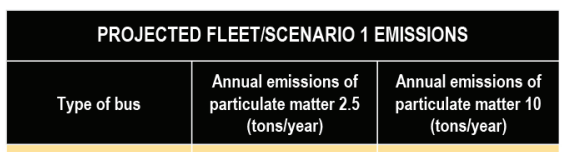

\begin{tabular}{|c|c|c|}
\hline Bus 1 & 3.59 & 5.13 \\
\hline Bus 2 & 1.55 & 2.22 \\
\hline Bus 3 & 0.00 & 0.00 \\
\hline Bus 4 & 0.00 & 0.00 \\
\hline Bus 5 & N/A & N/A \\
\hline Total & 5.15 & 7.35 \\
\hline
\end{tabular}
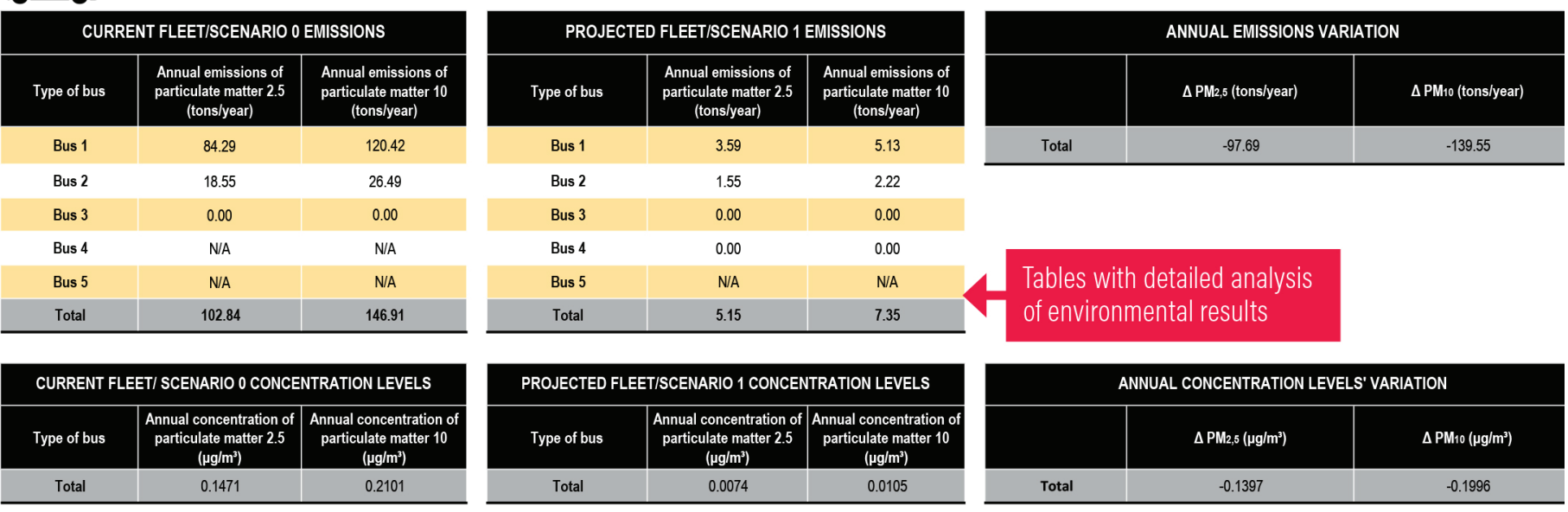

Current fleet concentration

Current fleet concentration - Scenario $0\left(\mu \mathrm{g} / \mathrm{m}^{3}\right)$

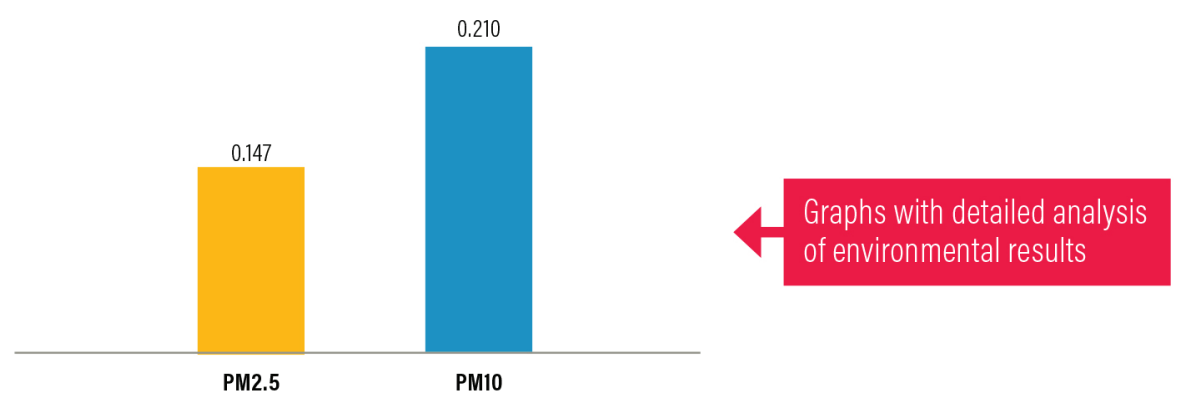

Source: ImpactAr tool.

Analysis of the epidemiological results spreadsheet (3_

EPIDEMIOLOGICAL_STAGE). In the first part of this section, the user can analyze the main epidemiological results as a function of variations in $\mathrm{PM}_{2.5}$ and $\mathrm{PM}_{10}$ concentration levels. These results are separated by fatal and nonfatal cases of respiratory disease and cardiovascular disease, and by 1-year and 30-year analyses. This data is presented in a table and 4 graphs that can be filtered. The worksheet also provides a second part with detailed results, presenting the above epidemiological findings by age group and type of financial coverage of cases (public or private). This part also includes two tables with the total numbers of workdays lost due to hospitalizations and the total number of workdays lost per age range.
We have not provided a table of work absences per type of financial coverage because we assumed the average stay to be the same for public and private hospitalizations. This part provides four tables and 14 graphs that can be filtered.

In order to present the interface of the Epidemiological Stage, we have broken the spreadsheet into Figure A6, which presents with the main epidemiological results; Figure $A 7$, which shows the first part of the detailed epidemiological results sections; Figure A8, which presents the second part; and Figure A9, which shows the third and final part of the detailed epidemiological results section. 
Figure A6 | Interface of the Epidemiological Stage Spreadsheet: Main Epidemiological Results-3_EPIDEMIIOLOGICAL_STAGE

Epidemiological
Stage instructions

Instructions: This section analyzes the epidemiological results in terms of variation on the concentration and emissions levels of $\mathrm{PM}_{2.5}$ and $\mathrm{PM}_{10}$. This data is presented in tables and graphs that can be filtered. If the levels of $\mathrm{PM}_{2.5}$ and $\mathrm{PM}_{10}$ emissions or concentration decrease (increase) as a result of the differences between the current and the projected fleet, all results will be given as negative (positive), meaning a reduction (growth) in emission and concentration levels, epidemiological cases, and financial and economic costs. All the results will be given as negative if the user provided input information in the "Additional Step" section of the "1_PROJECT" and concentration levels, epidemiological cases, and financial and economic costs. All the results will be given as negative if the user provided input information in the "Additional
spreadsheet as the tool will assume that air pollution levels for scenario 1 represent the values inputted by the user, and the air pollution levels for scenario 0 will be equal to zero.

\section{MAIN EPIDEMIOLOGICAL RESULTS}

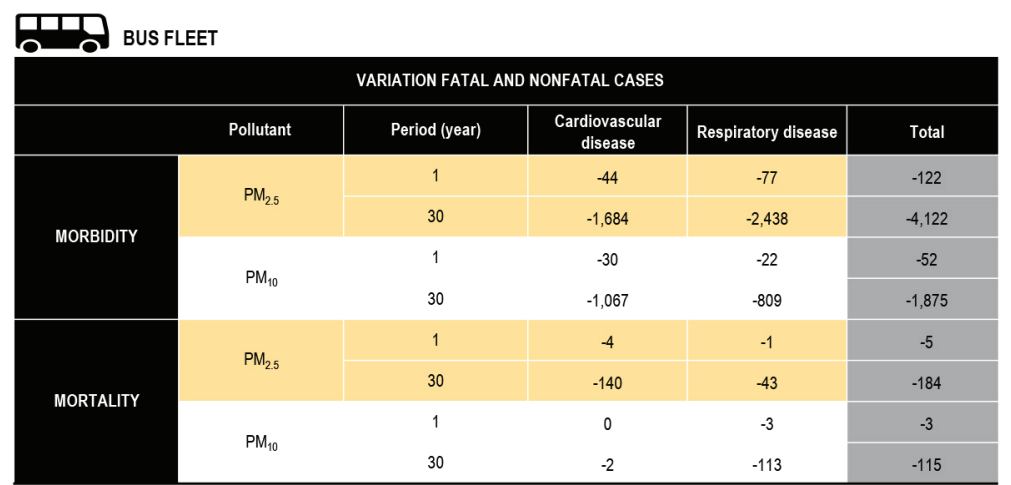

Source: ImpactAr tool.

30

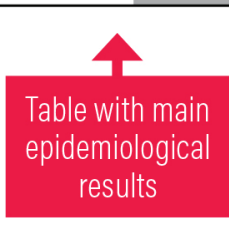

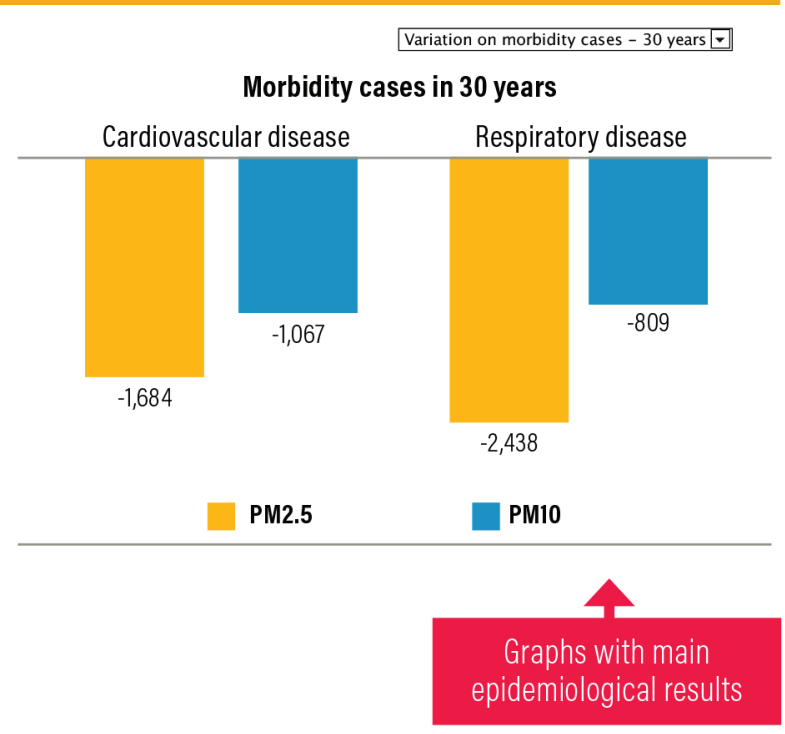

Figure A7 | Interface of the Epidemiological Stage Spreadsheet: First Part of the Detailed Epidemiological Results Section-3_EPIDEMIOLOGICAL_STAGE

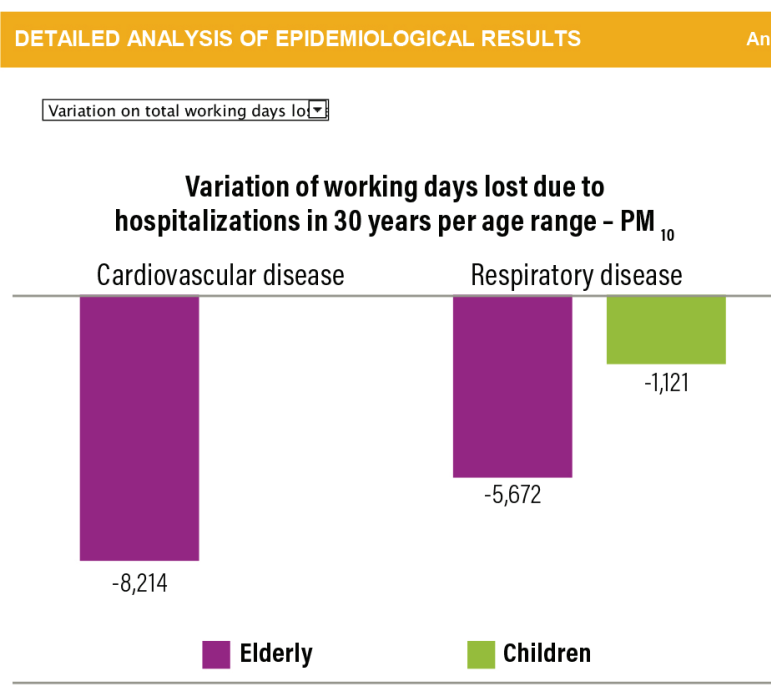

Source: ImpactAr tool. 
Figure A8 | Interface of the Epidemiological Stage Spreadsheet: Second Part of the Detailed Epidemiological Results Section-3_EPIDEMIOLOGICAL_STAGE

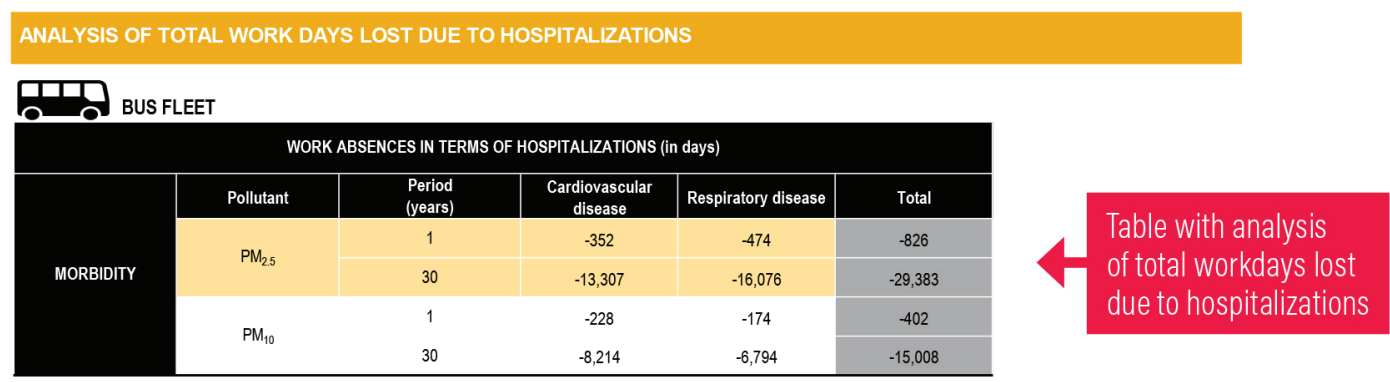

ANALYSIS OF TOTAL WORK DAYS LOST DUE TO HOSPITALIZATIONS PER AGE RANGE

\begin{tabular}{|c|c|c|c|c|c|c|}
\hline \multicolumn{7}{|c|}{ WORK ABSENCES IN TERMS OF HOSPITALZZATIONS (in days) } \\
\hline \multirow{9}{*}{ MORBIDTY } & Pollutant & Age range & $\begin{array}{l}\begin{array}{l}\text { Period } \\
\text { (vears) }\end{array} \\
\end{array}$ & $\begin{array}{c}\text { Cardiovascular } \\
\text { disease }\end{array}$ & Respiratory disease & Total \\
\hline & \multirow{4}{*}{$\mathrm{PM}_{25}$} & \multirow{2}{*}{ Elderly } & 1 & -352 & -195 & -547 \\
\hline & & & 30 & $-13,307$ & $-8,530$ & $-21,837$ \\
\hline & & \multirow{2}{*}{ Children } & 1 & N/A* & -279 & -279 \\
\hline & & & 30 & N/A* & $-7,547$ & $-7,547$ \\
\hline & \multirow{4}{*}{$\mathrm{PM}_{10}$} & \multirow{2}{*}{ Elderiy } & 1 & -228 & -130 & -358 \\
\hline & & & 30 & $-8,214$ & $-5,672$ & $-13,886$ \\
\hline & & \multirow{2}{*}{ Children } & 1 & $N / A^{*}$ & -45 & -45 \\
\hline & & & 30 & $\mathrm{~N} / \mathrm{A}^{*}$ & $-1,121$ & $-1,121$ \\
\hline
\end{tabular}

Table with analysis

4 of total workdays lost

due to hospitalizations

per age range

Source: ImpactAr tool.

Figure A9 | Interface of the Epidemiological Stage Spreadsheet: Third Part of the Detailed Epidemiological Results Section-3_EPIDEMIOLOGICAL_STAGE

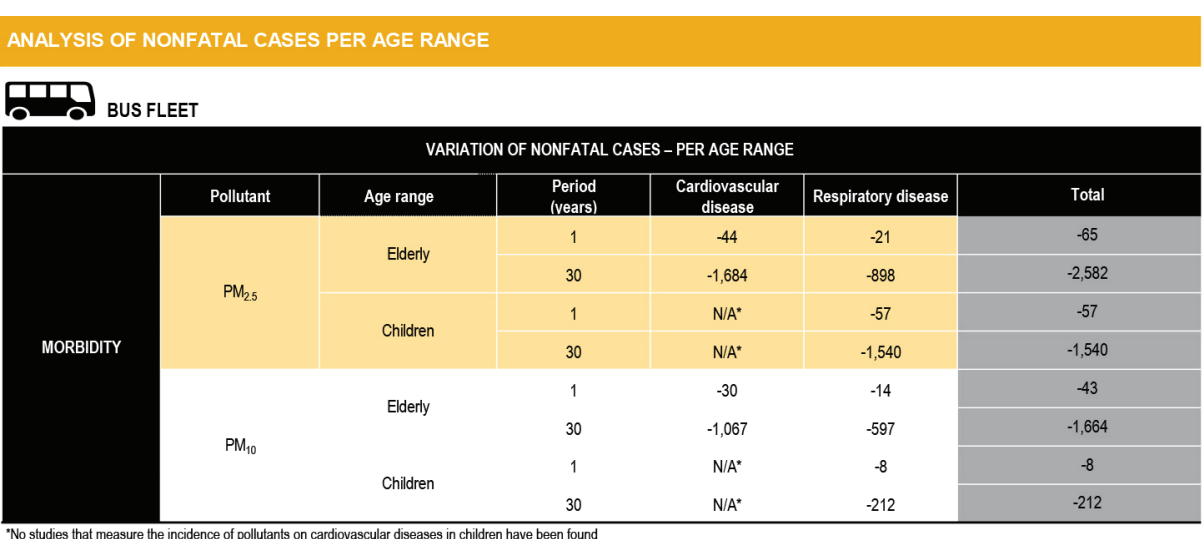

ANALYSIS OF NONFATAL CASES PER TYPE OF COVERAGE

\section{B.}

\begin{tabular}{|c|c|c|c|c|c|c|}
\hline \multirow{9}{*}{ MORBIITY } & Pollutant & $\begin{array}{l}\begin{array}{l}\text { Period } \\
\text { (years) }\end{array} \\
\end{array}$ & Coverage & $\begin{array}{c}\text { Cardiovascular } \\
\text { disease }\end{array}$ & Respiratory disease & Total \\
\hline & \multirow{4}{*}{$\mathrm{PM}_{25}$} & 1 & \multirow{2}{*}{ Public } & -19 & -39 & -58 \\
\hline & & 30 & & -702 & $-1,187$ & $-1,889$ \\
\hline & & 1 & \multirow{2}{*}{ Privale } & -26 & -38 & -64 \\
\hline & & 30 & & -982 & $-1,251$ & $-2,233$ \\
\hline & \multirow{4}{*}{$\mathrm{PM}_{10}$} & 1 & \multirow{2}{*}{ Public } & -12 & -9 & -21 \\
\hline & & 30 & & -445 & -313 & -758 \\
\hline & & 1 & \multirow{2}{*}{ Pivate } & -17 & -13 & -30 \\
\hline & & 30 & & -622 & -496 & $-1,118$ \\
\hline
\end{tabular}

There is no data for the separation of public and private fatal cases avoided

Source: ImpactAr tool.
Table with the

analysis of nonfatal

cases per age range 
Analysis of the financial and economic results spreadsheet

(4_FINANCE AND ECONOMIC_STAGE). In the first part of this section, the user can analyze the main financial and economic results according to the cases of mortality and morbidity linked to variations in $\mathrm{PM}_{2.5}$ and $\mathrm{PM}_{10}$ concentration levels. These results are separated by fatal and nonfatal cases of respiratory and cardiovascular diseases, and by 1-year and 30-year analyses. This data is presented in two tables and four graphs that can be filtered. The spreadsheet also provides a second part with the detailed results of morbidity-related costs. These costs are separated into the total cost of morbidity, the direct cost of morbidity (cost of hospitalization), and the indirect cost of morbidity (cost of income loss due to absences at work caused by hospitalization). The analyses are made by age group and by type of financial coverage of the cases (public or private). This part provides 6 tables and 24 graphs that can be filtered.
We have not provided the analysis of the mortality costs by age group because one of the $\mathrm{C}$-Rs for mortality does not offer this differentiation. Furthermore, we also have not included the analysis of the financial coverage of the mortality cases because the methodology used to measure the mortality costs (VSL) does not allow such classification (for further information, please see Section 2.1, Key Concepts)

In order to present the interface of the Financial and Economic Stage, we have broken the spreadsheet into Figure A10, which presents the main financial and economic results; Figure A11, which shows the first part of the detailed financial and economic results sections; Figure A12, which presents the second part of the detailed financial and economic results section; Figure $A 13$, which presents the third part of the detailed financial and economic results section; and A14, which presents the fourth and final part of the detailed financial and economic results section.

Figure A10 | Interface of the Financial and Economic Stage Spreadsheet: Main Financial and Economic Results-4_ FINANCIAL AND ECONOMIC_STAGE

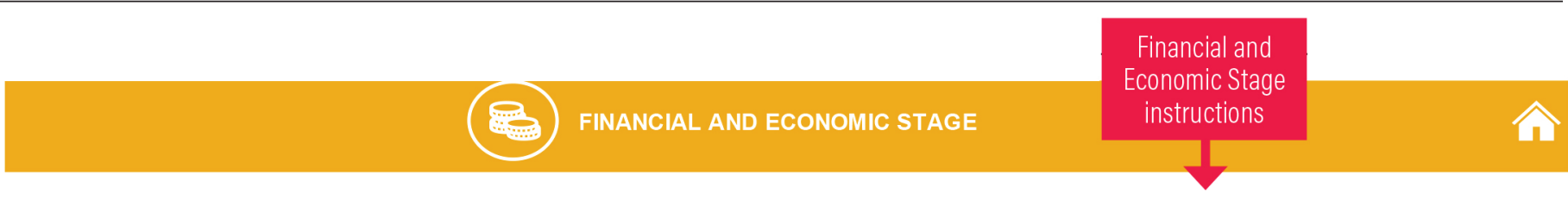

Instructions: This section analyzes the financial (morbidity costs) and economic (mortality costs) results in terms of variation on the concentration and emissions levels of $\mathrm{PM}_{25}$ and $\mathrm{PM}_{10}$. This data is presented in tables and graphs that can be filtered. If the levels of $\mathrm{PM}_{2.5}$ and $\mathrm{PM}_{10}$ emissions or concentration decrease (increase) as a result of the differences between the current and the projected fleet, all results will be given as negative (positive), meaning a reduction (growth) in emissions and concentration levels, epidemiological cases, and financial and economic costs. All the results will be given as negative if the user provided input information in the "Additional Step" section of the "1_PROJECT" spreadsheet as the tool will assume that air pollution levels for scenario 1 represent the values inputted by the user, and the air pollution levels for scenario 0 will be equal to zero.

\section{MAIN FINANCIAL AND ECONOMIC RESULTS}

\begin{tabular}{|c|c|c|c|c|c|}
\hline & & TOTAL & OF MORBIDITY C & & \\
\hline \multirow{5}{*}{ MORBIDITY } & Pollutant & $\begin{array}{l}\begin{array}{l}\text { Period } \\
\text { (years) }\end{array} \\
\end{array}$ & $\begin{array}{c}\text { Cardiovascular } \\
\text { disease (RS) }\end{array}$ & $\begin{array}{c}\text { Respiratory disease } \\
\text { (RS) }\end{array}$ & Total (RS) \\
\hline & \multirow{2}{*}{$\mathrm{PM}_{2.5}$} & 1 & $-241,559.33$ & $-161,895.78$ & $-403,455.11$ \\
\hline & & 30 & $-4,339,170.57$ & $-2,674,092.19$ & $-7,013,262.75$ \\
\hline & \multirow{2}{*}{$\mathrm{PM}_{10}$} & 1 & $-156,662.27$ & $-58,446.66$ & $-215,108.93$ \\
\hline & & 30 & $-2,718,564.27$ & $-1,053,785.87$ & $-3,772,350.13$ \\
\hline
\end{tabular}

\begin{tabular}{|c|c|c|c|c|c|}
\hline \multicolumn{6}{|c|}{ TOTAL MORTALITY COST } \\
\hline \multirow{5}{*}{ MORTALITY } & Pollutant & $\begin{array}{l}\begin{array}{l}\text { Period } \\
\text { (years) }\end{array} \\
\end{array}$ & $\begin{array}{l}\text { Cardiovascular } \\
\text { disease (RS) }\end{array}$ & $\begin{array}{c}\text { Respiratory disease } \\
\text { (RS) }\end{array}$ & Total (RS) \\
\hline & \multirow{2}{*}{$\mathrm{PM}_{2.5}$} & 1 & $-17,023,127.57$ & $-5,823,403.45$ & $-22,846,531.01$ \\
\hline & & 30 & $-296,653,715.16$ & $-94,584,168.20$ & $-391,237,883.36$ \\
\hline & \multirow{2}{*}{$\mathrm{PM}_{10}$} & 1 & $-207,966.44$ & $-11,662,607.92$ & $-11,870,574.35$ \\
\hline & & 30 & $-3,827,538.49$ & $-224,737,574.61$ & $-228,565,113.10$ \\
\hline
\end{tabular}

Source: ImpactAr tool.

\section{4}

Tables with the main financial and economic results

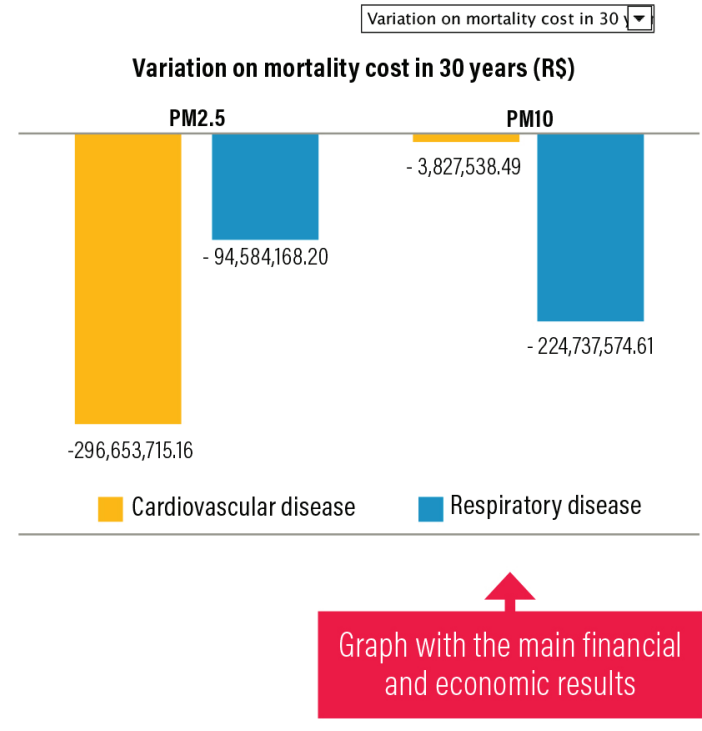


Figure A11 | Interface of the Financial and Economic Stage Spreadsheet: Part 1, Detailed Financial and Economic Results Section-4_FINANCIAL AND ECONOMIC_STAGE

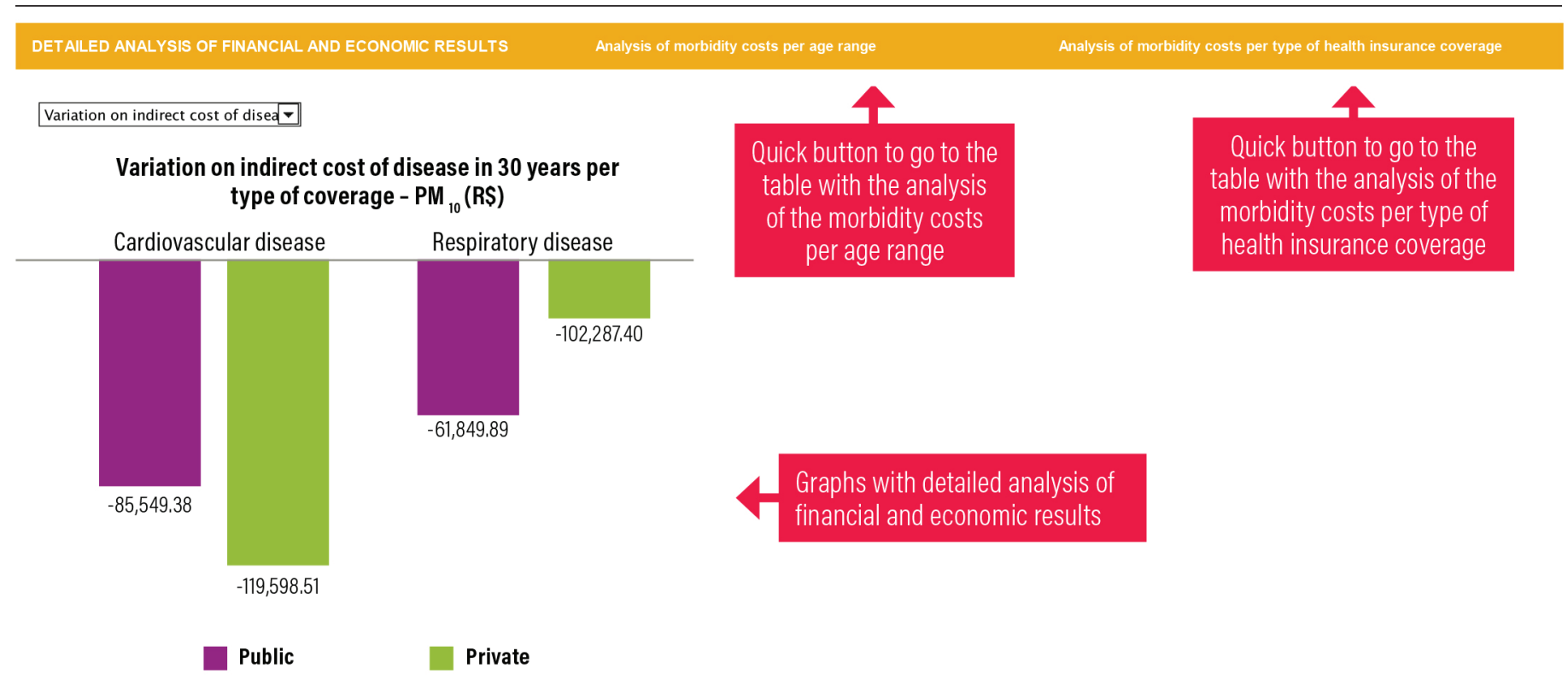

Source: ImpactAr tool.

Figure A12 | Interface of the Financial and Economic Stage Spreadsheet: Part 2, Detailed Financial and Economic Results Section, Tables with Total and Direct Costs of Morbidity per Age Range-4_FINANCIAL AND ECONOMIC_STAGE

\begin{tabular}{|c|c|c|c|c|c|c|}
\hline \multicolumn{7}{|c|}{ TOTAL MORBIDITY COSTS PER AGE RANGE } \\
\hline \multirow{9}{*}{ MORBIDITY } & Pollutant & Age range & $\begin{array}{l}\text { Period } \\
\text { (vears) }\end{array}$ & $\begin{array}{c}\text { Cardiovascular } \\
\text { disease (RS) }\end{array}$ & $\begin{array}{l}\text { Respiratory disease } \\
\text { (RS) }\end{array}$ & Total (R\$) \\
\hline & \multirow{4}{*}{$\mathrm{PM}_{25}$} & \multirow{2}{*}{ Elderly } & 1 & $-241,559.33$ & $-63,549.97$ & $-305,109.30$ \\
\hline & & & 30 & $-4,339,170.57$ & $-1,252,050.60$ & $-5,591,221.17$ \\
\hline & & \multirow{2}{*}{ Children } & 1 & $N / A^{*}$ & $-98,345.81$ & $-98,345.81$ \\
\hline & & & 30 & $N / A^{*}$ & $-1,422,041.59$ & $-1,422,041.59$ \\
\hline & \multirow{4}{*}{$\mathrm{PM}_{10}$} & \multirow{2}{*}{ Elderly } & 1 & $-156,662.27$ & $-42,261.18$ & $-198,923.45$ \\
\hline & & & 30 & $-2,718,564.27$ & $-832,622.43$ & $-3,551,186.70$ \\
\hline & & \multirow{2}{*}{ Children } & 1 & $N / A^{*}$ & $-16,185.48$ & $-16,185.48$ \\
\hline & & & 30 & $N / A^{*}$ & $-221,163.43$ & $-221,163.43$ \\
\hline
\end{tabular}
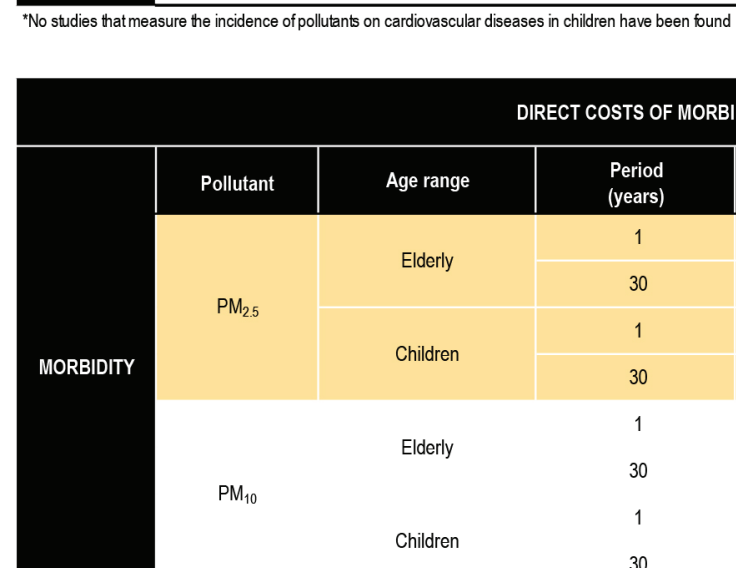
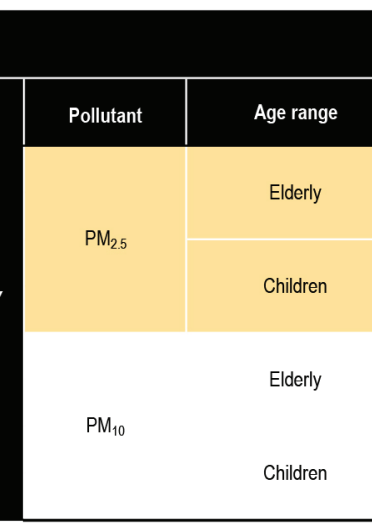

\section{DIRECT COSTS OF MORBIDITY PER AGE RANGE}

${ }^{*}$ No studies that measure the incidence of pollutants on cardiovascular diseases in children have been found

Age range

$\mathrm{M}_{25}$

$\mathrm{M}_{10}$

$\begin{array}{r}\hline \begin{array}{r}\text { Period } \\ \text { (year }\end{array} \\ \hline 1 \\ 30 \\ \hline 1 \\ \hline 30 \\ \hline 1\end{array}$

30
(20)

\begin{tabular}{|c|c|c|}
\hline $\begin{array}{c}\text { Cardiovascular } \\
\text { disease }(\mathbf{R} \$\end{array}$ & $\begin{array}{c}\text { Respiratory disease } \\
\mathbf{( R \$ )}\end{array}$ & $-53,429.04$ \\
\hline$-223,330.92$ & $-1,052,649.81$ \\
\hline$-4,011,730.57$ & $-83,875.94$ \\
\hline $\mathrm{N} / \mathrm{A}^{*}$ & $-1,212,813.02$ \\
\hline $\mathrm{N} / \mathrm{A}^{*}$ & $-35,530.69$ \\
\hline$-144,840.25$ & $-700,019.51$ \\
$-2,513,416.38$ & $-13,877.69$ \\
\hline $\mathrm{N} / \mathrm{A}^{*}$ & $-189,629.07$ \\
\hline $\mathrm{N} / \mathrm{A}^{*}$ & \\
\hline
\end{tabular}

Graphs with detailed analysis of

financial and economic results
Quick button to go to the table with the analysis of the morbidity costs per type of health insurance coverage

Source: ImpactAr tool. 
Figure A13 | Interface of the Financial and Economic Stage Spreadsheet: Part 3, Detailed Financial and Economic Results Section, Tables with Indirect Costs of Morbidity per Age Range and Total Costs of Morbidity per Type of Health Insurance Coverage-4_FINANCIAL AND ECONOMIC_STAGE

\begin{tabular}{|c|c|c|c|c|c|c|}
\hline \multicolumn{7}{|c|}{ INDIRECT COSTS OF MORBIDITY PER AGE RANGE } \\
\hline \multirow{9}{*}{ MORBIDITY } & Pollutant & Age range & $\begin{array}{l}\text { Period } \\
\text { (years) }\end{array}$ & $\begin{array}{l}\text { Cardiovascular } \\
\text { disease (R\$) }\end{array}$ & $\begin{array}{l}\text { Respiratory disease } \\
(\mathbf{R} \$)\end{array}$ & Total (RS) \\
\hline & \multirow{4}{*}{$\mathrm{PM}_{25}$} & \multirow{2}{*}{ Elderly } & 1 & $-18,228.41$ & $-10,120.93$ & $-28,349.34$ \\
\hline & & & 30 & $-327,440.00$ & $-199,400.79$ & $-526,840.79$ \\
\hline & & \multirow{2}{*}{ Children } & 1 & $N / A^{*}$ & $-14,469.87$ & $-14,469.87$ \\
\hline & & & 30 & $N / A^{*}$ & $-209,228.56$ & $-209,228.56$ \\
\hline & \multirow{4}{*}{$\mathrm{PM}_{10}$} & \multirow[b]{2}{*}{ Elderly } & 1 & $-11,822.02$ & $-6,730.49$ & $-18,552.51$ \\
\hline & & & 30 & $-205,147.88$ & $-132,602.93$ & $-337,750.81$ \\
\hline & & \multirow{2}{*}{ Children } & 1 & $N / A^{*}$ & $-2,307.79$ & $-2,307.79$ \\
\hline & & & 30 & $N / A^{*}$ & $-31,534.36$ & $-31,534.36$ \\
\hline
\end{tabular}

Table with detailed

analysis of the

indirect morbidity

costs per age range

\section{ANALYSIS OF MORBIDITY COSTS PER TYPE OF HEALTH INSURANCE COVERAGE:}

The average stay of public and piviate hospitalazaions were assumed to be the same. Therefore, the working dey loss as we.

\begin{tabular}{|c|c|c|c|c|c|c|}
\hline \multicolumn{7}{|c|}{ TOTAL MORBDITY COSTS PER TYPE OF COVERAGE } \\
\hline \multirow{9}{*}{ MORBIITY } & Pollutant & $\begin{array}{l}\text { Period } \\
\text { (years) }\end{array}$ & Coverage & $\begin{array}{l}\text { Cardiovascular } \\
\text { disease (RS) }\end{array}$ & $\begin{array}{l}\text { Respiratory disease } \\
(\mathbb{R S})\end{array}$ & Total $(R \&)$ \\
\hline & \multirow{4}{*}{$\mathrm{PM}_{25}$} & 1 & \multirow{2}{*}{ Public } & $-50,599.22$ & $-45,330.51$ & $\begin{array}{l}-95,929.73 \\
-\end{array}$ \\
\hline & & 30 & & $-908,922.18$ & $-716,445.85$ & $-1,625,368.04$ \\
\hline & & 1 & \multirow{2}{*}{ Private } & $-190,960.11$ & -116.565 .27 & $-307,525.38$ \\
\hline & & 30 & & $-3,430,248.38$ & $-1,957,646.34$ & $-5,387,894.72$ \\
\hline & \multirow{4}{*}{$\mathrm{PM}_{10}$} & 1 & \multirow{2}{*}{ Public } & $-32,815.92$ & -12,279.86 & $-45,095.78$ \\
\hline & & 30 & & $-569,455.49$ & $-214,503.63$ & $-783,959.12$ \\
\hline & & 1 & \multirow{2}{*}{ Private } & $-123,846.35$ & $-46,166.79$ & $-170,013.15$ \\
\hline & & 30 & & $-2149,10878$ & $-839,282.23$ & $-2,988,391.01$ \\
\hline
\end{tabular}

Table with detailed

analysis of the total

morbidity costs per type of

health insurance coverage

Source: ImpactAr tool.

Figure A14 | Interface of the Financial and Economic Stage Spreadsheet: Part 4, Detailed Financial and Economic Results Section, Tables with Direct and Indirect Costs of Morbidity per Type of Health Insurance Coverage-4_FINANCIALAND ECONOMIC_STAGE
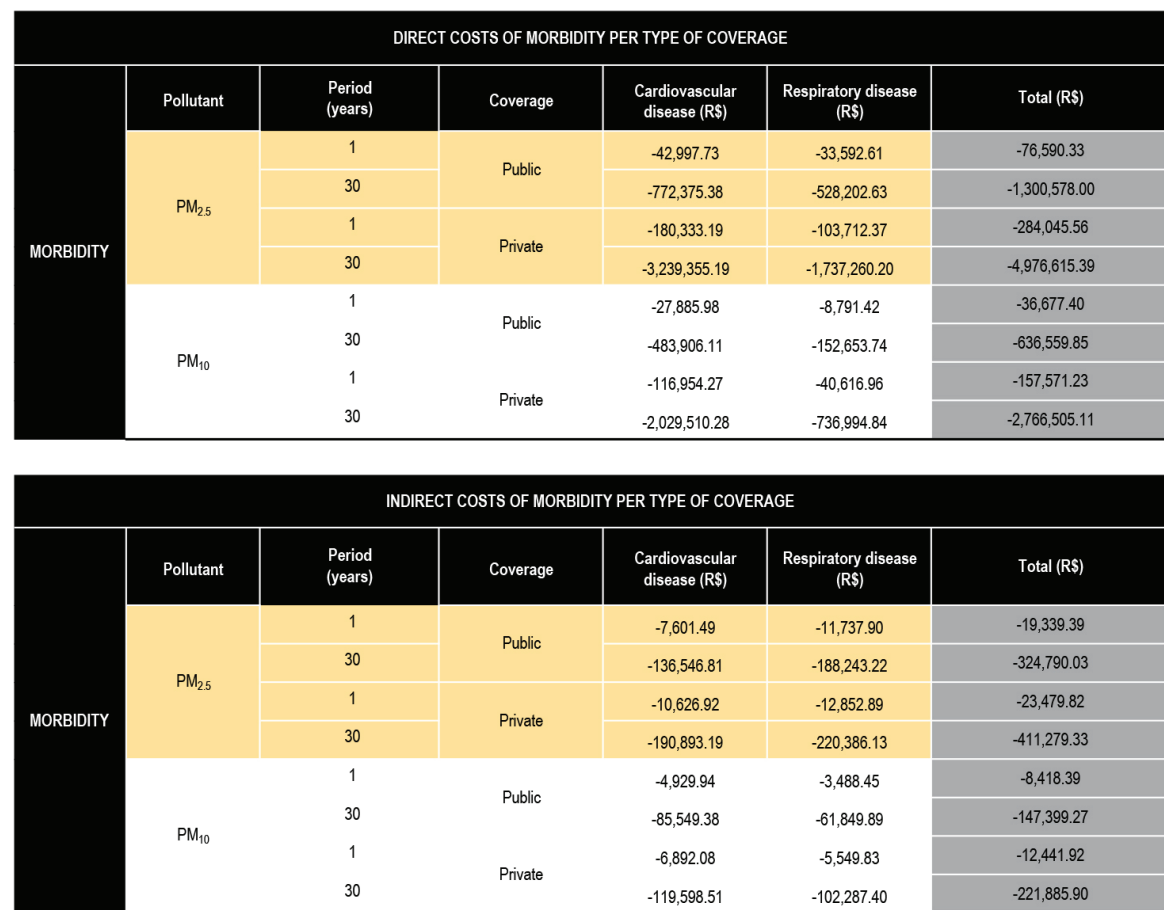

INDIRECT COSTS OF MORBIDITY PER TYPE OF COVERAGE

\begin{tabular}{|c|c|c|c|}
\hline Coverage & $\begin{array}{c}\text { Cardiovascular } \\
\text { disease (RS) }\end{array}$ & $\begin{array}{c}\text { Respiratory disease } \\
\mathbf{( R S )}\end{array}$ & Total (R\$) \\
\hline \multirow{2}{*}{ Public } & $-7,601.49$ & $-11,737.90$ & $-19,339.39$ \\
\hline \multirow{2}{*}{ Private } & $-136,546.81$ & $-188,243.22$ & $-324,790.03$ \\
\hline \multirow{2}{*}{ Public } & $-10,626.92$ & $-12,852.89$ & $-23,479.82$ \\
\hline & $-190,893.19$ & $-220,386.13$ & $-411,279.33$ \\
\hline \multirow{2}{*}{ Private } & $-4,929.94$ & $-3,488.45$ & $-8,418.39$ \\
\hline & $-85,549.38$ & $-61,849.89$ & $-147,399.27$ \\
\hline & $-6,892.08$ & $-5,549.83$ & $-12,441.92$ \\
\hline
\end{tabular}

Source: ImpactAr tool.
Table with detailed

analysis of the direct

morbidity costs per type of

health insurance coverage
Table with detailed

analysis of the indirect

morbidity costs per type of

health insurance coverage 
Analysis of the main results spreadsheet (5_MAIN RESULTS). In the first part of this section, a table is provided with the main environmental, epidemiological, financial, and economic results of the simulation for the 1-year and 30-year periods. After it, in the second part, the spreadsheet presents a table with a comparative analysis between the financial and economic results for the 1-year and 30-year periods and the municipal GDP, the 2018 annual municipal health expenditure, the 2018 annual municipal hospitalization expenditure, and the number of medical appointments "saved" or "spent" as a function of the financial savings/ losses caused by the bus fleet change or by the environmental input data.

In order to present the interface of the Main Results, we have broken the spreadsheet into Figure A15, which presents the first section of the spreadsheet, and Figure A16, which presents the second and final section of the spreadsheet.

Figure A15 | Interface of the Main Results Spreadsheet: Sheet 5, Section 1

\section{(4ili) man susurs}

Instructions: This section provides the main results - environmental, epidemiological, and economic-financial - that the changes in $\mathrm{PM}_{10}$ and $\mathrm{PM}_{25}$ annual concentration levels originated by the fleet's renewal or by the direct air quality inputs of the user would produce. It also offers a comparative analysis between economic and financial results and economic indicators of the municipality, such as the municipal GDP, municipal annual health expenditure, and average cost of hospitalizations in the municipality. Values are provided for 1 year (short-run analysis) and 30 years (long-run analysis). If the levels of $\mathrm{PM}_{25}$ and $\mathrm{PM}_{10}$ emissions or concentration decrease (increase) as a result of the differences between the current and the projected fleet, all results will be given as negative (positive), meaning a reduction (growth) in emission and concentration levels, epidemiological cases, and financial and economic costs. All the results will be given as negative if the user provided input information in the "Additional Step" section of the "1_PROJECT" spreadsheet as the tool will assume that air pollution levels for scenario 1 represent the values inputted by the user, and the air pollution levels for scenario 0 will be equal to zero.

MAIN SIMULATION'S RESULT

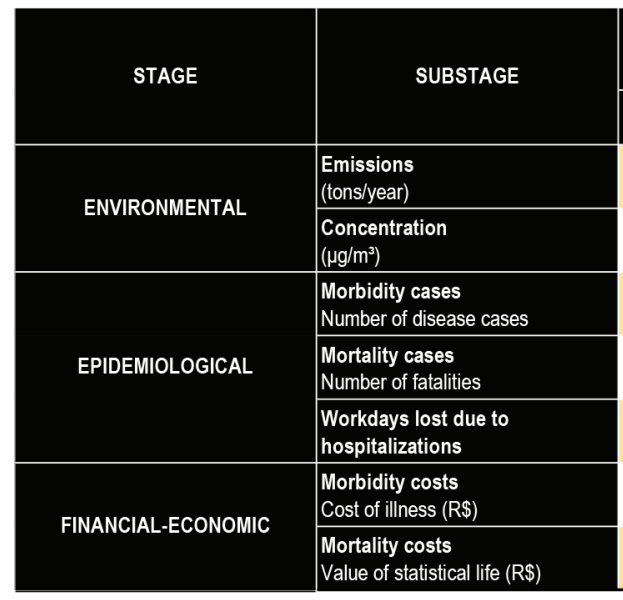

Source: ImpactAr tool.

\begin{tabular}{|c|c|c|c|}
\hline \multicolumn{2}{|c|}{$\mathrm{PM}_{25}$} & \multicolumn{2}{|c|}{$\mathrm{PM}_{10}$} \\
\hline 1 year & 30 years & 1 year & 30 years \\
\hline \multicolumn{2}{|c|}{-97.69} & \multicolumn{2}{|c|}{-139.55} \\
\hline \multicolumn{2}{|c|}{-0.1397} & \multicolumn{2}{|c|}{-0.1996} \\
\hline-122 & $-4,122$ & -52 & $-1,875$ \\
\hline-5 & -184 & -3 & -115 \\
\hline-826 & $-29,383$ & -402 & $-15,008$ \\
\hline$-403,455.11$ & $-7,013,262.75$ & $-215,108.93$ & $-3,772,350.13$ \\
\hline$-22,846,531.01$ & $-391,237,883.36$ & $-11,870,574.35$ & $-228,565,113.10$ \\
\hline
\end{tabular}

Table with the main results of the simulation

Figure A16 | Interface of the Main Results Spreadsheet: Sheet 5, Section 2

\begin{tabular}{|c|c|c|c|c|c|c|c|c|c|c|c|}
\hline \multirow{2}{*}{ Period } & \multirow{2}{*}{ Substage } & \multicolumn{2}{|c|}{ Total Costs Varietion (RS) } & \multicolumn{2}{|c|}{ Total Costs Varation'CDPm (\%) } & \multicolumn{2}{|c|}{$\begin{array}{l}\text { Total Costs Variation/Annual Health } \\
\text { Expenditure ( } \%)\end{array}$} & \multicolumn{2}{|c|}{$\begin{array}{l}\text { Total Costs Variation/Annual Hospital } \\
\text { Expendilure (\%) }\end{array}$} & \multicolumn{2}{|c|}{$\begin{array}{l}\text { Number of Hospitilizations due to } \\
\text { Savings/C Costs of the Fleet Changes (\%) }\end{array}$} \\
\hline & & $\mathrm{PM}_{23}$ & $\mathrm{PM}_{\mathrm{w}}$ & $\mathrm{PM}_{23}$ & $\mathrm{PM}_{\mathrm{v}_{\mathrm{v}}}$ & $\mathrm{PM}_{23}$ & $\mathrm{PM}_{1 \mathrm{v}}$ & $\mathrm{PM}_{23}$ & $\mathrm{PM}_{\mathrm{in}}$ & $\mathrm{PM}_{2 \mathrm{I}}$ & $\mathrm{PM}_{\mathrm{v}_{\mathrm{v}}}$ \\
\hline \multirow{2}{*}{1 year } & Morbidity & $403,455.11$ & $-215,108.93$ & 0.00031222 & 0.0001665 & 0.00400564 & 0.00217833 & 0.04827074 & 0.02573636 & 145 & $\pi$ \\
\hline & Mortality & $-22,846,531.01$ & $-11,870,574.35$ & 0.01768015 & 0.0091862 & $\therefore$ &. & $\therefore$ & $\therefore$ & $\therefore$ & $\therefore$ \\
\hline \multirow{2}{*}{30 years } & Morbidity & -7.013 .26275 & -3.772 .350 .13 & 0.0054273 & 0.0029193 & 0.07102072 & 0.03320120 & 0.8398052 & 0.45133675 & 2526 & 1359 \\
\hline & Mortality & -391.237 .883 .36 & -228.565 .113 .10 & 0.30276556 & 0.1768787 & -* & $\therefore$ & . &. & $\therefore$ & . \\
\hline
\end{tabular}

GOPM - municipal gross domesic product

Source: ImpactAr tool. 
The long-term analysis spreadsheet (6_LONG-RUN ANALYSIS).

In this spreadsheet, the user can filter eight types of graphs with information regarding the evolution of morbidity and mortality cases per year as well as the associated costs per year. Charts provide quantitative values every five years (Figure A16).

Instructions: This section provides graphics with the annual morbidity and mortality cases and their respective costs over 30 years, with data provided every 5 years. If the $\mathrm{PM}_{2.5}$ and $\mathrm{PM}_{10}$ emissions and concentration levels decrease (increase) as a result of the differences between the current and the projected fleet, all results will be given as negative (positive), meaning a reduction (growth) in emissions and concentration levels, epidemiological cases, and financial and economic costs. All the results will be given as negative if the user provided input information in the "Additional Step" section of the "1_PROJECT" spreadsheet as the tool will assume that air pollution levels for scenario 1 represent the values inputted by the user, and the air pollution levels for scenario 0 will be equal to zero.

\section{MAIN LONG-RUN ANALYSIS RESULTS}

Cumulative variation of total morbidity cases - respirato -1

Cumulative variation of total morbidity cases - respiratory disease

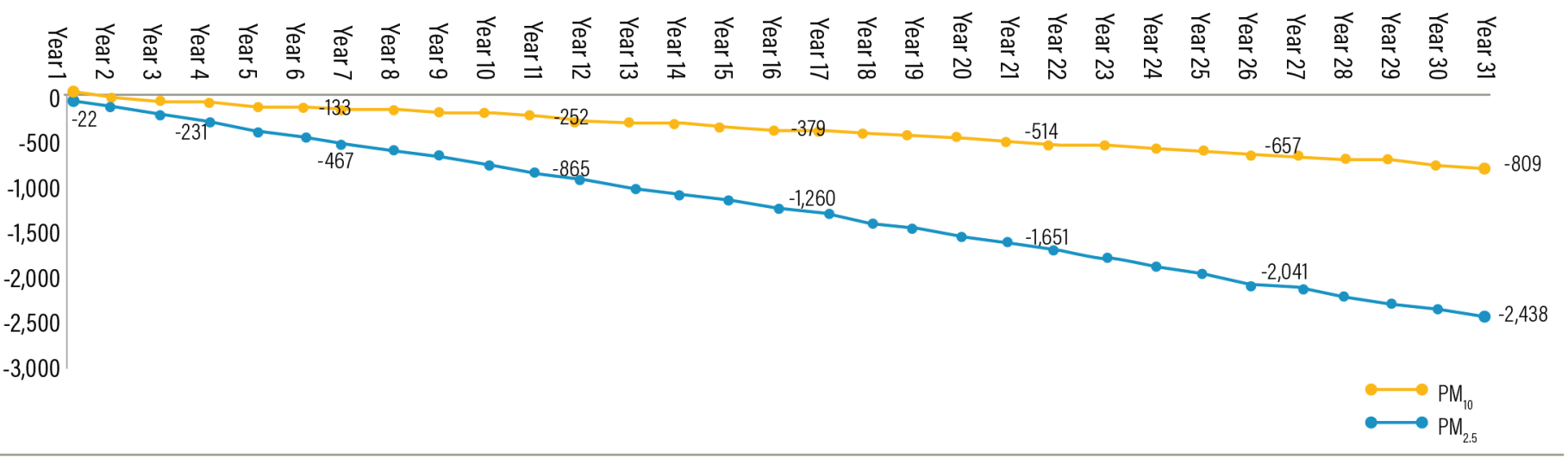

Source: ImpactAr tool. 


\section{APPENDIX B. BRAZILIAN LITERATURE REVIEW ON HEALTH AND ECONOMIC IMPACTS OF AIR POLLUTION- METHODOLOGY DESCRIPTION, MAIN FINDINGS, AND CONTRIBUTIONS TO BUILD THE IMPACTAR TOOL}

The methodologies and data applied to build the ImpactAr tool was based on the most recent and well-grounded Brazilian empirical literature on the measurement of air pollution impacts on health and economy in the country. During the first stages of the ImpactAr tool project, WRI Brasil carried out a survey on the state-of-the-art studies that analyzed air pollution impacts in Brazilian cities to understand how the impacts linked to pollutants are manifested and measured in the Brazilian context. To that end, a literature review was conducted with the following research question: What are the economic and health impacts of urban air pollution in Brazil?

The review was stratified in a three-stage process (Table B1). In Stage 1, the WRI team carried out searches on the main academic search platforms with predefined keywords. Stage 2 consisted of researching publications from the key researchers and institutions identified in Stage 1. Finally, in Stage 3, the WRI team held a workshop with the key

\section{Table B1 | Description of the Literature Review Stages}

\section{STAGE 1 | KEYWORDS ON ACADEMIC SEARCH PLATFORMS}

- Platforms: Scielo, Google Scholar, Capes, and Science Direct

- Keywords: air quality, economic impacts, brazil, urban air pollution, impacts, valuation, urban, air pollution, urban, monuments, restoration, leisure

- Around 1.200 studies analyzed

- $\quad$ Number of studies retrieved: 52

\section{STAGE 2 | SEARCH OF KEY ACTOR PUBLICATIONS}

- Names found on actors mapping (platform search)

- $\quad$ Number of studies retrieved: 9

\section{STAGE 3 | SPECIALIST SUGGESTIONS FROM WORKSHOP AND} INSTITUTE PLATFORMS

- Workshop took place on the June 22, 2018

- Platforms of institutes searched: Institute of Health and Sustainability (Instituto Saúde e Sustentabilidade, ISS); Institute for Energy and Environment (Instituto Energia e Meio Ambiente, IEMA)

- $\quad$ Number of studies retrieved: 6 researchers and institutions for validation of the literature review. This process was carried out over a period of approximately six months and mapped 67 studies from which the main choices of health impacts and methodologies applied in the ImpactAr tool were retrieved.

Among the main features within these 67 studies, we were able to identify that the most commonly researched pollutant was $\mathrm{PM}_{10}$, followed by ozone (03), but $\mathrm{PM}_{2.5}$ was studied less frequently. Furthermore, we learned that, besides the fact that PM is strongly linked to bus emissions and is also considered the most harmful pollutant (WHO 2018), $\mathrm{PM}_{10}$ and $\mathrm{PM}_{2.5}$ present different emissions sources from road transport activities (Hooftman et. al 2016) and different health impact incidence (Abe and Miraglia 2016; Silva et al. 2017). In this sense, although it is not possible to total the impacts of $\mathrm{PM}_{10}$ and $\mathrm{PM}_{2.51}$ as $\mathrm{PM}_{10}$ particles circumscribe $\mathrm{PM}_{2.5}$ particles, the WRI team has opted to include both pollutants in the scope of the ImpactAr tool.

In relation to the analysis of the studied health endpoints in the publications, a significant predominance of fatal respiratory (41.8 percent), fatal cardiovascular (28.3 percent), nonfatal respiratory (50.7 percent), and nonfatal cardiovascular (32.8 percent) diseases was verified. Therefore, the WRI team included these health impacts in the ImpactAr tool analysis and retrieved the C-Rs used to measure the epidemiological impacts from 7 articles among the 67 publications.

Finally, regarding the financial and economic aspects addressed in the publications, a minor share of the studies, 22 out 67 (33 percent), monetized the health impacts of air pollution. Amid the main methodologies, we can list the COI to measure financial impacts of hospitalizations, which was added to this tool. In relation to the monetization of deaths, the WRI team opted to use the VSL method, which was presented in some publications. The literature did not present recent primary data on the VSL, nor did it provide a standard value for Brazil. Therefore, to obtain the VSL, we have transferred the reference value provided by the 2012 OECD study with adjustment to income and inflation (Roy and Braathen 2017). 


\section{ABBREVIATIONS}

ANS Agência Nacional de Saúde Suplementar (National Agency for Supplementary Health)

BRAMS Brazilian Developments on the Regional Atmospheric Modeling System

BRIICS Brazil, Russia, Indonesia, India, China and South Africa

CCATT Coupled Chemistry Aerosol-Tracer Transport

CIFF Children's Investment Fund Foundation

COI cost of illness

$\mathrm{CO}_{2} \quad$ carbon dioxide

CPTEC Centro de Previsão do Tempo e Estudos Climáticos (Center for Weather Forecast and Climatic Studies)

C-R concentration-response coefficient

DALY disability-adjusted life years

DATASUS Departamento de Informática do Sistema Único de Saúde (Brazilian Health Informatics Department)

EPA U.S. Environmental Protection Agency

ExternE external costs of energy

FCM fixed conversion measure

GDP gross domestic product

GDPm municipal gross domestic product

GHG greenhouse gas

GIS Geographic Information System

GTFS General Transit Feed Specification

IBGE Instituto Brasileiro de Geografia e Estatística (Brazilian Institute of Geography and Statistics)

ICD-10 $10^{\text {th }}$ revision of the International Statistical Classification of Diseases and Related Health Problems

IEMA Instituto Energia e Meio Ambiente (Institute for Energy and the Environment)

ImpactAr valuation tool for health impacts of air pollution

INPE Instituto Nacional de Pesquisas Espaciais (National Institute for Space Research)

IPA impact pathway approach

IPCA Índice Nacional de Preços ao Consumidor Amplo (Broad National Consumer Price Index)

IPCC Intergovernmental Panel on Climate Change

ISS Instituto Saúde e Sustentabilidade (Institute of Health and Sustainability)

NOx nitrogen oxides

OECD Organisation for Economic Co-operation and Development

\section{$\mathbf{0}_{3} \quad$ ozone}

PM particulate matter

RCP Representative Concentration Pathway

SIDRA Sistema IBGE de Recuperação Automática (IBGE Automatic Recovery System)

SLCF short-lived climate forcer

VSL value of statistical life

WRI World Resources Institute

WTP willingness to pay

\section{ENDNOTES}

1. Anthropogenic sources are caused by human activities.

2. In terms of PM share of transport emissions from exhaust and wear/ combustion, buses account for 17 percent and 14 percent, and trucks account for 75 percent and 64 percent, respectively (MMA 2014).

3. Information retrieved from literature review of the state-of-the-art Brazilian empirical studies on the issue of health and economic impacts of air pollution. For further information, please see Appendix B.

4. It is important to note that the ImpactAr tool does not aim to provide users with a benefit-cost analysis of projects to renew a bus fleet but rather to point to the existence and magnitude of the implicit costs of air pollution embedded in such plans.

5. To see the list of all data and variables used in the model, please see Section 4, Data Sources.

6. The BRAMS 5.2 modeling system is an online model with an Eulerian approach and basically solves the mass conservation equation for any tracer. It has an extensive network of collaborators in the world and has been developed and adjusted to the South American continent, which makes it an integrated environmental model tuned for tropical and extratropical areas. BRAMS also includes a surface scheme to simulate the energy, water, carbon, and other biogeochemical cycles (Moreira et al. 2013) and soil moisture initialization using real-time cycling estimation from an offline hydrological model (Gevaerd and Freitas 2006). In Brazil, BRAMS has been applied for numerical studies in several universities and research centers addressing local storms, urban heat islands, urban and remote air pollution, aerosol-cloudradiation interactions, and so forth.

7. ExternE is the abbreviation for "external costs of energy." Between the 1990s and 2005, the European Union initiated a series of ExternE projects. The "ExternE Methodology" is an approach of calculating environmental external costs developed during the ExternE Project series called the IPA (ExternE, n.d.).

8. For further information, please see Appendix B.

9. Whereas $\mathrm{PM}_{2.5}$ emissions are linked to exhaust sources, such as fuel combustion, $\mathrm{PM}_{10}$ emissions are linked to both exhaust and nonexhaust sources such as fuel combustion, brakes, tires, and road surface wear (Hooftman et al. 2016, 7).

10. Although both types of pollutants are linked to respiratory and cardiovascular diseases, $\mathrm{PM}_{2.5}$ emissions present a greater risk for the development of cardiovascular diseases, and $\mathrm{PM}_{10}$ emissions are more strongly linked to respiratory diseases.

11. See the National Traffic Department (Departamento Nacional de Trânsito), https://www.denatran.gov.br/component/content/ article/115-portal-denatran/8558-frota-de-veiculos-2018.html.

12. Technology categories contemplated in the tool are Technology $1-$ Euro V, Technology 2-Euro III, Technology 3-Electric, Technology 4Hybrid, Technology 5-Trolleybus, Technology 6-Biodiesel B20 (20\% biodiesel), and Technology 7-Euro VI.

13. Emissions factors ( $\mathrm{g} P M / L$ diesel) and fuel efficiency ( $\mathrm{L}$ or $\mathrm{kWh} / 100$ $\mathrm{km}$ ) by default per technology are Euro V, 0.07 and 59.3; Euro III, 0.30 and 57; electric, 0 and 1.3; hybrid, 0.04 and 41.5; trolleybus, 0 and 2.29; biodiesel B20 (20\% biodiesel), 0.06 and 57; and Euro VI, 0.03 and 59.3. For further information on emissions factors and average fuel efficiency by default, please see Table 4, Data Sources Specifications.

14. The Handbook Emission Factors for Road Transport, version 3.3, is published as an online software program by the German Environment Agency (Berlin); the Federal Office for the Environment (Bern, Switzerland); the Environment Agency Austria (Vienna); the Austrian Federal Ministry of Agriculture, Forestry, Environment and Water Management (Vienna); and the Austrian Ministry of Transport, Innovation and Technology (Vienna); the Swedish Transport Administration (Borlänge); the French Environment \& Energy Management Agency (Angers); the Joint Research Centre of the 
European Commission (Ispra, Italy); and INFRAS (Bern, Switzerland). For more information, see https://www.hbefa.net.

15. For further information, please see linking function 2, from annual variations on emissions levels to annual variations on concentration levels, in this technical note.

16. The coefficient of determination obtained by the applied dispersion/ chemical transport models was about one for all four Brazilian cities. Even though this relation does not seem common for these metropolises, the model uses an Eulerian approach, solving the mass conservation equation for any tracer. The main aspect is the homogeneity of meteorological initial and boundary conditions for all scenarios and the existence of only emissions associated with the public transport in the chosen cities, with other emissions information not being used in the simulations. In addition, only primary PM dispersion was studied (transport, sedimentation, wet and dry deposition), without chemical transformations.

17. As we are unable to obtain the specific age of deaths and diseases (due to the predefined age ranges provided by the Department of Information Technology of the National Public Health System (Departamento de Informática do Sistema Único de Saúde, DATASUS), we preferred not to use the disability-adjusted life years (DALY) methodology.

18. For this tool, nonfatal and fatal diseases cover respiratory and cardiovascular events (Chapters I and I of the ICD-10, respectively) because these are the most studied impacts when it comes to air pollution among Brazilian empirical literature.

19. For further information on the total annual number of fatal and nonfatal diseases for each city's population, covered by the public health system and private health system, please see Box 1 .

20. It is important to note that morbidity costs can also be measured in terms of welfare losses, such as pain and suffering. We opted to use a financial measure, however, as we intended to compare such costs with the municipal health expenditure. For further discussion on the economic costs of air pollution morbidity impacts in Brazil, please see Ortiz et al. (2011).

21. For further discussion on national contingent valuation to assess the economic costs of air pollution mortality, please see Ortiz, Markandya, and Hunt (2009).

22. Revealed preference methods consist of the analysis of individual preferences based on the observation of individual behaviors in the market. In turn, stated preference methods consist of the analysis of individual preferences through interviews and questionnaires.

23. The Intergovernmental Panel on Climate Change (IPCC) projections for greenhouse gas (GHG) concentrations commonly used in regional climate models for impact projection.

24. For further discussion of the factors affecting the VSL, please see Alberini et al. (2016), OECD (2012), and Urvashi and Sall (2016).

25. The only epidemiological parameter obtained outside of the Brazilian context was retrieved from Fajersztajn et al. (2017).
26. Population data consist of an estimate of 2018 values and GDP data consist of an estimate of 2016 values (2018 prices), according to the IBGE.

27. For more information, see the National Traffic Department (Departamento Nacional de Trânsito), https://www.denatran.gov. br/component/content/article/115-portal-denatran/8558-frota-deveiculos-2018.html.

28. According to municipal law 16.802/2018, article 50, "From the date of publication of this Law, the operators of collective transportation services by bus, members of the Urban Passenger Transportation System of the Municipality of São Paulo, as well as the companies that render services for the collection of Urban and Hospital Solid Waste in the Municipality of São Paulo should promote the progressive reduction of emissions of carbon dioxide (CO2) of fossil origin and of toxic pollutants emitted in the operation of their respective fleets through the gradual use of cleaner and more sustainable fuels and technologies" (Prefeitura do Município de São Paulo 2018b, article 50).

29. After meeting with the city representative of the transit department, SPTrans, we learned that the city intended to increase the trolleybus fleet by 49 buses.

30. We note once more that $\mathrm{PM}_{2.5}$ and $\mathrm{PM}_{10}$ emissions and concentration variations and impacts cannot be summed because $\mathrm{PM}_{2.5}$ is contained in $\mathrm{PM}_{10}$.

31. According to the 2011 United Nations Environment Programme report, "Short-lived climate forcers (SLCFs): substances such as methane, black carbon, tropospheric ozone and many hydrofluorocarbons (HFCs) which have a significant impact on near-term climate change and a relatively short lifespan in the atmosphere compared to carbon dioxide and other longer-lived gases" (UNEP 2011, 7).

32. Please note that the size of the figures varied greatly in comparison with the actual size of the Excel sheet in order to make the information legible. Furthermore, the arrows in the figure are not in the tool and were added in the technical note to improve the understanding of the user. 


\section{REFERENCES}

Abe, K., and S. Miraglia. 2016. "Health Impact Assessment of Air Pollution in São Paulo, Brazil." International Journal of Environmental Research and Public Health 13 (7): 694. https://doi.org/10.3390/ijerph13070694.

Alberini, A., A. Bigano, J. Post, and E. Lanzi. 2016. "Approaches and Issues in Valuing the Costs of Inaction of Air Pollution on Human Health." OECD Environment Working Paper 108, OECD, Paris, https://doi. org/10.1787/5jlww02k83r0-en.

Alonso, M.F., K.M. Longo, S.R. Freitas, R.M. da Fonseca, V. Marécal, M. Pirre, and L.G. Klenner. 2010. "An Urban Emissions Inventory for South America and Its Application in Numerical Modeling of Atmospheric Chemical Composition at Local and Regional Scales." Atmospheric Environment 44 (39): 5072-83. https://doi.org/10.1016/j.atmosenv.2010.09.013

Amato-Lourenço, L.F., T.C.L. Moreira, V.C. de Oliveira Souza, F. Barbosa Jr., M. Saiki, P.H.N. Saldiva, and T. Mauad. 2016. "The Influence of Atmospheric Particles on the Elemental Content of Vegetables in Urban Gardens of Sao Paulo, Brazil." Environmental Pollution 216 (September): 125-34. https://doi. org/10.1016/j.envpol.2016.05.036.

André, P.A. de, M.M. Veras, S.G.E.K. Miraglia, and P.H.N. Saldiva. 2012. "Lean Diesel Technology and Human Health: A Case Study in Six Brazilian Metropolitan Regions." Clinics 67 (6): 639-46. https://doi.org/10.6061/ clinics/2012(06)15.

André, P.A. de, E. Vormittag, and P.H.N. Saldiva. 2017. Avaliação e valoração dos impactos da poluição do ar na saúde da população decorrente da substituição da matriz energética do transporte público na cidade de São Paulo. São Paulo: Instituto Saúde e Sustentabilidade. https://www. saudeesustentabilidade.org.br/wp-content/uploads/2017/05/GP_ISS_ Relatorio_ImpactosOnibusSP-1.pdf.

BCB (Banco Central do Brasil), 2018, "Taxas de juros." https://www.bcb. gov.br/estatisticas/txjuros.

Beelen, R., Raaschou-Nielsen, O., M. Stafoggia, Z.J. Andersen, G. Weinmayr B. Hoffmann, K. Wolf, et al., 2014. "Effects of Long-Term Exposure to Air Pollution on Natural-Cause Mortality: An Analysis of 22 European Cohorts within the Multicentre ESCAPE Project." Lancet 383 (9919): 785-95. https:// doi.org/10.1016/S0140-6736.

Booth, H., and L. Tickle. 2008. "Mortality Modelling and Forecasting: A Review of Methods." Annals of Actuarial Sciences 3 (1-2): 3-43. https://doi. org/10.1017/S1748499500000440.

Carriazo Osorio, F. 2001. "Impacts of Air Pollution on Property Values: An Economic Valuation for Bogotá, Colombia." Paper presented at the second workshop on Population, Economy and the Environment: Modeling and Simulating their Complex Interaction, Max Plant Institute for Demographic Research, Rostock, Germany, May 18-19. https://www.researchgate. net/publication/255659723_Impacts_of_Air_Pollution_on_Property_ Values_an_Economic_Valuation_for_Bogota_Colombia.

Cohen, A., M. Brauer, R. Burnett, R. Anderson, J. Frostad, K. Estep, K. Balakrishnan, B. Brunekreef, L. Dandona, R. Dandona, V. Feigin, G. Freedman, B. Hubbell, A. Jobling, H. Kan, L. Knibbs, Y. Liu, R. Martin, L. Morawska, C. Pope, H. Shin, K. Straif, G. Shaddick, M. Thomas, R. Van Dingenen, A. Van Donkelaar, T. Vos, C. Murray, and M. Forouzanfar. 2017. "Estimates and 25-Year Trends of the Global Burden of Disease Attributable to Ambient Air Pollution: An Analysis of Data from the Global
Burden of Diseases Study 2015." Lancet 389 (10082): 1907-18. https://doi. org/10.1016/S0140-6736(17)30505-6.

Conceição, G.M. de Souza, P.H.N. Saldiva, and J. da Motta Singer. 2001. "Modelos MLG e MAG para análise da associação entre poluição atmosférica e marcadores de morbi-mortalidade: Uma introdução baseada em dados da cidade de São Paulo." Revista Brasileira de Epidemiologia 4 (3): 206-19. http://dx.doi.org/10.1590/S1415790X2001000300007.

Costa, A.F., G. Hoek, B. Brunekreef, and A.C.M. Ponce de Leon. 2017, "Air Pollution and Deaths among Elderly Residents of São Paulo, Brazil: An Analysis of Mortality Displacement." Environmental Health Perspectives 125 (3): 349-54. https://www.ncbi.nlm.nih.gov/pmc/articles/PMC5332200/.

Detran SP (Departamento Estadual de Trânsito de São Paulo). 2019. "Frota de veículos em SP_por tipo de veículo," https://www.detran.sp.gov.br/ wps/wcm/connect/portaldetran/detran/detran/EstatisticasTransito/safrotaVeiculos/d28760f7-8f21-429f-b039-0547c8c46ed1?presentationtempl ate $=$ portaldetran\%2FAT-detranPaginaODetranImpressao.

EPA (U.S. Environmental Protection Agency). n.d. "Basic Information of Air Emissions Factors and Quantification." https://www.epa.gov/airemissions-factors-and-quantification/basic-information-air-emissionsfactors-and-quantification.

ExternE (External Costs of Energy). n.d. "The Impact Pathway Approach." http://www.externe.info/externe_d7/?q=node/46. Accessed December 2018.

Fairburn, J., S.A. Schüle, S. Dreger, L.K. Hilz, and G. Bolte. 2019. "Social Inequalities in Exposure to Ambient Air Pollution: A Systematic Review in the WHO European Region." International Journal of Environmental Research and Public Health 16 (17): E3127. https://doi.org/10.3390/ ijerph16173127.

Fajersztajn, L., P. Saldiva, L.A.A. Pereira, V.F. Leite, and A.M. Buehler. 2017. "Short-Term Effects of Fine Particulate Matter Pollution on Daily Health Events in Latin America: A Systematic Review and Metaanalysis." International Journal of Public Health 62 (7): 729-38. https://doi. org/10.1007/s00038-017-0960-y.

Freitas, S.R., K.M. Longo, M.F. Alonso, M. Pirre, V. Marecal, G. Grell, R. Stockler, R.F. Mello, and M. Sánchez Gácita. 2011. "PREP-CHEM-SRC-1.0: A Preprocessor of Trace Gas and Aerosol Emission Fields for Regional and Global Atmospheric Chemistry Models." Geoscientific Model Development 4 (2): 419-33. https://doi.org/10.5194/gmd-4-419-2011.

Fundação SEADE (Sistema Estadual de Análise de Dados Estatísticos). 2017. "Projeções demográficas 2050."June 26. http://visualizesp.seade.gov. br/tag/projecao-populacional/.

Fortin, P., C. Morency, M., Trépanier. "Innovative GTFS Data Application for Transit Network Analysis Using a Graph-Oriented Method. Journal of Public Transportation." 2016. https://scholarcommons.usf.edu/jpt/vol19/ iss $4 / 2$

Gevaerd, R., and S.R. Freitas. 2006. "Estimativa operacional da umidade do solo para inicialização de modelos de previsão numérica da atmosfera. Parte I: Descrição da metodologia e validação." Revista Brasileira de Meteorologia 21 (3): 1-15, 
Gouveia, N., F.P. Corrallo, A.C.P. de Leon, W. Junger, and C.U. de Freitas. 2017. "Air Pollution and Hospitalizations in the Largest Brazilian Metropolis." Revista de Saúde Pública 51 (December): 117. https://doi.org/10.11606/ S1518-8787.2017051000223.

Hettfleisch, K., L. Bernardes, M. Carvalho, L. Pastro, S. Vieira, S. Saldiva, P. Saldiva, and R. Francisco. 2017. "Short-Term Exposure to Urban Air Pollution and Influences on Placental Vascularization Indexes." Environmental Health Perspective 125 (4): 753-59. https://doi.org/10.1289/ EHP300,

Hooftman, N., L. Oliveira, M. Maarten, T. Coosemans, and J. Van Mierlo, 2016. "Environmental Analysis of Petrol, Diesel and Electric Passenger Cars in a Belgian Urban Setting." Energies 9 (2): 84. https://doi.org/10.3390/ en9020084.

IBGE (Instituto Brasileiro de Geografia e Estatística), 2010. "População residente por situação de domicílio, 2010." https://wwwibge.gov. br/estatisticas/sociais/saude/9662-censo-demografico-2010. $\mathrm{html}$ ?=\&t=destaques

IBGE. 2015. "Tabela 5795-Rendimento médio mensal nominal das pessoas de 15 anos ou mais de idade, com rendimento, por cor ou raça." Sistema IBGE de Recuperação Automática. https://sidra.ibge.gov.br/ tabela/5795

IBGE. 2017. "Produto interno bruto dos municípios." https://www.ibge.gov. br/estatisticas/economicas/contas-nacionais/9088-produto-internobruto-dos-municipios.html?=\&t=resultados.

IBGE, n.d.a. "Estimativas da População." https://www.ibge.gov.br/ estatisticas/sociais/populacao/9103-estimativas-de-populacao. $\mathrm{html}$ ?=\&t=0-que-e.

IBGE, n.d.b. "Índice Nacional de Preços ao Consumidor Amplo-IPCA." https://wwwibge.gov.br/estatisticas/economicas/precos-e-custos/9256indice-nacional-de-precos-ao-consumidor-amplo.html?=\&t=0-que-e.

Ignotti, E., S. de Souza Hacon, W.L. Junger, D. Mourão, K. Longo, S. Freitas, P. Artaxo, and A.C.M.P. de Leon. 2010. "Air Pollution and Hospital Admissions for Respiratory Diseases in the Subequatorial Amazon: A Time Series Approach." Cadernos de Saúde Pública 26 (4): 747-61. http://dx.doi. org/10.1590/S0102-311X2010000400017.

Karagulian, F., C. Belis, C. Dora, A. Prüss-Ustün, S. Bonjour, H. Adair-Rohani, and M. Amann. 2015. "Contributions to Cities' Ambient Particulate Matter (PM): A Systematic Review of Local Source Contributions at Global Level." Atmospheric Environment 120 (November): 475-83, https://doi. org/10.1016/j.atmosenv.2015.08.087.

Lichtenfels, A.J., J.B. Gomes, P.C. Pieri, S.G.E.K. Miraglia, J. Hallak, and P.H. Saldiva. 2007. "Increased levels of Air Pollution and a Decrease in the Human and Mouse Male-to-Female Ratio in Sao Paulo, Brazil." Fertility and Sterility 87: 230-40. https://doi.org/10.1016/j.fertnstert.2006.06.023.

Marcilio, I., and N. Gouveia. 2007. "Quantifying the Impact of Air Pollution on the Urban Population of Brazil." Cadernos de Saúde Pública 23 (4): S529-36. http://dx.doi.org/10.1590/S0102-311X2007001600013.

Martins, M.C.H., F.L. Fatigati, T.C. Véspoli, L.C. Martins, L.A.A. Pereira, M.A. Martins, P.H.N. Saldiva, and A.L.F. Braga. 2004. "Influence of Socioeconomic Conditions on Air Pollution Adverse Health Effects in Elderly People: An Analysis of Six Regions in São Paulo, Brazil." Journal of Epidemiology \& Community Health 58 (1): 41-6. https://doi.org/10.1136/jech.58.1.41.
Miraglia, S., N. Gouveia. 2014. "Costs of air pollution in Brazilian metropolitan regions." Ciência e saúde coletiva, 19 (10), 4141-4147.

Miraglia, S.G.E.K., M.M. Veras, L.F. Amato-Lourenço, F. Rodrigues-Silva, and P.H.N. Saldiva. 2013. "Follow-Up of the Air Pollution and the Human Male-to- Female Ratio Analysis in Sao Paulo, Brazil: A Times Series Study." British Medical Journal Open 3 (7): e002552. https://doi.org/10.1136/ bmjopen-2013-002552.

Miranda, R.M. de, M. de Fatima Andrade, A. Fornaro, R. Astolfo, P.A. de Andre, and P. Saldiva. 2012. "Urban Air Pollution: A Representative Survey of $\mathrm{PM}_{2.5}$ Mass Concentrations in Six Brazilian Cities." Air Quality, Atmosphere \& Health 5 (1): 63-77. https://doi.org/10.1007/s11869-010-0124-1,

MMA (Ministério do Meio Ambiente). 2011. Inventário nacional de emissões atmosféricas por veículos automotores rodoviários. Brasília: MMA. https://www.mma.gov.br/estruturas/163/_publicacao/163_ publicaca027072011055200.pdf

MMA. 2014. Inventário nacional de emissões atmosféricas por veículos automotores rodoviários. Brasília: MMA. http://www.mma.gov.br/ images/arquivo/80060/Inventario_de_Emissoes_por_Veiculos_ Rodoviarios_2013.pdf

Moreira, D.S., S.R. Freitas, J.P. Bonatti, L.M. Mercado, N.M.É, Rosário, K.M. Longo, J.B. Miller, M. Gloor, and L.V. Gatti. 2013. "Coupling between the JULES Land-Surface Scheme and the CCATT-BRAMS Atmospheric Chemistry Model (JULES-CCATT-BRAMS1.0): Applications to Numerical Weather Forecasting and the CO2 Budget in South America." Geoscientific Model Development 6 (4): 1243-59. https://doi.org/10.5194/gmd-6-1243-2013.

Nascimento, A.P. J.M. Santos, J.G. Mill, J.B. de Souza, N.C. Reis Júnior, and V.A. Reisen. 2016. "Association between the Concentration of Fine Particles in the Atmosphere and Acute Respiratory Diseases in Children." Revista de Saúde Pública 51:3. http://dx.doi.org/10.1590/s1518-8787.2017051006523.

National Research Council. 1988. Air Pollution, the Automobile, and Public Health. Washington, DC: National Academies Press. https://doi. org/10.17226/1033.

NTU (Associação Nacional das Empresas de Transportes Urbanos). 2020. "0 transporte público por ônibus em números: Cenário nacional." http:// www.ntu.org.br/novo/AreasInternas.aspx?idArea=7\&idSegundoNivel=107.

OECD (Organisation for Economic Co-operation and Development). 2012. Mortality Risk Valuation in Environment, Health and Transport Policies. Paris: OECD. http://dx.doi.org/10.1787/9789264130807-en.

OECD. 2014. The Cost of Air Pollution: Health Impacts of Road Transport. Paris: OECD.

Ortiz, R., A. Markandya, and A. Hunt. 2009. "Willingness to Pay for Mortality Risk Reduction Associated with Air Pollution in Sao Paulo," Revista Brasileira de Economia 63 (1): 3-22. http://dx.doi.org/10.1590/S003471402009000100001.

Ortiz, R.A., A. Hunt, R. Seroa da Motta, and V. MacKnight. 2011. "Morbidity Costs Associated with Ambient Air Pollution Exposure in Sao Paulo, Brazil." Atmospheric Pollution Research 2 (4): 520-29. https://doi.org/10.5094/ APR.2011.059. 
Ortiz-Durán, E.Y., and N.Y. Rojas-Roa. 2013، "Estimación de los beneficios económicos en salud asociados a la reducción de PM $_{10}$ en Bogotá." Revista de Salud Pública 15 (1): 90-102. https://revistas.unal.edu.co/index. php/revsaludpublica/article/view/38444/62074.

Pope, C., III. 2007. "Mortality Effects of Longer Term Exposures to Fine Particulate Air Pollution: Review of Recent Epidemiological Evidence." Journal of Inhalation Toxicology 19 (1): 133-38. https://doi. org/10.1080/08958370701492961.

Pope, C.A., III; and D. Dockery. 2006. "Health Effects of Fine Particulate Air Pollution: Lines that Connect." Journal of the Air \& Waste Management Association 56 (6): 709-42. https://doi.org/10.1080/10473289.2006.10464485,

Prefeitura da Cidade do Rio de Janeiro. 2018. "Balanço orçamentário." http://www.rio.rj.gov.br/dlstatic/10112/9568115/4236451/

Balanco0rcamentario.pdf.

Prefeitura do Município de São Paulo. 2018a. Demonstrativos consolidados (comparativos) e notas explicativas. São Paulo: Departamento de Contadoria, Prefeitura do Município de São Paulo. https://www. prefeitura.sp.gov.br/cidade/upload/02-demconsol-comparativos-notas_ explicativas-balanc02018_1552077569.pdf.

Prefeitura do Município de São Paulo. 2018b. "Lei No. 16.802, de 17 de Janeiro de 2018." LeisMunicipais, January 19. https://leismunicipais.com. br/a/sp/s/sao-paulo/lei-ordinaria/2018/1680/16802/lei-ordinaria-n-168022018-da-nova-redacao-ao-art-50-da-lei-n-14933-2009-que-dispoesobre-o-uso-de-fontes-motrizes-de-energia-menos-poluentes-e-menosgeradoras-de-gases-do-efeito-estufa-na-frota-de-transporte-coletivourbano-do-municipio-de-sao-paulo-e-da-outras-providencias.

Prefeitura Municipal de Belo Horizonte. 2018. "Demonstrativo da aplicação de recursos em ações e serviços públicos de saúde." https://prefeitura.pbh.gov.br/sites/default/files/estrutura-de-governo/ fazenda/Balan\%C3\%A70s/2018/12\%20-\%20Demonstrativ0\%20 da\%20Aplica\%C3\%A7\%C3\%A30\%20de\%20Recursos\%20em\%20 A\%C3\%A7\%C3\%B5es\%20e\%20Servi\%C3\%A7os\%20de\%20 Sa\%C3\%BAde.pdf.

Rivas, I., P. Kumar, and A. Hagen-Zanker. 2017. "Exposure to Air Pollutants During Commuting in London: Are There Inequalities among Different Socio-Economic Groups?" Environment International 101 (April): 143-57. https://doi.org/10.1016/j.envint.2017.01.019.

Rodrigues, P.C.O., S.I. Pinheiro, W. Junger, E. Ignotti, and S.S. Hacon. 2017. "Climatic Variability and Morbidity and Mortality Associated with Particulate Matter." Revista de Saúde Pública 51: 91. https://doi. org/10.11606/S1518-8787.2017051006952.

Rodrigues-Silva, F., U. de Paula Santos, P.H.N. Saldiva, L.F. AmatoLourenço, and S.G.E.K. Miraglia. 2012. "Health Risks and Economic Costs of Absenteeism Due to Air Pollution in São Paulo, Brazil." Aerosol and Air Quality Research 12: 826-33. https://doi.org/10.4209/aaqr.2011.12,0235.

Rosen, S., and T. Gayer. 2008. Public Finance. 8th ed. Boston: McGraw-Hill Irwin.

Roy, R. 2016. "The Cost of Air Pollution in Africa." OECD Development Centre Working Paper 333, 0ECD, Paris, http://dx.doi.org/10.1787/5jlqzq77x6f8-en.

Roy, R., and N. Braathen. 2017. "The Rising Cost of Ambient Air Pollution thus far in the 21st Century: Results from the BRIICS and the OECD
Countries." OECD Environment Working Paper 124, OECD, Paris, https://doi. org/10.1787/d1b2b844-en.

Sclar, R., C. Gorguinpour, S. Castellanos, and X. Li. 2019. Barriers to Adopting Electric Buses. Washington, DC: World Resources Institute. https://www. wri.org/publication/barriers-adopting-electric-buses.

Silva, L.T. da, K.C. Abe, and S.G.E.K Miraglia. 2017. "Avaliação de impacto à saúde da poluição do ar no município de Diadema, Brasil." Revista Brasileira de Ciências Ambientais 46: 117-29. https://doi.org/10.5327/Z2176947820170258.

SMU (Secretário Municipal de Urbanismo e Mobilidade). 2015. Revisão do Plano Diretor de Niterói. Niterói: Prefeiture Niterói Urbanismo e Mobilidade. http://urbanismo.niteroi.rj.gov.br/wp-content/uploads/2015/09/PDDU_ CENARIOS_APRESENTACA0-AUDIENCIAS-PUBLICAS.pdf.

SPTrans (São Paulo Transporte), 2012. "Livo ecofrota." https://www. slideshare.net/trans_smt//ivro-ecofrota?from_action=save.

Stoeldraijer, L., C. van Duin, L. van Wissen, and F. Janssen. 2013 "Impact of Different Mortality Forecasting Methods and Explicit Assumptions on Projected Future Life Expectancy: The Case of the Netherlands." Demographic Research 29 (13): 323-54. https://doi.org/10.4054/ DemRes.2013.29.13.

UNEP (United Nations Environment Programme), 2011. Near-Term Climate Protection and Clean Air Benefits: Actions for Controlling Short-Lived Climate Forcers: A UNEP Synthesis Report. Nairobi: UNEP. http://hdl.handle. net/20.500.11822/8048.

Urvashi, N., and C. Sall. 2016. Methodology for Valuing the Health Impacts of Air Pollution: Discussion of Challenges and Proposed Solutions. Washington DC: World Bank Group. http://documents.worldbank.org/ curated/en/832141466999681767/Methodology-for-valuing-the-healthimpacts-of-air-pollution-discussion-of-challenges-and-proposedsolutions.

Watt, J., J. Tidblad, V. Kucera, and R. Hamilton. eds. 2009. The Effects of Air Pollution on Cultural Heritage. Boston: Springer.

WHO (World Health Organization). 2016. Ambient Air Pollution: A Global Assessment of Exposure and Burden of Disease. Geneva: WHO. https:// apps.who.int/iris/handle/10665/250141.

WHO. 2018, "Ambient (Outdoor) Air Quality and Health." May 2. https:// www.who.int/news-room/fact-sheets/detail/ambient-(outdoor)-airquality-and-health.

WHO/Europe (World Health Organization Regional Office for Europe) and OECD (Organisation for Economic Co-operation and Development). 2015. Economic Cost of the Health Impact of Air Pollution in Europe: Clean Air, Health and Wealth. Copenhagen: WHO/Europe.

World Bank and IHME (Institute for Health Metrics and Evaluation). 2016. The Cost of Air Pollution: Strengthening the Economic Case for Action. Washington, DC: World Bank. http://documents.worldbank.org/curated/ en/781521473177013155/The-cost-of-air-pollution-strengthening-theeconomic-case-for-action.

Yanagi, Y., J.V. Assunção, and L.V. Barrozo. 2012. "The Impact of Atmospheric Particulate Matter on Cancer Incidence and Mortality in the City of São Paulo, Brazil." Cadernos de Saúde Pública 28 (9): 1737-48. https://doi. org/10.1590/s0102-311×2012000900012. 


\section{ACKNOWLEDGMENTS}

WRI Brasil developed the Valuation Tool for Health Impacts of Air Pollution (ImpactAr) with the financial support of the Children's Investment Fund Foundation (CIFF).

We express our sincere gratitude to the following individuals for the technical expertise they provided: Marcelo Félix Alonso (UFPel), Ely José de Mattos (PUCRS), and Jonas da Costa Carvalho (UFPel).

Our acknowledgments to those who contributed directly or indirectly to the implementation of this project: Rachel Biderman, Luís Antônio Lindau, Rafael Barbieri, Talita Esturba, and Luiza de Oliveira Schmidt.

Thanks also to the internal and external reviewers: Ajay Singh Nagpure, Anne Dorothée Slovic, Arya Harsono, Guillermo Petzhold, Heloant Souza, Matt Whitney, Ronaldo Serôa da Motta, Seth Contreras, Washington Junger, and Walter de Simoni.

\section{ABOUT THE AUTHORS}

Luana Priscila Betti is the Urban Economics Coordinator at WRI Brasil.

Contact: luana.betti@wri.org

Marina Caregnato Garcia is an Urban Economics Analyst at WRI Brasil.

Contact: marina.garcia@wri.org

Eduardo Siqueira is an Urban Mobility Analyst at WRI Brasil.

Contact: eduardo.siqueira@wri.org

Henrique Evers is the Urban Development Manager at WRI Brasil.

Contact: henrique.evers@wri.org

\section{ABOUT WRI BRASIL}

WRI Brasil is a research institute that transforms big ideas into actions to protect the environment and foster Brazil's prosperity in an inclusive and sustainable fashion. It is focused on research and applications of sustainable solutions oriented towards climate, forests, and cities. WRI Brasil combines technical excellence with political articulation and works in close collaboration with governments, private companies, universities and civil society.

WRI Brasil is part of World Resources Institute (WRI), a global research organization whose work extends to over 50 countries. WRI encompasses the work of almost 1000 professionals in offices in Brazil, China, the United States, Mexico, India, Indonesia, Europe, Turkey and Africa.

\section{ABOUT CIFF}

The Children's Investment Fund Foundation (CIFF) is an independent philanthropic organization with offices in Addis Ababa, Beijing, London, Nairobi, and New Delhi. Established in 2003, CIFF works with a wide range of partners seeking to transform the lives of children and adolescents across the world. CIFF's areas of work include maternal and child health, adolescent sexual health, nutrition, education and income generation, child protection, and supporting smart ways to slow down and stop climate change.

CHILDREN'S

INVESTMENT FUND FOUNDATION 